\title{
The Impact Of Latino-Owned Business On Local Economic Performance
}

by

\author{
Craig Wesley Carpenter \\ Department of Agricultural Economics \\ Texas A\&M University
}

\begin{abstract}
CES 16-34
July, 2016

The research program of the Center for Economic Studies (CES) produces a wide range of economic analyses to improve the statistical programs of the U.S. Census Bureau. Many of these analyses take the form of CES research papers. The papers have not undergone the review accorded Census Bureau publications and no endorsement should be inferred. Any opinions and conclusions expressed herein are those of the author(s) and do not necessarily represent the views of the U.S. Census Bureau. All results have been reviewed to ensure that no confidential information is disclosed. Republication in whole or part must be cleared with the authors.

To obtain information about the series, see www.census.gov/ces or contact J. David Brown, Editor, Discussion Papers, U.S. Census Bureau, Center for Economic Studies 5K034A, 4600 Silver Hill Road, Washington, DC 20233, CES.Papers.List@census.gov. To subscribe to the series, please click here.
\end{abstract}




\begin{abstract}
This paper takes advantage of the Michigan Census Research Data Center to merge limitedaccess Census Bureau data with county level information to investigate the impact of Latinoowned business (LOB) employment share on local economic performance measures, namely per capita income, employment, poverty, and population growth. Beginning with OLS and then moving to the Spatial Durbin Model, this paper shows the impact of LOB overall employment share is insignificant. When decomposed into various industries, however, LOB employment share does have a significant impact on economic performance measures. Significance varies by industry, but the results support a divide in the impact of LOB employment share in low and high-barrier industries.
\end{abstract}

\footnotetext{
*Thanks to Anil Rupasingha, Myriam Quispe-Agnoli, Melissa Banzhaf, J. Clint Carter, Margaret Leventsin, and the Interuniversity Consortium for Political and Social Research for their assistance with the RDC process. Support for this research at the Michigan RDC from NSF (ITR-0427889), Scott Loveridge, the North Central Regional Center for Rural Development, and the Department of Agricultural, Food, and Resource Economics at Michigan State University is also gratefully acknowledged. Any opinions and conclusions expressed herein are those of the author and do not necessarily represent the views of the U.S. Census Bureau. All results have been reviewed to ensure that no confidential information is disclosed. Department of Agricultural Economics, Texas A\&M University, 600 John Kimbrough Blvd., College Station, TX 77843-2124. ccarpenter@tamu.edu
} 


\section{Introduction}

Small business development in the U.S. by minorities and immigrant groups is of special economic interest for a number of reasons. Self-employment has been proposed as a viable alternative to formal wage and salary employment, especially for individuals who may have difficulty breaking into the formal employment market. Business formation among ethnic minorities and women has been cited as a tool to promote equal economic opportunities in communities and a principal means for new immigrants to adopt and survive economically (Mar 2005). Minority-owned businesses are an integral component of recent popular local economic development strategies commonly known as economic gardening, grow your own, and locally based entrepreneurship.

Despite the calls for promoting ethnic and immigrant-owned business as a local development strategy to create income and employment, to alleviate poverty, and to discourage population loss, less is known about the contributions of such businesses in general, and Latinoowned business (LOB) in particular, to economic performance at the local level in the U.S. Although some studies have examined the impact of LOB at the local level (Grey 2006; Robles and Zarnikau 2004), there are few attempts at comprehensive examinations of the impact of LOB overall in the United States. Latinos are the largest immigrant group, and one of the largest ethnic groups in the United States (Robles and Cordero-Guzmán. 2007). The objective of this paper is to address this problem and provide research findings that inform decision makers and practitioners on the effects of LOB on local economic performance. 


\section{Literature Review}

Although past research examined the impact of immigration on measures of economic performance (Massey 1993, Zhou 2004) and other research examined the relative success of different ethnic groups in self-employment (e.g., Borjas 1990, Fairlie and Robb 2008), there is a dearth of research into the impact of employment by various ethnic groups on measures of economic success. This relative lack of research is despite the calls for promoting minorityowned businesses as a local development strategy to create income and employment, to alleviate poverty, and to discourage population loss. There is a need for better information about the contributions minority-owned businesses in general and Latino-owned business (LOB) in particular to economic performance at the local level in the U.S.

Relative to other ethnicities, Latinos concentrate in relatively vulnerable sectors, such as lower-order services (Puryear et al. 2008, Robles and Cordero-Guzmán 2007), construction, wholesale trade, and retail trade sectors (U.S. Census Bureau 2010). Martinez et al. (2011) explain LOB are often associated with low-barrier industries because they lack financial capital to enter high-barrier industries. High barrier industries are industries that require at least a bachelor's degree (often higher) or a large amount startup capital. High barrier industries include professional services, and finance or insurance. Low barrier industries include some food services and construction. Past research found that business owners with large amounts of personal capital to spend on business startup will open more lucrative businesses in high-barrier industries, while others experience lower growth in the relatively vulnerable low-barrier industries (Bates, Lofstrom, and Servnon 2010). Given this relationship, one would expect a divide between the impact of LOB employment share in high and low-barrier industries on local economic growth. 
The impact of LOB employment share on population growth relates to another stream of literature on immigrant and native flows. Although this paper does not specify that persons making up the LOB employment share must be immigrants, over 1 in 3 Latinos in the U.S. are immigrants (Zong and Batalova 2015). Card and DiNardo (2000) find that immigrant inflows do not imply selective out-migration by natives. This paper will extend their work by breaking down this overall effect by industry share. This paper will also examine the validity of the distance dependence of mobility, in which large concentrations of immigrants in surrounding areas reduce native out-mobility (Crowder et al. 2011). Finally, it is important to emphasize that Latino workers and LOB in the United States are not a monolithic group of low-wage migrants (Zarrugh 2007). This paper expands on past research by specifically breaking down that impact of LOB by industry, while controlling for local business owner characteristics. This paper begins its examination with equation-by-equation OLS and then moves to a Spatial Durbin Model. The results show that the impact of LOB overall employment share is insignificant, but that, when decomposed by industry, LOB employment share does have significant impacts on economic performance measures. Significance varies by industry, but the results support the aforementioned divide in the impact of LOB employment share in low and high-barrier industries.

A problem with much regional growth literature, especially when examining local economic performance, is the existence of spatial spillover effects. When using data sets composed of observations on smaller geographic areas such as counties, the economic changes in one locality may have spillover effects on neighboring areas, creating a pattern of spatial dependence that requires a spatial econometric approach to prevent biased results. Previous studies using United States county- and state-level data have confirmed that county-level cross 
sectional data display spatial dependence (Rey and Montouri 1999; Rupasingha et al. 2002; Rey and Janikas 2005). There are competing spatial models to address various forms of spatial dependence. Specifically, some studies consider only spatial dependence in the dependent variable using spatial lag model or SAR and others examine only spatial dependence in the error term using spatial error model or SEM (Abreu et al. 2004). Abreu et al. (2004) also refer to studies that use both, error and lag dependence, in the same model using general spatial model as well as spatial dependence in the independent variables. LeSage and Fischer (2008) suggest that the appropriate spatial regression model for regional growth regressions such as the regressions included herein is the Spatial Durbin Model (SDM) because the spatial spillover effects of economic performance variables are global in nature.

\section{Methods}

Thus this paper will use the following methods to investigate these five hypotheses:

H1. LOB employment share has a positive impact on the local economic performance measures.

H2. LOB employment share in low-barrier industries has a negative impact on the local economic performance measures.

H3. LOB employment share in high-barrier industries has a positive impact on the local economic performance measures.

H4. Immigrant inflows do not imply selective out-migration by natives.

H5. Large concentrations of immigrants in surrounding areas reduce native out-mobility. 
The objective of this paper is to investigate the effects of LOB on the economic performance of U.S. counties. As mentioned above, I measure local economic performance using per capita income growth, employment growth, the change in poverty, and population growth using publicly available county-level data as described below. The analytical framework for this objective is based on a conditional convergence approach (Barro 1998), which is derived from the neoclassical growth model. The neoclassical growth model assumes that the per capita growth rate in a country or region tends to be inversely related to the starting levels of output or income level (Barro and Sala-i-Martin 1992) and suggests that poorer economies should grow faster than richer economies. According to the model, poor economies should eventually "catch up" based on the assumption of decreasing returns to capital, which should cause more advanced economies to grow more slowly than less advanced ones.

To evaluate the relationship between Latino business ownership and economic performance, I use the following regression equation at the county-level:

(7) $\quad g_{(t-\tau, t), i}=\alpha_{i}+\beta y_{t-\tau, i}+\gamma L O B_{t-\tau, i}+\delta X_{t-\tau, i}+\varepsilon_{i t}$ where $g_{(t-\tau, t), i}$ is the average dependent variable under consideration for county $i$ from period $t-\tau$ to $t$, where $\tau$ represents the length of time period, $y_{t^{-} \tau, i}$ is the convergence variable (initial per capita income, initial employment, initial poverty rate, and initial population), $X_{t^{-} \tau, i}$ is a vector of other initial conditions and $\varepsilon_{i t}$ is the error term. For the dependent variables, I use the time period between 2000 and 2010. Since these are growth (or change) variables, I calculate the change between the two time periods using 2000 as the base year (except for poverty rate) and then average the growth rate over the time. For the change in poverty rate, I take the difference between the poverty rate for 2000 and 2010. Per capita income and employment growth are 
measured using external Bureau of Economic Analysis (BEA) county-level data and change in poverty and population growth rate is measured using external Bureau of the Census data.

The variable of interest in this estimation is LOB and hypothesized to be positively associated with growth in income, employment, and population and negatively associated with change in poverty rate. I test both the share of employment by LOB in 2002 and the change of this share between 2002 and 2007. I further expand the examination of the impact of Latino business ownership by examining the impact of LOB employment share in each NAICS 2-digit industry code. In this latter specification, LOB is a vector of LOB employment share under each 2-digit NAICS code. The standard county-level control variables used in the regional growth literature include percent of people who have various levels of education as a proxy for human capital, local government taxes per capita, and expenditures on education and highways as government variables, minority populations to capture labor market trends, population density as an agglomeration variable, and natural amenities. All these controls are available from external data sources.

This paper initially estimates the growth model using equation-by-equation OLS. But econometric models for both determinants and effects of LOB must account for potential estimation issues. For example both LOB activity and our measures of economic performance in counties have common elements that drive underlying dynamics of these variables. Because of this, it is highly likely that LOB activities and regional economic performance (income and employment growth, poverty, and population change) are endogenously determined. In other words, the estimates could reflect some degree of reverse causality or spurious correlation. Therefore, the models must test for endogeneity bias and correct the bias (if there is any) by appropriate estimation procedures. The estimation strategy must also account for possible 
endogeneity bias in other independent variables. To mitigate this issue, I lag values of all independent variables, to determine the extent to which any relationship between LOB and local economic performance indicators is causal. This "weakly exogenous” approach (Levine et al. 2000) assumes that future growth rates of our dependent variables do not affect current levels of explanatory variables. The model measures all right-hand-side variables at the beginning year, which is 2000 or around 2000, and all growth variables for the period between 2000 and 2010. Another potential estimation issue in the local economic performance regressions may be the existence of spatial spillover effects. Using data sets composed of observations on smaller geographic areas such as counties, the economic changes in one locality may have spillover effects on neighboring areas, creating a pattern of spatial dependence that requires a spatial econometric approach. Previous studies using U.S. county- and state-level data have confirmed that these regional cross sectional data display spatial dependence (Rey and Montouri 1999; Rupasingha et al. 2002; Rey and Janikas 2005). Previous growth studies have used competing spatial models to address various forms of spatial dependence. For example, some studies consider only spatial dependence in the dependent variable using spatial lag model or SAR and others examine only spatial dependence in the error term using spatial error model or SEM (Abreu et al. 2004). Abreu et al. (2004) also refer to studies that use both, error and lag dependence, in the same model using general spatial model as well as spatial dependence in the independent variables. LeSage and Fischer (2008) suggest that the appropriate spatial regression model for regional growth regressions such as the following regressions is the Spatial Durbin Model because the spatial spillover effects of our economic performance variables are global. The Spatial Durbin Model (SDM) includes a spatial lag of the dependent variable as well as spatial lags of the explanatory variables. 
The SDM for this growth model can be written as:

$$
\begin{array}{r}
g_{i}=\rho W g_{i}+\theta W X_{i}+\beta X_{i}+\alpha_{i}+\varepsilon \\
\varepsilon \sim N\left(0, \sigma^{2} I\right)
\end{array}
$$

where $g_{i}$ denotes an $n x 1$ vector of the dependent variable in equation (2), $X_{i}$ represents an $n x k$ matrix containing the determinants of the dependent variable including the LOB and convergence variables and $W$ is an $n x n$ inverse-distance spatial weighting matrix, such that the

elements of $W, w_{i j}=\frac{1}{d_{i j}}$, where $d_{i j}$ is the distance between the centroids of counties $i$ and $j$. Other specifications of the weighting matrix, including the nearest neighbor specification, produce similar results and thus not included here for sake of readability. The terms $\rho W g_{i}$ and $\theta W X_{i}$ in the equation add dependent variable and explanatory variables respectively from neighboring counties. $\rho, \beta$, and $\theta$ denote the parameters to be estimated. The coefficients $\rho$ and $\theta$ estimate the extent to which the dependent and independent variables of nearby counties influence economic performance in the original county.

\section{Data}

The data result from merging three restricted access Census Bureau data sets by individual firm and establishment level. The three databases are the Integrated Longitudinal Business Database (ILBD), the Longitudinal Business Database (LBD) and the Survey of Business Owners (SBO). Researchers can only access these datasets within a Census RDC and if they have an approved project. To further examine the effects of these businesses on local economic performance, the data links merged ILBD-LBD and SBO data with publicly available 
county-level data from Bureau of the Census, Bureau of Economic Analysis (BEA) and the U.S. Department of Agriculture (USDA).

Factors associated with LOB ownership and dynamics include characteristics of business and industry, characteristics of business owner, and characteristics of location. The standard economic model predicts that these factors are associated with the firm's production process. While measures of business ownership are available from the SBO, the data are cross-sectional and cannot capture the dynamics of LOB. Measures of business creation, expansion, and destruction are needed to represent dynamics of businesses. Such measures are available from the LBD or can be created using the LBD. On the other hand, the LBD lacks information on the characteristics of business owners such as race, ethnicity, gender, education level, whether the owner is foreign born, and access to capital. Such information is available from the SBO.

Further, the LBD is at the establishment level, whereas the SBO is at the firm level. However, the LBD has a firm identifier, making the linking of the LBD with the SBO feasible by firm identifier. The ILBD is needed to address the issue that while SBO has information about firms that have no paid employees, the LBD has information only about establishments that have paid employees. The ILBD consists of administrative records for all nonemployer business units. By linking the ILBD, LBD, and SBO, one can track the dynamics of not only employer LOB but also the nonemployer LOB including the transitions of LOB nonemployers to LOB employers. Although location of the businesses are available from these merged data sets, location specific characteristics such as agglomeration, racial make-up of location, amenities, and market size are not available in this data. This requires linking merged data with location specific factors that are publicly available from the Bureau of the Census, the BEA and the USDA. The investigation of 
the effects of LOB on local economic performance requires aggregating LOB firm outcomes at the county-level and then merging with publicly available data.

To analyze Latino-owned businesses and county economic performance, this paper tests the effects of the share of employment by LOB and the growth of this share between 2002 and 2007 on county economic performance measures, namely income and employment growth, changes in poverty, and population growth. This paper uses the so-called "labor market approach” to calculate the LOB employment variables (Acs and Armington 2004). First, I calculate the total employment by all the businesses in a county using merged data sets (SBO with ILBD/LBD) for the year 2002. Next I calculate the total employment by LOB for 2002 using the same merged data and then calculate the ratio of employment by LOB as a percent of total employment, which the model assumes to approximate the county-level share of private employment by LOB. I also calculate the same share for 2007 and then take the difference in the share between 2002 and 2007 to calculate the change of employment by LOB over time. ${ }^{3}$ My study period for this analysis is between 2000 and 2010 and dependent variables (income and employment growth, changes in poverty, and population growth) is calculated for this time period using data from external data sources. ${ }^{4}$ All the other control variables (or initial conditions in a growth framework) are measured at 2000 or close to that year depending on data availability from external sources.

Although some form of the SBO is available since 1982, many of these earlier surveys are not as comprehensive as the ones for 2002 and 2007. For example, one of the most important

\footnotetext{
${ }^{3}$ Since the SBO is a stratified sample of firms based on racial/ethnic status of the owner, the model uses the SBO weights to make sure LOB employment ratio at the county level is representative of the firm population.

${ }^{4}$ The ending year for the growth/change period is 2010 due to the unavailability of population and poverty data prior to the 2010 decennial Census. Although annual data are available for income and employment variables, this paper uses 2010 for them also to be consistent with the data selection for population and poverty variables.
} 
questions on sources of capital was not asked in the surveys prior to 2002. Therefore, for the matching purposes I use the years 2002 and 2007 of SBO data and annual ILBD and LBD data from 1994-2007 data. The matched data contains detailed information from the LBD on establishment openings and closing, jobs creation, expansion, contraction, and destruction of businesses and from the SBO the business owner characteristics and additional firm characteristics. Although the age and size of the firm can be traced roughly using SBO data, this paper uses a more precise measure that is available in the previous literature (Davis et al. 2007; Haltiwanger et al. 2010) to identify firm dynamics including new firm formation using the LBD.

\section{Results}

The results of the equation-by-equation OLS regressions of the growth in the four measures of economic performance between 2000 and 2010 on Latino employment share growth between 2002 and 2007 are given in Table 8. This regression controls for county-level industry employment, industry establishment counts, and state indicator variables, but their coefficients are given in the appendix Table A6 for readability. As it is likely that the LOB employment share growth between 2002 and 2007 is endogenously determined with measures of economic

performance, this paper briefly discusses these results, but focuses on the impact of the base share of LOB employment, rather than the contemporaneous growth in that share. 
Table 8. OLS Regressions of Economic Performance on LOB Employment Share Growth

\begin{tabular}{|c|c|c|c|c|}
\hline & $\begin{array}{c}\text { (1) } \\
\text { Income } \\
\text { Growth Rate }\end{array}$ & $\begin{array}{l}\text { (2) } \\
\text { Employment } \\
\text { Growth Rate }\end{array}$ & $\begin{array}{c}\text { (3) } \\
\text { Poverty Rate } \\
\text { Growth }\end{array}$ & $\begin{array}{c}\text { (4) } \\
\text { Population } \\
\text { Growth Rate }\end{array}$ \\
\hline LOB share growth & $\begin{array}{c}0.01 \\
(0.06)\end{array}$ & $\begin{array}{c}0.03 \\
(0.06)\end{array}$ & $\begin{array}{c}0.01 \\
(0.04)\end{array}$ & $\begin{array}{l}-0.01 \\
(0.04)\end{array}$ \\
\hline Per capita income & $\begin{array}{c}-0.00 * * * \\
(0.00)\end{array}$ & $\begin{array}{c}-0.00 * * * \\
(0.00)\end{array}$ & $\begin{array}{c}-0.00 * * * \\
(0.00)\end{array}$ & $\begin{array}{l}-0.00 * \\
(0.00)\end{array}$ \\
\hline Employment & $\begin{array}{l}-0.00 \\
(0.00)\end{array}$ & $\begin{array}{c}-0.00 * * * \\
(0.00)\end{array}$ & $\begin{array}{c}0.00 * * \\
(0.00)\end{array}$ & $\begin{array}{l}-0.00 \\
(0.00)\end{array}$ \\
\hline Poverty rate & $\begin{array}{c}0.30^{* * * *} \\
(0.08)\end{array}$ & $\begin{array}{l}-0.05 \\
(0.09)\end{array}$ & $\begin{array}{c}-0.48^{* * *} \\
(0.03)\end{array}$ & $\begin{array}{l}-0.14^{*} \\
(0.07)\end{array}$ \\
\hline Population & $\begin{array}{c}0.00 \\
(0.00)\end{array}$ & $\begin{array}{l}-0.00 \\
(0.00)\end{array}$ & $\begin{array}{c}-0.00 * * * \\
(0.00)\end{array}$ & $\begin{array}{c}-0.00^{* *} \\
(0.00)\end{array}$ \\
\hline Population squared & $\begin{array}{l}-0.00 \\
(0.00)\end{array}$ & $\begin{array}{l}-0.00 \\
(0.00)\end{array}$ & $\begin{array}{c}0.00^{* * *} \\
(0.00)\end{array}$ & $\begin{array}{l}-0.00 \\
(0.00)\end{array}$ \\
\hline Population density & $\begin{array}{c}0.00 * * \\
(0.00)\end{array}$ & $\begin{array}{l}-0.00 \\
(0.00)\end{array}$ & $\begin{array}{l}-0.00 \\
(0.00)\end{array}$ & $\begin{array}{l}-0.00^{*} \\
(0.00)\end{array}$ \\
\hline Average household size & $\begin{array}{c}0.10^{* * *} \\
(0.02)\end{array}$ & $\begin{array}{c}0.13^{* * *} \\
(0.02)\end{array}$ & $\begin{array}{l}-0.00 \\
(0.01)\end{array}$ & $\begin{array}{c}0.05 * * * \\
(0.02)\end{array}$ \\
\hline \% headed by single female & $\begin{array}{c}-0.59 * * * \\
(0.08)\end{array}$ & $\begin{array}{c}-0.40 * * * \\
(0.09)\end{array}$ & $\begin{array}{c}0.30 * * * \\
(0.03)\end{array}$ & $\begin{array}{c}-0.48^{* * *} \\
(0.07)\end{array}$ \\
\hline Median age & $\begin{array}{c}0.03 * * * \\
(0.01)\end{array}$ & $\begin{array}{l}-0.01 * \\
(0.01)\end{array}$ & $\begin{array}{c}-0.01 * * * \\
(0.00)\end{array}$ & $\begin{array}{l}-0.01 \\
(0.01)\end{array}$ \\
\hline Median age squared & $\begin{array}{c}-0.00 * * * \\
(0.00)\end{array}$ & $\begin{array}{l}0.00 * \\
(0.00)\end{array}$ & $\begin{array}{c}0.00 * * * \\
(0.00)\end{array}$ & $\begin{array}{c}0.00 \\
(0.00)\end{array}$ \\
\hline Female population & $\begin{array}{l}-0.00 \\
(0.00)\end{array}$ & $\begin{array}{l}0.00 * \\
(0.00)\end{array}$ & $\begin{array}{c}0.00 * * * \\
(0.00)\end{array}$ & $\begin{array}{c}0.00 * * \\
(0.00)\end{array}$ \\
\hline Female population squared & $\begin{array}{c}0.00 \\
(0.00)\end{array}$ & $\begin{array}{c}0.00 \\
(0.00)\end{array}$ & $\begin{array}{c}-0.00 * * * \\
(0.00)\end{array}$ & $\begin{array}{c}0.00 \\
(0.00)\end{array}$ \\
\hline Asian population & $\begin{array}{l}-0.00 \\
(0.00)\end{array}$ & $\begin{array}{c}0.00 \\
(0.00)\end{array}$ & $\begin{array}{c}0.00 \\
(0.00)\end{array}$ & $\begin{array}{c}0.00 \\
(0.00)\end{array}$ \\
\hline Asian population squared & $\begin{array}{c}0.00 \\
(0.00)\end{array}$ & $\begin{array}{c}0.00 \\
(0.00)\end{array}$ & $\begin{array}{c}0.00 \\
(0.00)\end{array}$ & $\begin{array}{c}0.00 \\
(0.00)\end{array}$ \\
\hline Black population & $\begin{array}{l}-0.00 \\
(0.00)\end{array}$ & $\begin{array}{l}-0.00 * \\
(0.00)\end{array}$ & $\begin{array}{c}-0.00 * * * \\
(0.00)\end{array}$ & $\begin{array}{c}-0.00 * * * \\
(0.00)\end{array}$ \\
\hline Black population squared & $\begin{array}{l}-0.00 \\
(0.00)\end{array}$ & $\begin{array}{c}0.00 \\
(0.00)\end{array}$ & $\begin{array}{c}0.00^{* * * *} \\
(0.00)\end{array}$ & $\begin{array}{c}0.00 * * \\
(0.00)\end{array}$ \\
\hline Hispanic population & $\begin{array}{c}-0.00^{* *} \\
(0.00)\end{array}$ & $\begin{array}{c}0.00 \\
(0.00)\end{array}$ & $\begin{array}{l}0.00 * \\
(0.00)\end{array}$ & $\begin{array}{l}0.00 * \\
(0.00)\end{array}$ \\
\hline Hispanic population squared & $\begin{array}{l}-0.00 \\
(0.00)\end{array}$ & $\begin{array}{l}-0.00 \\
(0.00)\end{array}$ & $\begin{array}{c}0.00 \\
(0.00)\end{array}$ & $\begin{array}{c}0.00 \\
(0.00)\end{array}$ \\
\hline Median age & $\begin{array}{c}0.03^{* * * *} \\
(0.01)\end{array}$ & $\begin{array}{l}-0.01 * \\
(0.01)\end{array}$ & $\begin{array}{c}-0.01^{* * *} \\
(0.00)\end{array}$ & $\begin{array}{l}-0.01 \\
(0.01)\end{array}$ \\
\hline
\end{tabular}


Table 8. (cont'd)

\begin{tabular}{|c|c|c|c|c|}
\hline & $\begin{array}{c}\text { (1) } \\
\text { Income } \\
\text { Growth Rate }\end{array}$ & $\begin{array}{l}\qquad(2) \\
\text { Employment } \\
\text { Growth Rate }\end{array}$ & $\begin{array}{c}\text { (3) } \\
\text { Poverty Rate } \\
\text { Growth }\end{array}$ & $\begin{array}{c}\text { (4) } \\
\text { Population } \\
\text { Growth Rate }\end{array}$ \\
\hline \% with education: high school & $\begin{array}{c}0.32 * * * \\
(0.07)\end{array}$ & $\begin{array}{l}0.12 * \\
(0.07)\end{array}$ & $\begin{array}{c}-0.08 * * * \\
(0.02)\end{array}$ & $\begin{array}{c}0.04 \\
(0.05)\end{array}$ \\
\hline Some college & $\begin{array}{c}0.37 * * * \\
(0.08)\end{array}$ & $\begin{array}{c}0.23^{* * *} \\
(0.09)\end{array}$ & $\begin{array}{c}-0.08 * * * \\
(0.03)\end{array}$ & $\begin{array}{c}0.19 * * * \\
(0.07)\end{array}$ \\
\hline Associates degree & $\begin{array}{c}0.75 * * * \\
(0.16)\end{array}$ & $\begin{array}{c}0.17 \\
(0.15)\end{array}$ & $\begin{array}{c}-0.21 * * * \\
(0.05)\end{array}$ & $\begin{array}{l}-0.19 \\
(0.12)\end{array}$ \\
\hline Bachelor's degree & $\begin{array}{c}0.78 * * * \\
(0.12)\end{array}$ & $\begin{array}{c}0.58^{* * * *} \\
(0.13)\end{array}$ & $\begin{array}{c}-0.11^{* * *} \\
(0.03)\end{array}$ & $\begin{array}{c}0.35 * * * \\
(0.14)\end{array}$ \\
\hline graduate school degree & $\begin{array}{c}0.69 * * * \\
(0.15)\end{array}$ & $\begin{array}{c}0.21 \\
(0.19)\end{array}$ & $\begin{array}{l}0.08 * \\
(0.05)\end{array}$ & $\begin{array}{c}0.14 \\
(0.15)\end{array}$ \\
\hline Taxes per capita & $\begin{array}{l}-0.00 * \\
(0.00)\end{array}$ & $\begin{array}{l}-0.00 \\
(0.00)\end{array}$ & $\begin{array}{c}0.00 \\
(0.00)\end{array}$ & $\begin{array}{l}-0.00 \\
(0.00)\end{array}$ \\
\hline Education spending & $\begin{array}{l}-0.00 \\
(0.00)\end{array}$ & $\begin{array}{c}0.00 \\
(0.00)\end{array}$ & $\begin{array}{c}0.00 \\
(0.00)\end{array}$ & $\begin{array}{l}-0.00 \\
(0.00)\end{array}$ \\
\hline Highway spending & $\begin{array}{c}0.00 \\
(0.00)\end{array}$ & $\begin{array}{l}-0.00 \\
(0.00)\end{array}$ & $\begin{array}{l}-0.00 \\
(0.00)\end{array}$ & $\begin{array}{c}0.00 \\
(0.00)\end{array}$ \\
\hline Build permits & $\begin{array}{c}-0.00 * * \\
(0.00)\end{array}$ & $\begin{array}{c}0.00 * * * \\
(0.00)\end{array}$ & $\begin{array}{c}0.00 \\
(0.00)\end{array}$ & $\begin{array}{c}0.00 * * * \\
(0.00)\end{array}$ \\
\hline Labor force participation rate & $\begin{array}{c}0.24 * * * \\
(0.04)\end{array}$ & $\begin{array}{c}-0.13^{* *} \\
(0.06)\end{array}$ & $\begin{array}{c}-0.04 * * * \\
(0.01)\end{array}$ & $\begin{array}{l}-0.02 \\
(0.05)\end{array}$ \\
\hline \% owner's education: high school & $\begin{array}{c}-0.09 * * \\
(0.04)\end{array}$ & $\begin{array}{c}0.02 \\
(0.03)\end{array}$ & $\begin{array}{c}0.02 \\
(0.01)\end{array}$ & $\begin{array}{c}0.02 \\
(0.02)\end{array}$ \\
\hline Some college & $\begin{array}{c}-0.08 * * \\
(0.04)\end{array}$ & $\begin{array}{c}0.01 \\
(0.04)\end{array}$ & $\begin{array}{l}-0.01 \\
(0.01)\end{array}$ & $\begin{array}{l}0.04 * \\
(0.03)\end{array}$ \\
\hline Trade school degree & $\begin{array}{c}0.04 \\
(0.04)\end{array}$ & $\begin{array}{c}0.01 \\
(0.04)\end{array}$ & $\begin{array}{l}-0.01 \\
(0.01)\end{array}$ & $\begin{array}{c}-0.07 * * \\
(0.04)\end{array}$ \\
\hline Associates degree & $\begin{array}{l}-0.09 \\
(0.06)\end{array}$ & $\begin{array}{c}0.04 \\
(0.06)\end{array}$ & $\begin{array}{c}0.00 \\
(0.02)\end{array}$ & $\begin{array}{c}0.02 \\
(0.05)\end{array}$ \\
\hline Bachelor's degree & $\begin{array}{c}-0.09 * * \\
(0.04)\end{array}$ & $\begin{array}{c}0.02 \\
(0.05)\end{array}$ & $\begin{array}{l}-0.00 \\
(0.02)\end{array}$ & $\begin{array}{l}-0.02 \\
(0.04)\end{array}$ \\
\hline Graduate school degree & $\begin{array}{c}0.02 \\
(0.05)\end{array}$ & $\begin{array}{c}0.06 \\
(0.05)\end{array}$ & $\begin{array}{l}-0.03 * \\
(0.02)\end{array}$ & $\begin{array}{c}0.02 \\
(0.04)\end{array}$ \\
\hline
\end{tabular}


Table 8. (cont'd)

\begin{tabular}{|c|c|c|c|c|}
\hline & $\begin{array}{c}\text { (1) } \\
\text { Income } \\
\text { Growth Rate }\end{array}$ & $\begin{array}{c}\text { (2) } \\
\text { Employment } \\
\text { Growth Rate }\end{array}$ & $\begin{array}{c}\text { (3) } \\
\text { Poverty Rate } \\
\text { Growth }\end{array}$ & $\begin{array}{c}\text { (4) } \\
\text { Population } \\
\text { Growth Rate }\end{array}$ \\
\hline Amenities & $\begin{array}{l}-0.00 \\
(0.00)\end{array}$ & $\begin{array}{l}-0.01 * * * \\
(0.00)\end{array}$ & $\begin{array}{l}0.00 * \\
(0.00)\end{array}$ & $\begin{array}{c}-0.01^{* *} \\
(0.00)\end{array}$ \\
\hline Rural-urban code 2 & -0.01 & $-0.01^{*}$ & 0.00 & $-0.02 * *$ \\
\hline Metro area, 0.25 to 1 million pop. & $(0.00)$ & $(0.01)$ & $(0.00)$ & $(0.01)$ \\
\hline Rural-urban code 3 & $-0.02 * * *$ & -0.01 & 0.00 & $-0.02 * *$ \\
\hline Metro area, $<250,000$ & $(0.01)$ & $(0.01)$ & $(0.00)$ & $(0.01)$ \\
\hline Rural-urban code 4 & $-0.03 * * *$ & $-0.03 * * *$ & $0.01 * * *$ & $-0.03 * * *$ \\
\hline Adjacent to metro, $\geq 20,000$ & $(0.01)$ & $(0.01)$ & $(0.00)$ & $(0.01)$ \\
\hline Rural-urban code 5 & $-0.02 * *$ & -0.01 & $0.01^{* *}$ & $-0.02 * *$ \\
\hline Not adjacent to metro, $\geq 20,000$ & $(0.01)$ & $(0.01)$ & $(0.00)$ & $(0.01)$ \\
\hline Rural-urban code 6 & $-0.03 * * *$ & $-0.02 * *$ & $0.01 * * *$ & $-0.02 * * *$ \\
\hline Adjacent to metro, 2,500-19,999 & $(0.01)$ & $(0.01)$ & $(0.00)$ & $(0.01)$ \\
\hline Rural-urban code 7 & $-0.02 * * *$ & $-0.02 * *$ & $0.01 * * *$ & $-0.03 * * *$ \\
\hline $\begin{array}{l}\text { Not adjacent to metro, 2,500- } \\
19,999\end{array}$ & $(0.01)$ & $(0.01)$ & $(0.00)$ & $(0.01)$ \\
\hline Rural-urban code 8 & $-0.03 * * *$ & $-0.02 * *$ & $0.01 * * *$ & $-0.02 * *$ \\
\hline Adjacent to a metro, $<2,500$ & $(0.01)$ & $(0.01)$ & $(0.00)$ & $(0.01)$ \\
\hline Rural-urban code 9 & $-0.03 * * *$ & $-0.02 * *$ & $0.01 * * *$ & $-0.02 * *$ \\
\hline Not adjacent to a metro, $<2,500$ & $(0.01)$ & $(0.01)$ & $(0.00)$ & $(0.01)$ \\
\hline Constant & $\begin{array}{l}-0.22 \\
(0.87)\end{array}$ & $\begin{array}{c}-1.58 * * \\
(0.66)\end{array}$ & $\begin{array}{c}0.10 \\
(0.21)\end{array}$ & $\begin{array}{c}-1.19 * * \\
(0.48)\end{array}$ \\
\hline Observations & $\sim 3,100^{5}$ & $\sim 3,100$ & $\sim 3,100$ & $\sim 3,100$ \\
\hline$R^{2}$ & 0.48 & 0.49 & 0.43 & 0.64 \\
\hline Industry employment & YES & YES & YES & YES \\
\hline Industry establishments & YES & YES & YES & YES \\
\hline State FE & YES & YES & YES & YES \\
\hline
\end{tabular}

The coefficient of primary interest is that on overall LOB employment share growth. This coefficient does not have a statistically significant impact on the measures of economic performance. Using overall LOB employment share in 2002 rather than the growth in that share also yields insignificant coefficients. The results of this regression are given in Table A7 in the

\footnotetext{
${ }^{5}$ Exact number of observations is suppressed by the Bureau of the Census to protect against improper disclosure.
} 
appendix. The coefficients on our convergence variables - per capita income employment, poverty rate, population - are consistent with catch-up growth; high initial per capita income is associated with lower per capita income growth and higher initial poverty is associated with lower poverty growth.

Average household size has a statistically significant impact on the income growth rate at the $99 \%$ level. The coefficient indicates that for every increase in average household size by 1 , the income growth rate will increase by 0.1 . As is consistent with the literature (Hoynes et al. 2006), the percent of households headed by a single female has a significant negative relationship with income, employment, and population growth, and a significant positive relationship with poverty growth. Having a higher proportion of the population with a level of education other than "less than a high school degree" (the omitted category) has a mostly statistically significant positive impact on per capita income, employment, and population growth, and a negative impact on poverty growth. The percent of business owners with various levels of education is mostly insignificant and, although the number of building permits issued is statistically significant, the coefficient is almost zero.

To take a more in depth look at the impact of LOB employment share, this paper next decomposes LOB employment share into LOB employment share in various industries. As it is likely that LOB employment share growth (2002-2007) is endogenously determined, we focus on the impact of LOB employment share in various industries in 2002. The results of this OLS regression are presented in Table A8 in the appendix.

Table A8 shows that the coefficients on variables other than LOB employment share remained mostly unchanged. Decomposing LOB employment share by industry reveals significant coefficients in various industries. As mentioned previously, however, given our data 
is on relatively small geographic regions, the spatial spillover effects are likely (Rey and Montouri 1999; Rupasingha et al. 2002; Rey and Janikas 2005). Such effects are common in regional growth literature and would at best leave the OLS regression inefficient, and at worst bias the results (LeSage and Fischer 2008). This paper uses the Spatial Durbin Model (SDM) to address this potential problem and focuses on those results. Table 9 presents the results of the SDM. As in Table 8, the SDM controls for industry employment, industry establishment counts, and state indicator variables, but the coefficients can be found in Table A9 in the appendix. For readability, some control variables with coefficients similar to the OLS model are also moved to Table A9 in the appendix, as have their spatial lags. 
Table 9. SDM Regressions of Economic Performance on 2002 Industry LOB Employment Share

\begin{tabular}{|c|c|c|c|c|}
\hline & $\begin{array}{c}\text { (1) } \\
\text { Income } \\
\text { Growth Rate }\end{array}$ & $\begin{array}{l}\text { (2) } \\
\text { Employment } \\
\text { Growth Rate }\end{array}$ & $\begin{array}{l}\text { (3) } \\
\text { Poverty } \\
\text { Growth }\end{array}$ & $\begin{array}{c}\text { (4) } \\
\text { Population } \\
\text { Growth Rate }\end{array}$ \\
\hline \multicolumn{5}{|l|}{ LOB share in NAICS sector: } \\
\hline 11: Agriculture, & $-0.04 * *$ & $0.04 *$ & 0.01 & 0.03 \\
\hline Forestry, Fishing, and Hunting & $(0.02)$ & $(0.02)$ & $(0.01)$ & $(0.02)$ \\
\hline 21: Mining, Quarrying, and & 0.01 & -0.03 & -0.00 & -0.05 \\
\hline Oil and Gas Extraction & $(0.04)$ & $(0.04)$ & $(0.01)$ & $(0.03)$ \\
\hline \multirow[t]{2}{*}{ 22: Utilities } & $0.21 *$ & $0.32 * *$ & $-0.08^{*}$ & $0.31 * *$ \\
\hline & $(0.11)$ & $(0.15)$ & $(0.04)$ & $(0.14)$ \\
\hline \multirow[t]{2}{*}{ 23: Construction } & $0.05 *$ & -0.01 & -0.00 & -0.02 \\
\hline & $(0.03)$ & $(0.03)$ & $(0.01)$ & $(0.02)$ \\
\hline \multirow[t]{2}{*}{ 31-33: Manufacturing } & -0.04 & -0.03 & -0.00 & 0.00 \\
\hline & $(0.04)$ & $(0.04)$ & $(0.02)$ & $(0.03)$ \\
\hline \multirow[t]{2}{*}{ 42: Wholesale Trade } & 0.06 & 0.03 & -0.01 & 0.02 \\
\hline & $(0.06)$ & $(0.06)$ & $(0.01)$ & $(0.05)$ \\
\hline \multirow[t]{2}{*}{ 44-45: Retail Trade } & 0.02 & 0.09 & 0.02 & 0.03 \\
\hline & $(0.06)$ & $(0.06)$ & $(0.03)$ & $(0.03)$ \\
\hline 48-49: Transportation and & 0.00 & 0.01 & 0.00 & 0.01 \\
\hline Warehousing & $(0.02)$ & $(0.02)$ & $(0.01)$ & $(0.02)$ \\
\hline \multirow[t]{2}{*}{ 51: Information } & -0.00 & $-0.14^{* *}$ & $-0.03^{*}$ & $-0.20 * * *$ \\
\hline & $(0.05)$ & $(0.06)$ & $(0.02)$ & $(0.07)$ \\
\hline \multirow[t]{2}{*}{ 52: Finance and Insurance } & -0.08 & 0.03 & -0.03 & 0.01 \\
\hline & $(0.07)$ & $(0.06)$ & $(0.04)$ & $(0.04)$ \\
\hline 53: Real Estate, Rental \& & $-0.06 * *$ & $-0.06 * *$ & $0.01 *$ & -0.02 \\
\hline Leasing & $(0.03)$ & $(0.03)$ & $(0.01)$ & $(0.03)$ \\
\hline 54: Professional, Scientific, and & $0.08 * * *$ & 0.05 & -0.01 & 0.00 \\
\hline Technical Services & $(0.03)$ & $(0.03)$ & $(0.01)$ & $(0.03)$ \\
\hline 55: Management of Companies & $0.11^{* * *}$ & 0.04 & -0.01 & $-0.07 * *$ \\
\hline and Enterprises & $(0.04)$ & $(0.05)$ & $(0.01)$ & $(0.03)$ \\
\hline 56: Administrative Support, & 0.03 & -0.02 & -0.02 & -0.03 \\
\hline Waste Management and & $(0.04)$ & $(0.05)$ & $(0.01)$ & $(0.02)$ \\
\hline \multicolumn{5}{|l|}{ Remediation Services } \\
\hline \multirow[t]{2}{*}{ 61: Educational Services } & -0.04 & -0.12 & -0.01 & -0.02 \\
\hline & $(0.03)$ & $(0.10)$ & $(0.01)$ & $(0.04)$ \\
\hline \multirow[t]{2}{*}{ 62: Health Care, Social Assist. } & 0.06 & 0.07 & 0.00 & 0.03 \\
\hline & $(0.05)$ & $(0.04)$ & $(0.02)$ & $(0.03)$ \\
\hline 71: Arts, Entertainment, and & 0.02 & 0.04 & 0.00 & 0.02 \\
\hline Recreation & $(0.02)$ & $(0.04)$ & $(0.01)$ & $(0.02)$ \\
\hline \multirow[t]{2}{*}{ 72: Accommodation, Food Serv. } & 0.01 & 0.01 & -0.00 & -0.01 \\
\hline & $(0.03)$ & $(0.02)$ & $(0.01)$ & $(0.02)$ \\
\hline \multirow[t]{2}{*}{ 81: Other Services } & $-0.07 * *$ & -0.04 & $0.02 *$ & $-0.04 * *$ \\
\hline & $(0.03)$ & $(0.03)$ & $(0.01)$ & $(0.02)$ \\
\hline
\end{tabular}


Table 9. (cont'd)

\begin{tabular}{|c|c|c|c|c|}
\hline & $\begin{array}{c}\text { (1) } \\
\text { Income } \\
\text { Growth Rate }\end{array}$ & $\begin{array}{l}\text { (2) } \\
\text { Employment } \\
\text { Growth Rate }\end{array}$ & $\begin{array}{c}\text { (3) } \\
\text { Poverty } \\
\text { Growth }\end{array}$ & $\begin{array}{c}\text { (4) } \\
\text { Population } \\
\text { Growth Rate }\end{array}$ \\
\hline \% with education: High school & $\begin{array}{c}0.29 * * * \\
(0.08)\end{array}$ & $\begin{array}{c}0.05 \\
(0.08)\end{array}$ & $\begin{array}{c}-0.05^{* *} \\
(0.02)\end{array}$ & $\begin{array}{l}-0.08 \\
(0.06)\end{array}$ \\
\hline Some college & $\begin{array}{c}0.34 * * * \\
(0.09)\end{array}$ & $\begin{array}{l}0.18^{* *} \\
(0.09)\end{array}$ & $\begin{array}{l}-0.04 \\
(0.03)\end{array}$ & $\begin{array}{c}0.15^{* *} \\
(0.08)\end{array}$ \\
\hline Associates degree & $\begin{array}{c}0.82 * * * \\
(0.17)\end{array}$ & $\begin{array}{c}0.20 \\
(0.16)\end{array}$ & $\begin{array}{c}-0.20 * * * \\
(0.05)\end{array}$ & $\begin{array}{l}-0.12 \\
(0.13)\end{array}$ \\
\hline Bachelor's degree & $\begin{array}{c}0.79 * * * \\
(0.12)\end{array}$ & $\begin{array}{c}0.44 * * * \\
(0.13)\end{array}$ & $\begin{array}{c}-0.10^{* * *} \\
(0.03)\end{array}$ & $\begin{array}{l}0.23^{*} \\
(0.13)\end{array}$ \\
\hline Graduate school degree & $\begin{array}{c}0.59 * * * \\
(0.15)\end{array}$ & $\begin{array}{c}0.18 \\
(0.20)\end{array}$ & $\begin{array}{c}0.12^{* *} \\
(0.04)\end{array}$ & $\begin{array}{c}0.06 \\
(0.15)\end{array}$ \\
\hline Amenities & $\begin{array}{l}-0.00 \\
(0.00)\end{array}$ & $\begin{array}{c}-0.01^{* * *} \\
(0.00)\end{array}$ & $\begin{array}{c}0.00 * * \\
(0.00)\end{array}$ & $\begin{array}{c}-0.01 * * \\
(0.00)\end{array}$ \\
\hline Rural-urban code 2 & 0.00 & 0.01 & $-0.01 * * *$ & 0.00 \\
\hline Metro area, 0.25 to 1 million pop. & $(0.01)$ & $(0.01)$ & $(0.00)$ & $(0.01)$ \\
\hline Rural-urban code 3 & -0.00 & 0.01 & $-0.00 *$ & -0.01 \\
\hline Metro area, $<250,000$ & $(0.01)$ & $(0.01)$ & $(0.00)$ & $(0.01)$ \\
\hline Rural-urban code 4 & $-0.02 * *$ & -0.01 & 0.00 & -0.01 \\
\hline Adjacent to metro, $\geq 20,000$ & $(0.01)$ & $(0.01)$ & $(0.00)$ & $(0.01)$ \\
\hline Rural-urban code 5 & $-0.02 *$ & -0.00 & 0.00 & -0.02 \\
\hline Not adjacent to metro, $\geq 20,000$ & $(0.01)$ & $(0.01)$ & $(0.00)$ & $(0.01)$ \\
\hline Rural-urban code 6 & $-0.01 * *$ & -0.00 & 0.00 & -0.01 \\
\hline Adjacent to metro, 2,500-19,999 & $(0.01)$ & $(0.01)$ & $(0.00)$ & $(0.01)$ \\
\hline Rural-urban code 7 & -0.01 & -0.01 & 0.00 & $-0.02 * *$ \\
\hline Not adjacent to metro, 2,500-19,999 & $(0.01)$ & $(0.01)$ & $(0.00)$ & $(0.01)$ \\
\hline Rural-urban code 8 & $-0.02 * *$ & -0.00 & 0.00 & -0.01 \\
\hline Adjacent to a metro, $<2,500$ & $(0.01)$ & $(0.01)$ & $(0.00)$ & $(0.01)$ \\
\hline Rural-urban code 9 & $-0.02 * *$ & -0.01 & $0.01 *$ & -0.01 \\
\hline Not adjacent to a metro, $<2,500$ & $(0.01)$ & $(0.01)$ & $(0.00)$ & $(0.01)$ \\
\hline
\end{tabular}


Table 9 (cont'd)

\begin{tabular}{|c|c|c|c|c|}
\hline Spatial Lags & $\begin{array}{c}\text { (1) } \\
\text { Income } \\
\text { Growth Rate }\end{array}$ & $\begin{array}{l}\text { (2) } \\
\text { Employment } \\
\text { Growth Rate }\end{array}$ & $\begin{array}{l}\text { (3) } \\
\text { Poverty } \\
\text { Growth }\end{array}$ & $\begin{array}{c}\text { (4) } \\
\text { Population } \\
\text { Growth Rate }\end{array}$ \\
\hline \multicolumn{5}{|l|}{ LOB share in NAICS sector: } \\
\hline 11: Agriculture, Forestry, & $-0.02 * * *$ & -0.01 & $0.01 * *$ & 0.00 \\
\hline Fishing and Hunting & $(0.01)$ & $(0.01)$ & $(0.00)$ & $(0.01)$ \\
\hline 21: Mining, Quarrying, and Oil & -0.01 & 0.01 & $-0.02 * * *$ & $-0.03 *$ \\
\hline and Gas Extraction & $(0.02)$ & $(0.02)$ & $(0.01)$ & $(0.01)$ \\
\hline \multirow[t]{2}{*}{ 22: Utilities } & $0.14 * *$ & $0.37 * * *$ & $-0.05 * *$ & $0.29 * * *$ \\
\hline & $(0.06)$ & $(0.08)$ & $(0.02)$ & $(0.06)$ \\
\hline \multirow[t]{2}{*}{ 23: Construction } & -0.00 & 0.01 & $-0.01 * * *$ & -0.01 \\
\hline & $(0.01)$ & $(0.01)$ & $(0.00)$ & $(0.01)$ \\
\hline \multirow[t]{2}{*}{ 31-33: Manufacturing } & 0.00 & -0.02 & -0.00 & $-0.02 * *$ \\
\hline & $(0.01)$ & $(0.01)$ & $(0.00)$ & $(0.01)$ \\
\hline \multirow[t]{2}{*}{ 42: Wholesale Trade } & 0.01 & $0.02 *$ & -0.00 & 0.00 \\
\hline & $(0.01)$ & $(0.01)$ & $(0.00)$ & $(0.01)$ \\
\hline \multirow[t]{2}{*}{ 44-45: Retail Trade } & $-0.05 * * *$ & -0.01 & 0.00 & -0.01 \\
\hline & $(0.02)$ & $(0.02)$ & $(0.01)$ & $(0.01)$ \\
\hline 48-49: Transportation and & 0.00 & -0.00 & $0.00 *$ & 0.00 \\
\hline Warehousing & $(0.00)$ & $(0.01)$ & $(0.00)$ & $(0.01)$ \\
\hline \multirow[t]{2}{*}{ 51: Information } & -0.01 & $-0.04 * *$ & -0.01 & $-0.03 * *$ \\
\hline & $(0.02)$ & $(0.02)$ & $(0.01)$ & $(0.01)$ \\
\hline \multirow[t]{2}{*}{ 52: Finance and Insurance } & 0.00 & $0.04 * *$ & -0.01 & $0.04 * *$ \\
\hline & $(0.02)$ & $(0.02)$ & $(0.01)$ & $(0.02)$ \\
\hline 53: Real Estate, Rental \& & -0.00 & 0.01 & -0.00 & 0.00 \\
\hline Leasing & $(0.01)$ & $(0.01)$ & $(0.00)$ & $(0.01)$ \\
\hline 54: Professional, Scientific, and & 0.01 & 0.01 & -0.00 & 0.01 \\
\hline Technical Services & $(0.01)$ & $(0.01)$ & $(0.00)$ & $(0.01)$ \\
\hline 55: Management of Companies & $0.02 *$ & -0.01 & -0.00 & -0.01 \\
\hline and Enterprises & $(0.01)$ & $(0.02)$ & $(0.01)$ & $(0.01)$ \\
\hline 56: Administrative Support, & -0.00 & $-0.02 *$ & -0.00 & $-0.02 *$ \\
\hline Waste Management and & $(0.01)$ & $(0.01)$ & $(0.00)$ & $(0.01)$ \\
\hline \multicolumn{5}{|l|}{ Remediation Services } \\
\hline \multirow[t]{2}{*}{ 61: Educational Services } & -0.02 & $-0.03 *$ & 0.00 & -0.02 \\
\hline & $(0.01)$ & $(0.02)$ & $(0.00)$ & $(0.01)$ \\
\hline \multirow{2}{*}{ 62: Health Care, Social Assist. } & 0.01 & 0.01 & $0.01 * * *$ & 0.01 \\
\hline & $(0.02)$ & $(0.01)$ & $(0.01)$ & $(0.01)$ \\
\hline 71: Arts, Entertainment, and & $0.01 *$ & 0.01 & 0.00 & 0.01 \\
\hline Recreation & $(0.01)$ & $(0.01)$ & $(0.00)$ & $(0.01)$ \\
\hline \multirow[t]{2}{*}{ 72: Accommodation, Food Serv. } & 0.00 & 0.00 & 0.00 & -0.00 \\
\hline & $(0.00)$ & $(0.00)$ & $(0.00)$ & $(0.00)$ \\
\hline \multirow[t]{2}{*}{ 81: Other Services } & $-0.02 * *$ & $-0.03 * * *$ & $0.01 * * *$ & $-0.02 * * *$ \\
\hline & $(0.01)$ & $(0.01)$ & $(0.00)$ & $(0.01)$ \\
\hline
\end{tabular}


Table 9 (cont'd)

\begin{tabular}{|c|c|c|c|c|}
\hline Spatial Lags & $\begin{array}{c}\text { (1) } \\
\text { Income } \\
\text { Growth Rate }\end{array}$ & $\begin{array}{l}\text { (2) } \\
\text { Employment } \\
\text { Growth Rate }\end{array}$ & $\begin{array}{c}\text { (3) } \\
\text { Poverty } \\
\text { Growth }\end{array}$ & $\begin{array}{c}\text { (4) } \\
\text { Population } \\
\text { Growth Rate }\end{array}$ \\
\hline \% with education: High school & $\begin{array}{l}-0.01 \\
(0.01)\end{array}$ & $\begin{array}{l}-0.00 \\
(0.01)\end{array}$ & $\begin{array}{c}0.00 \\
(0.00)\end{array}$ & $\begin{array}{c}0.01 \\
(0.01)\end{array}$ \\
\hline Some college & $\begin{array}{l}-0.00 \\
(0.01)\end{array}$ & $\begin{array}{c}0.01 \\
(0.01)\end{array}$ & $\begin{array}{l}-0.00 \\
(0.00)\end{array}$ & $\begin{array}{c}0.03 * * * \\
(0.01)\end{array}$ \\
\hline Associates degree & $\begin{array}{l}-0.03 \\
(0.02)\end{array}$ & $\begin{array}{l}-0.01 \\
(0.02)\end{array}$ & $\begin{array}{c}0.00 \\
(0.01)\end{array}$ & $\begin{array}{l}-0.03^{*} \\
(0.02)\end{array}$ \\
\hline Bachelor's degree & $\begin{array}{c}0.01 \\
(0.02)\end{array}$ & $\begin{array}{c}0.00 \\
(0.02)\end{array}$ & $\begin{array}{l}-0.00 \\
(0.01)\end{array}$ & $\begin{array}{l}-0.00 \\
(0.02)\end{array}$ \\
\hline graduate school degree & $\begin{array}{l}-0.02 \\
(0.02)\end{array}$ & $\begin{array}{c}0.00 \\
(0.03)\end{array}$ & $\begin{array}{l}0.01 * \\
(0.01)\end{array}$ & $\begin{array}{c}0.03 \\
(0.02)\end{array}$ \\
\hline Amenities & $\begin{array}{l}-0.00 \\
(0.00)\end{array}$ & $\begin{array}{c}-0.00 * * \\
(0.00)\end{array}$ & $\begin{array}{c}0.00 \\
(0.00)\end{array}$ & $\begin{array}{c}-0.00^{* *} \\
(0.00)\end{array}$ \\
\hline Rural-urban code 2 & $0.00 *$ & 0.00 & $-0.00 *$ & -0.00 \\
\hline Metro area, 0.25 to 1 million pop. & $(0.00)$ & $(0.00)$ & $(0.00)$ & $(0.00)$ \\
\hline Rural-urban code 3 & 0.00 & 0.00 & $-0.00 * *$ & -0.00 \\
\hline Metro area, $<250,000$ & $(0.00)$ & $(0.00)$ & $(0.00)$ & $(0.00)$ \\
\hline Rural-urban code 4 & $0.00 *$ & 0.00 & -0.00 & 0.00 \\
\hline Adjacent to metro, $\geq 20,000$ & $(0.00)$ & $(0.00)$ & $(0.00)$ & $(0.00)$ \\
\hline Rural-urban code 5 & $-0.00 * *$ & 0.00 & $0.00 *$ & 0.00 \\
\hline Not adjacent to metro, $\geq 20,000$ & $(0.00)$ & $(0.00)$ & $(0.00)$ & $(0.00)$ \\
\hline Rural-urban code 6 & 0.00 & $0.00 *$ & -0.00 & 0.00 \\
\hline Adjacent to metro, 2,500-19,999 & $(0.00)$ & $(0.00)$ & $(0.00)$ & $(0.00)$ \\
\hline Rural-urban code 7 & $0.00 * * *$ & $0.00 *$ & $-0.00 * *$ & 0.00 \\
\hline Not adjacent to metro, 2,500-19,999 & $(0.00)$ & $(0.00)$ & $(0.00)$ & $(0.00)$ \\
\hline Rural-urban code 8 & -0.00 & 0.00 & -0.00 & 0.00 \\
\hline Adjacent to a metro, $<2,500$ & $(0.00)$ & $(0.00)$ & $(0.00)$ & $(0.00)$ \\
\hline Rural-urban code 9 & 0.00 & $0.00 * * *$ & $-0.00 * * *$ & 0.00 \\
\hline Not adjacent to a metro, $<2,500$ & $(0.00)$ & $(0.00)$ & $(0.00)$ & $(0.00)$ \\
\hline Constant & $\begin{array}{c}0.29 \\
(0.80)\end{array}$ & $\begin{array}{l}-0.99 \\
(0.64)\end{array}$ & $\begin{array}{c}0.03 \\
(0.20)\end{array}$ & $\begin{array}{l}-0.61 \\
(0.47)\end{array}$ \\
\hline Observations & $\sim 3,100$ & $\sim 3,100$ & $\sim 3,100$ & $\sim 3,100$ \\
\hline Industry employment & YES & YES & YES & YES \\
\hline Industry establishments & YES & YES & YES & YES \\
\hline State & YES & YES & YES & YES \\
\hline
\end{tabular}


Table 9. (cont'd)

\begin{tabular}{|c|c|c|c|c|}
\hline & $\begin{array}{c}\text { (1) } \\
\text { Income } \\
\text { Growth Rate }\end{array}$ & $\begin{array}{l}\quad(2) \\
\text { Employment } \\
\text { Growth Rate }\end{array}$ & $\begin{array}{l}\text { (3) } \\
\text { Poverty } \\
\text { Growth }\end{array}$ & $\begin{array}{c}\text { (4) } \\
\text { Population } \\
\text { Growth Rate }\end{array}$ \\
\hline$\rho$ & $\begin{array}{c}-0.02 * * * \\
(0.00)\end{array}$ & $\begin{array}{l}-0.01 \\
(0.00)\end{array}$ & $\begin{array}{c}-0.02 * * * \\
(0.00)\end{array}$ & $\begin{array}{c}-0.01 * * * \\
(0.01)\end{array}$ \\
\hline Wald test of $\rho=0\left(C h i^{2}(1)\right)$ & $\begin{array}{c}29.78 * * * \\
(0.00)\end{array}$ & $\begin{array}{c}2.38 \\
(0.12)\end{array}$ & $\begin{array}{c}24.15^{* * *} \\
(0.00)\end{array}$ & $\begin{array}{l}7.98 * * * \\
(0.01)\end{array}$ \\
\hline $\begin{array}{l}\text { Wald test for coefficients on lags } \\
\text { of } X=0\left(C h i^{2}(260)\right)\end{array}$ & $\begin{array}{c}470.01 * * * \\
(0.00)\end{array}$ & $\begin{array}{c}428.00 * * * \\
(0.00)\end{array}$ & $\begin{array}{c}400.65^{* * * *} \\
(0.00)\end{array}$ & $\begin{array}{l}497.02 * * * \\
(0.00)\end{array}$ \\
\hline
\end{tabular}

The Spatial Durbin Model reveals statistically significant changes in the coefficients on LOB employment share decomposed by industry when compared to the OLS results. Further, the Wald test for significance of $\rho$ reveals that we can reject $\rho=0$ in all of the regressions except employment growth. Hence, we can reject with 99\% confidence that neighboring counties’ income, poverty, and population growth do not impact a county's own income, poverty, and population growth. Further, the Wald test on the coefficients on the spatial lags of the dependent variables is significant in all four regressions at the $99 \%$ confidence level. Thus, it appears that a model failing to account for neighboring counties’ control variables risks omitted variable bias. With these tests in mind, this paper will focus on the SDM results presented in Table A6.

More employment under LOB in the agriculture, forestry, fishing, and hunting sector has a significant and positive relationship with employment growth, but a significant and negative relationship with income growth. Share of LOB employment in the construction industry has a significant and positive relationship with the income growth rate. A one percentage point increase in LOB employment share in the utilities industry is associated with a statistically 
significant .0021, .0032, and .0031 increase in the income, employment, and population growth rate, respectively. Share of LOB employment in the utilities sector has a similar significant negative relationship with poverty growth. Share of LOB employment share in the professional, scientific, and technical services and the management of companies and enterprises industries both have a significant and positive relationship with income growth, though management of companies and enterprises has a significant and negative relationship with population growth.

The USDA rural-urban continuum code indicator variables 4, 5, 6, 8, and 9 all have a significant negative impact on per capita income growth. The omitted category is 1 , which is the most metro (or least rural) categorization. Although this relationship is not significant for code 7, (nonmetro county with urban population of 2,500-19,999, not adjacent to a metro area), code 7 does have a significant and negative relationship with population growth.

The coefficients on the spatial lags of the SDM are also included in Table A6. The coefficients on neighboring counties’ per capita income, employment, and poverty rate growth are consistent with past research into regional convergence (Rey and Janikas 2005, Rey and Montouri 1999). Neighboring counties’ LOB employment share in the construction industry has a significant and negative relationship with poverty rate growth. Neighboring counties' LOB employment share in retail has a significant and negative relationship with income growth.

\section{Conclusions and Suggestions for Future Research}

Much research has examined the effect of immigration on measures of economic performance (see Massey 1993, Zhou 2004) and the relative survival of different ethnic groups in self-employment (e.g., Borjas 1990, Fairlie and Robb 2008). Despite this research, few studies 
examine the impact of employment by various ethnic groups on measures of economic success. Indeed, less is known about the contributions of minority-owned businesses in general and Latino-owned business (LOB) in particular to economic performance at the local level in the U.S. Despite numerous calls for minority-owned business promotion as a local development strategy to create income and employment, to alleviate poverty, and to discourage population loss, this paper is one of the first examinations specifically into these potential relationships. Furthermore, by breaking down the impact of LOB by industry, this paper examines these impacts on local economies with more precision than past work, which has examined the impact on the low and high-skill labor markets. Although we can reject the first hypothesis (H1), that LOB employment share has a positive impact on the local economic performance measures, when this paper divides the LOB employment share by industry, we find both positive and negative impacts on economic performance measures.

As mentioned previously, Latinos tend to concentrate in the services (Puryear et al. 2008, Robles and Cordero-Guzmán 2007), construction, wholesale trade, and retail trade sectors (U.S. Census Bureau 2010). As explained above, high barrier industries include professional services and finance or insurance, and typically require an advanced degree or large amounts of startup capital. Low barrier industries, conversely, do not require an advanced degree or a large amount of start-up capital and include some food services and construction. Martinez et al. (2011) show that LOB are often associated with these low-barrier industries because they lack financial capital to enter high-barrier industries. Indeed, past research suggests that business owners with large amounts of personal capital to invest on business startup will be able to open more fastergrowing businesses in a high-barrier industry, while others experience relatively slow growth (and less survival) in the low-barrier businesses (Bates, Lofstrom, and Servnon 2010). Given this 
past research, one would expect a different effect of LOB employment share in high-barrier and low-barrier industries on local economic performance.

This paper’s results indeed support H2 (LOB employment share in low-barrier industries has a negative impact on the local economic performance measures), and H3 (LOB employment share in high-barrier industries has a positive impact on the local economic performance measures), with exceptions. LOB employment share in (1) agriculture, forestry, fishing, and hunting, (2) real estate and rental and leasing, and (3) other services industries all have a negative effect on per capita income growth, while LOB employment share in the (1) utilities, (2) construction, (3) professional, scientific, and technical services, and (4) management of companies and enterprises industries have a positive effect on per capita income. Thus the relationship holds with the exception of construction, which has a statistically significant and positive effect on per capita income. Further, these regressions control for building permits issued and hence it is unlikely that this relationship can be attributed to more construction activity in an area. It may be that LOB tend to work high-skill jobs within the construction industry relative to other ethnicities.

This paper's results on the impact of LOB employment share on population growth rates also contribute to another stream of literature on immigrant and native flows. The LOB employment share in information, management of companies and enterprises, and other services industries all have a negative impact on population growth. This paper does not specify that the LOB must be immigrant-LOB, but over 1 in 3 Latinos in the U.S. are immigrants (Zong and Batalova 2015). Thus the results presented here partially contradict H4 (Immigrant inflows do not imply selective out-migration by natives). Though this paper similarly found no overall effect, breaking down the overall effect by industry share, this paper shows that there is a 
statistically significant effect of LOB employment share that varies by industry. Further, most of the LOB employment share spatial lags’ impact on population growth are also negative. Thus we can reject our fifth hypothesis (H5), that large concentrations of immigrants in surrounding areas reduce native out-mobility, and this paper does not support theoretical arguments related to the distance dependence of mobility.

Finally, it is again important to emphasize that Latino workers and LOB in the United States are not a monolithic group of low-wage migrants (Zarrugh 2007). Although this research broke down the impact of LOB by industry, future research may thus want to control for the LOB's country of origin and education levels, given availability of such data. Researchers may also want to control for potential interactions between employment under other ethnic groups and employment under LOB. Furthermore, just as disaggregating LOB employment across industries revealed significant impacts of LOB employment share in this paper, disaggregating LOB employment share further (to higher-digit NAICS codes) may reveal more impacts hidden by the aggregation to 2-digit NAICS coded industries. For example, this paper indicates that more details on the construction industry may be of interest to further investigate the supposed low and high-barrier industrial divide among LOB. That is, while the results indicate that LOB employment in the construction sector is positively related with per capita income growth, it is possible that the story may be more nuanced if the sector is more finely divided into higher-order and lower-order construction services. Such details may be useful to economic development practitioners. Finally, future research may want to interact rurality with LOB share variables; although this paper controlled for rurality, it may be that the impact of LOB in each industry varies nonlinearly with rurality. 


\section{APPENDIX}

Table A6. OLS Regressions of Economic Performance on LOB Employment Share Growth

\begin{tabular}{|c|c|c|c|c|}
\hline NAICS Sector & $\begin{array}{c}\text { (1) } \\
\text { Income } \\
\text { Growth Rate }\end{array}$ & $\begin{array}{l}\text { (2) } \\
\text { Employment } \\
\text { Growth Rate }\end{array}$ & $\begin{array}{c}\text { (3) } \\
\text { Poverty Rate } \\
\text { Growth }\end{array}$ & $\begin{array}{c}\text { (4) } \\
\text { Population } \\
\text { Growth Rate }\end{array}$ \\
\hline Employment under 11: Ag., & 0.00 & 0.00 & 0.00 & 0.00 \\
\hline Forestry, Fishing and Hunting & $(0.00)$ & $(0.00)$ & $(0.00)$ & $(0.00)$ \\
\hline 21: Mining, Quarrying, and Oil & 0.00 & 0.00 & -0.00 & 0.00 \\
\hline and Gas Extraction & $(0.00)$ & $(0.00)$ & $(0.00)$ & $(0.00)$ \\
\hline \multirow[t]{2}{*}{ 22: Utilities } & $0.00 *$ & $0.00 * * *$ & -0.00 & 0.00 \\
\hline & $(0.00)$ & $(0.00)$ & $(0.00)$ & $(0.00)$ \\
\hline \multirow[t]{2}{*}{ 23: Construction } & 0.00 & $-0.00 * * *$ & -0.00 & $-0.00 * * *$ \\
\hline & $(0.00)$ & $(0.00)$ & $(0.00)$ & $(0.00)$ \\
\hline \multirow[t]{2}{*}{ 31-33: Manufacturing } & $-0.00 * * *$ & 0.00 & $0.00 * *$ & $0.00 *$ \\
\hline & $(0.00)$ & $(0.00)$ & $(0.00)$ & $(0.00)$ \\
\hline \multirow[t]{2}{*}{ 42: Wholesale Trade } & -0.00 & 0.00 & $-0.00 *$ & 0.00 \\
\hline & $(0.00)$ & $(0.00)$ & $(0.00)$ & $(0.00)$ \\
\hline \multirow[t]{2}{*}{ 44-45: Retail Trade } & -0.00 & -0.00 & 0.00 & $-0.00 *$ \\
\hline & $(0.00)$ & $(0.00)$ & $(0.00)$ & $(0.00)$ \\
\hline 48-49: Transportation and & -0.00 & 0.00 & 0.00 & 0.00 \\
\hline Warehousing & $(0.00)$ & $(0.00)$ & $(0.00)$ & $(0.00)$ \\
\hline \multirow[t]{2}{*}{ 51: Information } & 0.00 & $-0.00 * *$ & $0.00 * *$ & $-0.00 * *$ \\
\hline & $(0.00)$ & $(0.00)$ & $(0.00)$ & $(0.00)$ \\
\hline \multirow[t]{2}{*}{ 52: Finance and Insurance } & -0.00 & -0.00 & 0.00 & 0.00 \\
\hline & $(0.00)$ & $(0.00)$ & $(0.00)$ & $(0.00)$ \\
\hline 53: Real Estate, Rental \& & $0.00 *$ & $0.00 *$ & -0.00 & 0.00 \\
\hline Leasing & $(0.00)$ & $(0.00)$ & $(0.00)$ & $(0.00)$ \\
\hline 54: Professional, Scientific, and & $0.00 * *$ & $0.00 * * *$ & -0.00 & 0.00 \\
\hline Technical Services & $(0.00)$ & $(0.00)$ & $(0.00)$ & $(0.00)$ \\
\hline 55: Management of Companies & 0.00 & -0.00 & 0.00 & 0.00 \\
\hline and Enterprises & $(0.00)$ & $(0.00)$ & $(0.00)$ & $(0.00)$ \\
\hline 56: Administrative Support, & 0.00 & $-0.00 * * *$ & 0.00 & $-0.00 * * *$ \\
\hline Waste Management and & $(0.00)$ & $(0.00)$ & $(0.00)$ & $(0.00)$ \\
\hline \multicolumn{5}{|l|}{ Remediation Services } \\
\hline \multirow[t]{2}{*}{ 61: Educational Services } & $-0.00 *$ & 0.00 & -0.00 & 0.00 \\
\hline & $(0.00)$ & $(0.00)$ & $(0.00)$ & $(0.00)$ \\
\hline \multirow[t]{2}{*}{ 62: Health Care, Social Assist. } & 0.00 & 0.00 & 0.00 & $0.00 * *$ \\
\hline & $(0.00)$ & $(0.00)$ & $(0.00)$ & $(0.00)$ \\
\hline 71: Arts, Entertainment, and & -0.00 & $-0.00 *$ & -0.00 & -0.00 \\
\hline Recreation & $(0.00)$ & $(0.00)$ & $(0.00)$ & $(0.00)$ \\
\hline
\end{tabular}


Table A6. (cont'd)

\begin{tabular}{|c|c|c|c|c|}
\hline NAICS Sector & $\begin{array}{c}\text { (1) } \\
\text { Income } \\
\text { Growth Rate }\end{array}$ & $\begin{array}{c}\text { (2) } \\
\text { Employment } \\
\text { Growth Rate }\end{array}$ & $\begin{array}{c}\text { (3) } \\
\text { Poverty Rate } \\
\text { Growth }\end{array}$ & $\begin{array}{c}\text { (4) } \\
\text { Population } \\
\text { Growth Rate }\end{array}$ \\
\hline 72: Accommodation, Food Serv. & $\begin{array}{c}0.00 \\
(0.00)\end{array}$ & $\begin{array}{l}-0.00 \\
(0.00)\end{array}$ & $\begin{array}{l}-0.00 \\
(0.00)\end{array}$ & $\begin{array}{l}-0.00 \\
(0.00)\end{array}$ \\
\hline 81: Other Services & $\begin{array}{c}0.00 \\
(0.00)\end{array}$ & $\begin{array}{c}0.00 * * \\
(0.00)\end{array}$ & $\begin{array}{c}0.00 \\
(0.00)\end{array}$ & $\begin{array}{l}0.00 * * \\
(0.00)\end{array}$ \\
\hline $\begin{array}{l}\% \text { of establishments under } 11 \text { : } \\
\text { Ag., Forestry, Fishing, Hunting }\end{array}$ & $\begin{array}{l}-0.73 \\
(0.86)\end{array}$ & $\begin{array}{l}1.42 * * \\
(0.65)\end{array}$ & $\begin{array}{c}0.22 \\
(0.21)\end{array}$ & $\begin{array}{l}1.08 * * \\
(0.45)\end{array}$ \\
\hline $\begin{array}{l}\text { 21: Mining, Quarrying, and Oil } \\
\text { and Gas Extraction }\end{array}$ & $\begin{array}{l}-0.21 \\
(0.87)\end{array}$ & $\begin{array}{c}1.75 * * * \\
(0.65)\end{array}$ & $\begin{array}{c}0.20 \\
(0.21)\end{array}$ & $\begin{array}{c}1.45^{* * * *} \\
(0.44)\end{array}$ \\
\hline 22: Utilities & $\begin{array}{l}-0.49 \\
(1.37)\end{array}$ & $\begin{array}{l}-0.00 \\
(1.17)\end{array}$ & $\begin{array}{c}0.49 \\
(0.45)\end{array}$ & $\begin{array}{c}0.22 \\
(0.81)\end{array}$ \\
\hline 23: Construction & $\begin{array}{l}-0.80 \\
(0.86)\end{array}$ & $\begin{array}{c}2.05^{* * *} \\
(0.65)\end{array}$ & $\begin{array}{c}0.27 \\
(0.21)\end{array}$ & $\begin{array}{c}1.94 * * * \\
(0.45)\end{array}$ \\
\hline 31-33: Manufacturing & $\begin{array}{l}-1.42 \\
(0.87)\end{array}$ & $\begin{array}{l}1.32 * * \\
(0.66)\end{array}$ & $\begin{array}{c}0.32 \\
(0.21)\end{array}$ & $\begin{array}{c}1.43 * * * \\
(0.45)\end{array}$ \\
\hline 42: Wholesale Trade & $\begin{array}{l}-0.43 \\
(0.90)\end{array}$ & $\begin{array}{l}1.71^{* *} \\
(0.69)\end{array}$ & $\begin{array}{c}0.29 \\
(0.22)\end{array}$ & $\begin{array}{c}1.37 * * * \\
(0.47)\end{array}$ \\
\hline 44-45: Retail Trade & $\begin{array}{l}-0.69 \\
(0.84)\end{array}$ & $\begin{array}{l}1.51^{* *} \\
(0.67)\end{array}$ & $\begin{array}{c}0.25 \\
(0.21)\end{array}$ & $\begin{array}{c}1.36 * * * \\
(0.47)\end{array}$ \\
\hline $\begin{array}{l}\text { 48-49: Transportation and } \\
\text { Warehousing }\end{array}$ & $\begin{array}{l}-0.72 \\
(0.90)\end{array}$ & $\begin{array}{l}1.89 * * * \\
(0.68)\end{array}$ & $\begin{array}{c}0.25 \\
(0.21)\end{array}$ & $\begin{array}{c}1.66 * * * \\
(0.45)\end{array}$ \\
\hline 51: Information & $\begin{array}{c}0.44 \\
(1.19)\end{array}$ & $\begin{array}{l}1.83^{*} \\
(1.01)\end{array}$ & $\begin{array}{l}-0.00 \\
(0.27)\end{array}$ & $\begin{array}{c}1.04 \\
(0.73)\end{array}$ \\
\hline 52: Finance and Insurance & $\begin{array}{l}-0.85 \\
(0.88)\end{array}$ & $\begin{array}{l}1.55^{* *} \\
(0.62)\end{array}$ & $\begin{array}{c}0.22 \\
(0.23)\end{array}$ & $\begin{array}{c}1.40 * * * \\
(0.49)\end{array}$ \\
\hline 53: Real Estate, Rental \& & -0.36 & $2.25 * * *$ & 0.26 & $2.10 * * *$ \\
\hline Leasing & $(0.85)$ & $(0.65)$ & $(0.21)$ & $(0.45)$ \\
\hline $\begin{array}{l}\text { 54: Professional, Scientific, and } \\
\text { Technical Services }\end{array}$ & $\begin{array}{l}-0.38 \\
(0.87)\end{array}$ & $\begin{array}{l}1.52 * * \\
(0.63)\end{array}$ & $\begin{array}{c}0.17 \\
(0.21)\end{array}$ & $\begin{array}{l}1.61^{* * *} \\
(0.44)\end{array}$ \\
\hline $\begin{array}{l}\text { 55: Management of Companies } \\
\text { and Enterprises }\end{array}$ & $\begin{array}{c}1.09 \\
(1.52)\end{array}$ & $\begin{array}{l}2.53^{*} \\
(1.35)\end{array}$ & $\begin{array}{l}-0.16 \\
(0.43)\end{array}$ & $\begin{array}{l}-0.05 \\
(1.07)\end{array}$ \\
\hline $\begin{array}{l}\text { 56: Administrative Support, } \\
\text { Waste Management and } \\
\text { Remediation Services }\end{array}$ & $\begin{array}{l}-0.43 \\
(0.87)\end{array}$ & $\begin{array}{c}2.24 * * * \\
(0.68)\end{array}$ & $\begin{array}{c}0.28 \\
(0.21)\end{array}$ & $\begin{array}{c}1.99 * * * \\
(0.46)\end{array}$ \\
\hline 61: Educational Services & $\begin{array}{l}-0.63 \\
(0.97)\end{array}$ & $\begin{array}{c}0.91 \\
(0.90)\end{array}$ & $\begin{array}{c}0.29 \\
(0.26)\end{array}$ & $\begin{array}{c}0.95 \\
(0.64)\end{array}$ \\
\hline 62: Health Care, Social Assist. & $\begin{array}{l}-1.01 \\
(0.88)\end{array}$ & $\begin{array}{l}1.60 * * \\
(0.65)\end{array}$ & $\begin{array}{c}0.29 \\
(0.20)\end{array}$ & $\begin{array}{c}1.52 * * * \\
(0.44)\end{array}$ \\
\hline $\begin{array}{l}\text { 71: Arts, Entertainment, and } \\
\text { Recreation }\end{array}$ & $\begin{array}{l}-0.67 \\
(0.84)\end{array}$ & $\begin{array}{c}1.80 * * * \\
(0.66)\end{array}$ & $\begin{array}{c}0.21 \\
(0.22)\end{array}$ & $\begin{array}{c}1.54 * * * \\
(0.52)\end{array}$ \\
\hline
\end{tabular}


Table A6. (cont'd)

\begin{tabular}{|c|c|c|c|c|}
\hline NAICS Sector and States & $\begin{array}{c}\text { (1) } \\
\text { Income } \\
\text { Growth Rate }\end{array}$ & $\begin{array}{l}\text { (2) } \\
\text { Employment } \\
\text { Growth Rate }\end{array}$ & $\begin{array}{l}\text { (3) } \\
\text { Poverty Rate } \\
\text { Growth }\end{array}$ & $\begin{array}{c}\text { (4) } \\
\text { Population } \\
\text { Growth Rate }\end{array}$ \\
\hline 72: Accommodation, Food Serv. & $\begin{array}{c}-0.25 \\
(0.94)\end{array}$ & $\begin{array}{l}1.76^{* *} \\
(0.71)\end{array}$ & $\begin{array}{c}0.24 \\
(0.22)\end{array}$ & $\begin{array}{c}1.10^{* *} \\
(0.47)\end{array}$ \\
\hline 81: Other Services & $\begin{array}{l}-0.73 \\
(0.87)\end{array}$ & $\begin{array}{l}1.38 * * \\
(0.64)\end{array}$ & $\begin{array}{c}0.23 \\
(0.21)\end{array}$ & $\begin{array}{c}1.31 * * * \\
(0.46)\end{array}$ \\
\hline Arizona & $\begin{array}{l}-0.04^{*} \\
(0.02)\end{array}$ & $\begin{array}{l}0.08^{*} \\
(0.04)\end{array}$ & $\begin{array}{c}0.01 \\
(0.01)\end{array}$ & $\begin{array}{c}0.06 \\
(0.04)\end{array}$ \\
\hline Arkansas & $\begin{array}{c}-0.04 * * * \\
(0.01)\end{array}$ & $\begin{array}{c}-0.03^{* *} \\
(0.01)\end{array}$ & $\begin{array}{c}0.02^{* * * *} \\
(0.00)\end{array}$ & $\begin{array}{l}-0.01 \\
(0.01)\end{array}$ \\
\hline California & $\begin{array}{c}0.00 \\
(0.02)\end{array}$ & $\begin{array}{l}0.04 * \\
(0.02)\end{array}$ & $\begin{array}{l}-0.00 \\
(0.01)\end{array}$ & $\begin{array}{c}0.03 \\
(0.02)\end{array}$ \\
\hline Colorado & $\begin{array}{l}-0.03 \\
(0.02)\end{array}$ & $\begin{array}{l}-0.03 \\
(0.02)\end{array}$ & $\begin{array}{c}0.01 * * \\
(0.01)\end{array}$ & $\begin{array}{c}-0.03^{* *} \\
(0.02)\end{array}$ \\
\hline Connecticut & $\begin{array}{c}0.09 * * * \\
(0.02)\end{array}$ & $\begin{array}{c}0.03 \\
(0.02)\end{array}$ & $\begin{array}{c}-0.01 * * \\
(0.01)\end{array}$ & $\begin{array}{l}-0.02 \\
(0.02)\end{array}$ \\
\hline Delaware & $\begin{array}{l}-0.00 \\
(0.04)\end{array}$ & $\begin{array}{l}0.07 * * \\
(0.03)\end{array}$ & $\begin{array}{c}0.00 \\
(0.01)\end{array}$ & $\begin{array}{c}0.13^{* * *} \\
(0.02)\end{array}$ \\
\hline District of Columbia & $\begin{array}{c}0.11 \\
(0.11)\end{array}$ & $\begin{array}{l}-0.04 \\
(0.10)\end{array}$ & $\begin{array}{l}-0.04^{*} \\
(0.02)\end{array}$ & $\begin{array}{l}-0.10 \\
(0.09)\end{array}$ \\
\hline Florida & $\begin{array}{c}-0.04^{* * *} * \\
(0.02)\end{array}$ & $\begin{array}{c}0.08 * * * \\
(0.02)\end{array}$ & $\begin{array}{c}0.01^{* *} \\
(0.01)\end{array}$ & $\begin{array}{c}0.10 * * * \\
(0.02)\end{array}$ \\
\hline Geogia & $\begin{array}{c}-0.06 * * * \\
(0.01)\end{array}$ & $\begin{array}{c}0.01 \\
(0.01)\end{array}$ & $\begin{array}{c}0.01 * * * \\
(0.00)\end{array}$ & $\begin{array}{c}0.05^{* * * *} \\
(0.01)\end{array}$ \\
\hline Idaho & $\begin{array}{c}-0.09 * * * \\
(0.02)\end{array}$ & $\begin{array}{c}0.00 \\
(0.02)\end{array}$ & $\begin{array}{c}0.02 * * \\
(0.01)\end{array}$ & $\begin{array}{c}0.01 \\
(0.02)\end{array}$ \\
\hline Illinois & $\begin{array}{l}-0.02 * \\
(0.01)\end{array}$ & $\begin{array}{l}-0.02 \\
(0.02)\end{array}$ & $\begin{array}{c}0.02 * * * \\
(0.00)\end{array}$ & $\begin{array}{l}-0.02 * \\
(0.01)\end{array}$ \\
\hline Indiana & $\begin{array}{c}-0.06 * * * \\
(0.01)\end{array}$ & $\begin{array}{c}-0.07 * * * \\
(0.02)\end{array}$ & $\begin{array}{c}0.02 * * * \\
(0.00)\end{array}$ & $\begin{array}{c}-0.05 * * * \\
(0.01)\end{array}$ \\
\hline Iowa & $\begin{array}{l}-0.01 \\
(0.02)\end{array}$ & $\begin{array}{l}-0.02 \\
(0.02)\end{array}$ & $\begin{array}{c}0.01^{* *} \\
(0.01)\end{array}$ & $\begin{array}{c}-0.04 * * * \\
(0.01)\end{array}$ \\
\hline Kansas & $\begin{array}{c}-0.06 * * * \\
(0.02)\end{array}$ & $\begin{array}{l}-0.03^{*} \\
(0.02)\end{array}$ & $\begin{array}{l}0.01 * * \\
(0.01)\end{array}$ & $\begin{array}{c}-0.06 * * * \\
(0.01)\end{array}$ \\
\hline Kentucky & $\begin{array}{l}-0.02 \\
(0.01)\end{array}$ & $\begin{array}{c}-0.03^{* *} \\
(0.01)\end{array}$ & $\begin{array}{c}0.02^{* * *} \\
(0.00)\end{array}$ & $\begin{array}{l}-0.01 \\
(0.01)\end{array}$ \\
\hline Louisiana & $\begin{array}{c}0.06^{* * *} \\
(0.02)\end{array}$ & $\begin{array}{c}0.02 \\
(0.02)\end{array}$ & $\begin{array}{c}-0.01^{* *} \\
(0.01)\end{array}$ & $\begin{array}{l}-0.01 \\
(0.02)\end{array}$ \\
\hline Maine & $\begin{array}{l}-0.01 \\
(0.02)\end{array}$ & $\begin{array}{c}0.01 \\
(0.02)\end{array}$ & $\begin{array}{c}0.01 \\
(0.01)\end{array}$ & $\begin{array}{c}0.01 \\
(0.02)\end{array}$ \\
\hline Maryland & $\begin{array}{c}0.08 * * * \\
(0.02)\end{array}$ & $\begin{array}{c}0.04 * * \\
(0.02)\end{array}$ & $\begin{array}{c}-0.02 * * * \\
(0.01)\end{array}$ & $\begin{array}{c}0.01 \\
(0.02)\end{array}$ \\
\hline
\end{tabular}


Table A6. (cont'd)

\begin{tabular}{|c|c|c|c|c|}
\hline State Variables & $\begin{array}{c}\text { (1) } \\
\text { Income } \\
\text { Growth Rate }\end{array}$ & $\begin{array}{l}\text { (2) } \\
\text { Employment } \\
\text { Growth Rate }\end{array}$ & $\begin{array}{c}\text { (3) } \\
\text { Poverty Rate } \\
\text { Growth }\end{array}$ & $\begin{array}{c}\text { (4) } \\
\text { Population } \\
\text { Growth Rate }\end{array}$ \\
\hline Massachusetts & $\begin{array}{l}0.06^{*} \\
(0.03)\end{array}$ & $\begin{array}{c}-0.01 \\
(0.02)\end{array}$ & $\begin{array}{c}-0.01 * * \\
(0.01)\end{array}$ & $\begin{array}{c}-0.04^{* *} \\
(0.02)\end{array}$ \\
\hline Michigan & $\begin{array}{c}-0.09 * * * \\
(0.01)\end{array}$ & $\begin{array}{c}-0.11 * * * \\
(0.02)\end{array}$ & $\begin{array}{c}0.03 * * * \\
(0.01)\end{array}$ & $\begin{array}{c}-0.08 * * * \\
(0.01)\end{array}$ \\
\hline Minnesota & $\begin{array}{l}-0.01 \\
(0.02)\end{array}$ & $\begin{array}{c}0.00 \\
(0.02)\end{array}$ & $\begin{array}{c}0.01 * * * \\
(0.01)\end{array}$ & $\begin{array}{l}-0.02 * \\
(0.01)\end{array}$ \\
\hline Mississippi & $\begin{array}{c}-0.03^{* *} \\
(0.01)\end{array}$ & $\begin{array}{c}-0.03^{*} \\
(0.02)\end{array}$ & $\begin{array}{c}0.01 * * * \\
(0.00)\end{array}$ & $\begin{array}{c}-0.01 \\
(0.01)\end{array}$ \\
\hline Missouri & $\begin{array}{c}-0.04 * * * \\
(0.01)\end{array}$ & $\begin{array}{c}0.00 \\
(0.01)\end{array}$ & $\begin{array}{c}0.01^{* *} \\
(0.00)\end{array}$ & $\begin{array}{c}0.00 \\
(0.01)\end{array}$ \\
\hline Montana & $\begin{array}{l}-0.03^{*} \\
(0.02)\end{array}$ & $\begin{array}{c}0.02 \\
(0.02)\end{array}$ & $\begin{array}{c}0.01 \\
(0.01)\end{array}$ & $\begin{array}{c}0.02 \\
(0.02)\end{array}$ \\
\hline Nebraska & $\begin{array}{c}-0.04^{* *} \\
(0.02)\end{array}$ & $\begin{array}{l}-0.01 \\
(0.02)\end{array}$ & $\begin{array}{c}0.01 * * \\
(0.01)\end{array}$ & $\begin{array}{c}-0.03^{* *} \\
(0.01)\end{array}$ \\
\hline Nevada & $\begin{array}{l}-0.03 \\
(0.04)\end{array}$ & $\begin{array}{c}0.05 \\
(0.03)\end{array}$ & $\begin{array}{l}0.02 * \\
(0.01)\end{array}$ & $\begin{array}{c}0.06 \\
(0.04)\end{array}$ \\
\hline New Hampshire & $\begin{array}{c}0.00 \\
(0.02)\end{array}$ & $\begin{array}{l}-0.00 \\
(0.02)\end{array}$ & $\begin{array}{l}-0.00 \\
(0.01)\end{array}$ & $\begin{array}{c}-0.04^{* *} \\
(0.02)\end{array}$ \\
\hline New Jersey & $\begin{array}{c}0.05^{* * *} \\
(0.02)\end{array}$ & $\begin{array}{l}-0.04^{*} \\
(0.02)\end{array}$ & $\begin{array}{l}-0.00 \\
(0.01)\end{array}$ & $\begin{array}{c}-0.07 * * * \\
(0.02)\end{array}$ \\
\hline New Mexico & $\begin{array}{l}-0.03 \\
(0.03)\end{array}$ & $\begin{array}{c}0.03 \\
(0.03)\end{array}$ & $\begin{array}{l}-0.00 \\
(0.01)\end{array}$ & $\begin{array}{c}0.02 \\
(0.02)\end{array}$ \\
\hline New York & $\begin{array}{l}-0.01 \\
(0.02)\end{array}$ & $\begin{array}{l}-0.00 \\
(0.02)\end{array}$ & $\begin{array}{c}0.00 \\
(0.01)\end{array}$ & $\begin{array}{l}-0.02 \\
(0.01)\end{array}$ \\
\hline North Carolina & $\begin{array}{c}-0.03^{* *} \\
(0.01)\end{array}$ & $\begin{array}{l}-0.01 \\
(0.01)\end{array}$ & $\begin{array}{c}0.02^{* * *} \\
(0.00)\end{array}$ & $\begin{array}{c}0.04^{* * *} \\
(0.01)\end{array}$ \\
\hline North Dakota & $\begin{array}{c}0.06 * * * \\
(0.02)\end{array}$ & $\begin{array}{c}0.02 \\
(0.02)\end{array}$ & $\begin{array}{c}0.00 \\
(0.01)\end{array}$ & $\begin{array}{c}-0.04^{* *} \\
(0.02)\end{array}$ \\
\hline Ohio & $\begin{array}{c}-0.05 * * * \\
(0.01)\end{array}$ & $\begin{array}{c}-0.06 * * * \\
(0.02)\end{array}$ & $\begin{array}{c}0.02 * * * \\
(0.01)\end{array}$ & $\begin{array}{c}-0.05 * * * \\
(0.01)\end{array}$ \\
\hline Oklahoma & $\begin{array}{c}-0.04^{* *} \\
(0.02)\end{array}$ & $\begin{array}{c}0.01 \\
(0.02)\end{array}$ & $\begin{array}{c}0.01 \\
(0.01)\end{array}$ & $\begin{array}{c}0.01 \\
(0.01)\end{array}$ \\
\hline Oregon & $\begin{array}{c}-0.05 * * * \\
(0.02)\end{array}$ & $\begin{array}{c}0.01 \\
(0.02)\end{array}$ & $\begin{array}{c}0.02 * * * \\
(0.01)\end{array}$ & $\begin{array}{c}0.02 \\
(0.02)\end{array}$ \\
\hline Pennsylvania & $\begin{array}{l}-0.02 \\
(0.02)\end{array}$ & $\begin{array}{c}0.00 \\
(0.02)\end{array}$ & $\begin{array}{l}-0.00 \\
(0.01)\end{array}$ & $\begin{array}{l}-0.01 \\
(0.01)\end{array}$ \\
\hline Rhode Island & $\begin{array}{c}0.05^{* * *} \\
(0.02)\end{array}$ & $\begin{array}{l}-0.04 * \\
(0.03)\end{array}$ & $\begin{array}{c}-0.02 * * * \\
(0.01)\end{array}$ & $\begin{array}{c}-0.10 * * * \\
(0.02)\end{array}$ \\
\hline South Carolina & $\begin{array}{c}-0.04 * * * \\
(0.01)\end{array}$ & $\begin{array}{l}-0.01 \\
(0.02)\end{array}$ & $\begin{array}{c}0.02^{* * *} \\
(0.01)\end{array}$ & $\begin{array}{c}0.04^{* * *} \\
(0.01)\end{array}$ \\
\hline
\end{tabular}


Table A6. (cont'd)

\begin{tabular}{lcccc}
\hline \multirow{2}{*}{ State Variables } & $\begin{array}{c}(1) \\
\text { Income } \\
\text { Growth Rate }\end{array}$ & $\begin{array}{c}(2) \\
\text { Employment } \\
\text { Growth Rate }\end{array}$ & $\begin{array}{c}(3) \\
\text { Poverty Rate } \\
\text { Growth }\end{array}$ & $\begin{array}{c}(4) \\
\text { Population } \\
\text { Growth Rate }\end{array}$ \\
\hline \multirow{3}{*}{ South Dakota } & & & & \\
Tennessee & 0.01 & 0.01 & 0.01 & -0.02 \\
Texas & $(0.02)$ & $(0.02)$ & $(0.01)$ & $(0.02)$ \\
Utah & $-0.03^{* *}$ & $-0.04^{* * *}$ & $0.02^{* * *}$ & 0.00 \\
& $(0.01)$ & $(0.01)$ & $(0.00)$ & $(0.01)$ \\
Vermont & $-0.03^{*}$ & $0.03^{* *}$ & 0.01 & 0.01 \\
Virginia & $(0.01)$ & $(0.01)$ & $(0.00)$ & $(0.01)$ \\
& $-0.07^{* * *}$ & -0.01 & -0.01 & 0.01 \\
Washington & $(0.03)$ & $(0.03)$ & $(0.01)$ & $(0.02)$ \\
West Virginia & 0.00 & -0.02 & -0.00 & $-0.05^{* * *}$ \\
& $(0.02)$ & $(0.02)$ & $(0.01)$ & $(0.02)$ \\
Wisconsin & $0.03^{* * *}$ & 0.01 & $-0.01 *$ & 0.01 \\
Wyoming & $(0.01)$ & $(0.02)$ & $(0.00)$ & $(0.01)$ \\
& $-0.04^{* *}$ & $0.04^{*}$ & $0.02^{* * *}$ & $0.06^{* * *}$ \\
& $(0.02)$ & $(0.02)$ & $(0.01)$ & $(0.02)$ \\
& $-0.04^{* *}$ & 0.02 & 0.00 & 0.01 \\
& $(0.02)$ & $(0.02)$ & $(0.01)$ & $(0.01)$ \\
& $-0.03^{* *}$ & -0.01 & $0.02^{* * *}$ & -0.02 \\
& $(0.02)$ & $(0.02)$ & $(0.01)$ & $(0.01)$ \\
& $0.04^{*}$ & $0.08^{* * *}$ & $-0.02^{* *}$ & $0.06^{* *}$ \\
& $(0.02)$ & $(0.03)$ & $(0.01)$ & $(0.02)$ \\
\hline
\end{tabular}

Robust standard errors in parentheses

*** $\mathrm{p}<0.01,{ }^{* *} \mathrm{p}<0.05,{ }^{*} \mathrm{p}<0.1$ 
Table A7. OLS Regression of Economic Performance on 2002 LOB Employment Share

\begin{tabular}{|c|c|c|c|c|}
\hline County Variables & $\begin{array}{c}\text { (1) } \\
\text { Income } \\
\text { Growth Rate }\end{array}$ & $\begin{array}{l}\text { (2) } \\
\text { Employment } \\
\text { Growth Rate }\end{array}$ & $\begin{array}{c}\text { (3) } \\
\text { Poverty Rate } \\
\text { Growth }\end{array}$ & $\begin{array}{c}\text { (4) } \\
\text { Population } \\
\text { Growth Rate }\end{array}$ \\
\hline LOB employment share & $\begin{array}{c}0.01 \\
(0.07)\end{array}$ & $\begin{array}{c}0.05 \\
(0.06)\end{array}$ & $\begin{array}{l}-0.01 \\
(0.04)\end{array}$ & $\begin{array}{l}-0.04 \\
(0.04)\end{array}$ \\
\hline Per capita income & $\begin{array}{c}-0.00 * * * \\
(0.00)\end{array}$ & $\begin{array}{c}-0.00 * * * \\
(0.00)\end{array}$ & $\begin{array}{c}-0.00 * * * \\
(0.00)\end{array}$ & $\begin{array}{l}-0.00^{*} \\
(0.00)\end{array}$ \\
\hline Employment & $\begin{array}{l}-0.00 \\
(0.00)\end{array}$ & $\begin{array}{c}-0.00 * * * \\
(0.00)\end{array}$ & $\begin{array}{c}0.00 * * \\
(0.00)\end{array}$ & $\begin{array}{l}-0.00 \\
(0.00)\end{array}$ \\
\hline Poverty rate & $\begin{array}{c}0.30 * * * \\
(0.08)\end{array}$ & $\begin{array}{l}-0.05 \\
(0.09)\end{array}$ & $\begin{array}{c}-0.48 * * * \\
(0.03)\end{array}$ & $\begin{array}{l}-0.13^{*} \\
(0.07)\end{array}$ \\
\hline Population & $\begin{array}{c}0.00 \\
(0.00)\end{array}$ & $\begin{array}{l}-0.00 \\
(0.00)\end{array}$ & $\begin{array}{c}-0.00 * * * \\
(0.00)\end{array}$ & $\begin{array}{c}-0.00 * * \\
(0.00)\end{array}$ \\
\hline Population squared & $\begin{array}{l}-0.00 \\
(0.00)\end{array}$ & $\begin{array}{l}-0.00 \\
(0.00)\end{array}$ & $\begin{array}{c}0.00 * * * \\
(0.00)\end{array}$ & $\begin{array}{l}-0.00 \\
(0.00)\end{array}$ \\
\hline Population density & $\begin{array}{l}0.00 * * \\
(0.00)\end{array}$ & $\begin{array}{l}-0.00 \\
(0.00)\end{array}$ & $\begin{array}{l}-0.00 \\
(0.00)\end{array}$ & $\begin{array}{l}-0.00^{*} \\
(0.00)\end{array}$ \\
\hline Average household size & $\begin{array}{c}0.10^{* * *} \\
(0.02)\end{array}$ & $\begin{array}{c}0.12 * * * \\
(0.02)\end{array}$ & $\begin{array}{l}-0.00 \\
(0.01)\end{array}$ & $\begin{array}{c}0.06 * * * \\
(0.02)\end{array}$ \\
\hline $\begin{array}{l}\% \text { of households headed by } \\
\text { single female }\end{array}$ & $\begin{array}{c}-0.59 * * * \\
(0.08)\end{array}$ & $\begin{array}{c}-0.39 * * * \\
(0.09)\end{array}$ & $\begin{array}{c}0.29 * * * \\
(0.03)\end{array}$ & $\begin{array}{c}-0.48 * * * \\
(0.07)\end{array}$ \\
\hline Median age & $\begin{array}{c}0.03 * * * \\
(0.01)\end{array}$ & $\begin{array}{l}-0.01^{*} \\
(0.01)\end{array}$ & $\begin{array}{c}-0.01^{* * *} \\
(0.00)\end{array}$ & $\begin{array}{l}-0.01 \\
(0.01)\end{array}$ \\
\hline Median age squared & $\begin{array}{c}-0.00 * * * \\
(0.00)\end{array}$ & $\begin{array}{l}0.00 * \\
(0.00)\end{array}$ & $\begin{array}{c}0.00 * * * \\
(0.00)\end{array}$ & $\begin{array}{c}0.00 \\
(0.00)\end{array}$ \\
\hline Female population & $\begin{array}{l}-0.00 \\
(0.00)\end{array}$ & $\begin{array}{l}0.0 *^{*} \\
(0.00)\end{array}$ & $\begin{array}{c}0.00 * * * \\
(0.00)\end{array}$ & $\begin{array}{c}0.00 * * \\
(0.00)\end{array}$ \\
\hline Female population squared & $\begin{array}{c}0.00 \\
(0.00)\end{array}$ & $\begin{array}{c}0.00 \\
(0.00)\end{array}$ & $\begin{array}{c}-0.00 * * * \\
(0.00)\end{array}$ & $\begin{array}{c}0.00 \\
(0.00)\end{array}$ \\
\hline Asian population & $\begin{array}{l}-0.00 \\
(0.00)\end{array}$ & $\begin{array}{c}0.00 \\
(0.00)\end{array}$ & $\begin{array}{c}0.00 \\
(0.00)\end{array}$ & $\begin{array}{c}0.00 \\
(0.00)\end{array}$ \\
\hline Asian population squared & $\begin{array}{c}0.00 \\
(0.00)\end{array}$ & $\begin{array}{c}0.00 \\
(0.00)\end{array}$ & $\begin{array}{c}0.00 \\
(0.00)\end{array}$ & $\begin{array}{c}0.00 \\
(0.00)\end{array}$ \\
\hline Black population & $\begin{array}{l}-0.00 \\
(0.00)\end{array}$ & $\begin{array}{l}-0.00 * \\
(0.00)\end{array}$ & $\begin{array}{c}-0.00 * * * \\
(0.00)\end{array}$ & $\begin{array}{c}-0.00 * * * \\
(0.00)\end{array}$ \\
\hline Black population squared & $\begin{array}{l}-0.00 \\
(0.00)\end{array}$ & $\begin{array}{c}0.00 \\
(0.00)\end{array}$ & $\begin{array}{c}0.00 * * * \\
(0.00)\end{array}$ & $\begin{array}{c}0.00 * * \\
(0.00)\end{array}$ \\
\hline Hispanic population & $\begin{array}{c}-0.00 * * \\
(0.00)\end{array}$ & $\begin{array}{c}0.00 \\
(0.00)\end{array}$ & $\begin{array}{l}0.00 * \\
(0.00)\end{array}$ & $\begin{array}{l}0.00^{*} \\
(0.00)\end{array}$ \\
\hline Hispanic population squared & $\begin{array}{l}-0.00 \\
(0.00)\end{array}$ & $\begin{array}{l}-0.00 \\
(0.00)\end{array}$ & $\begin{array}{c}0.00 \\
(0.00)\end{array}$ & $\begin{array}{c}0.00 \\
(0.00)\end{array}$ \\
\hline
\end{tabular}


Table A7. (cont'd)

\begin{tabular}{|c|c|c|c|c|}
\hline County Variables & $\begin{array}{c}(1) \\
\text { Income } \\
\text { Growth Rate }\end{array}$ & $\begin{array}{l}\quad(2) \\
\text { Employment } \\
\text { Growth Rate }\end{array}$ & $\begin{array}{l}\text { (3) } \\
\text { Poverty Rate } \\
\text { Growth }\end{array}$ & $\begin{array}{c}\text { (4) } \\
\text { Population } \\
\text { Growth Rate }\end{array}$ \\
\hline$\%$ with education: high school & $\begin{array}{c}0.32^{* * *} \\
(0.07)\end{array}$ & $\begin{array}{l}0.12 * \\
(0.07)\end{array}$ & $\begin{array}{c}-0.09 * * * \\
(0.02)\end{array}$ & $\begin{array}{c}0.03 \\
(0.05)\end{array}$ \\
\hline Some college & $\begin{array}{c}0.37^{* * * *} \\
(0.08)\end{array}$ & $\begin{array}{c}0.24^{* * *} \\
(0.09)\end{array}$ & $\begin{array}{c}-0.09 * * * \\
(0.03)\end{array}$ & $\begin{array}{l}0.19 * * \\
(0.07)\end{array}$ \\
\hline Associates degree & $\begin{array}{c}0.75^{* * * *} \\
(0.16)\end{array}$ & $\begin{array}{c}0.18 \\
(0.15)\end{array}$ & $\begin{array}{c}-0.21 * * * \\
(0.05)\end{array}$ & $\begin{array}{l}-0.19 \\
(0.12)\end{array}$ \\
\hline Bachelor's degree & $\begin{array}{c}0.78^{* * * *} \\
(0.12)\end{array}$ & $\begin{array}{c}0.59^{* * * *} \\
(0.13)\end{array}$ & $\begin{array}{c}-0.11^{* * * *} \\
(0.03)\end{array}$ & $\begin{array}{c}0.35 * * \\
(0.14)\end{array}$ \\
\hline Graduate school degree & $\begin{array}{c}0.69 * * * \\
(0.15)\end{array}$ & $\begin{array}{c}0.20 \\
(0.19)\end{array}$ & $\begin{array}{l}0.08^{*} \\
(0.05)\end{array}$ & $\begin{array}{c}0.15 \\
(0.15)\end{array}$ \\
\hline \% owner's education: high school & $\begin{array}{c}-0.09 * * \\
(0.04)\end{array}$ & $\begin{array}{c}0.02 \\
(0.03)\end{array}$ & $\begin{array}{c}0.02 \\
(0.01)\end{array}$ & $\begin{array}{c}0.02 \\
(0.02)\end{array}$ \\
\hline Some college & $\begin{array}{c}-0.08^{* * *} \\
(0.04)\end{array}$ & $\begin{array}{c}0.01 \\
(0.04)\end{array}$ & $\begin{array}{l}-0.01 \\
(0.01)\end{array}$ & $\begin{array}{l}0.04^{*} \\
(0.03)\end{array}$ \\
\hline Trade school degree & $\begin{array}{c}0.04 \\
(0.04)\end{array}$ & $\begin{array}{c}0.01 \\
(0.04)\end{array}$ & $\begin{array}{l}-0.01 \\
(0.01)\end{array}$ & $\begin{array}{c}-0.07^{*} \\
(0.04)\end{array}$ \\
\hline Associates degree & $\begin{array}{l}-0.09 \\
(0.06)\end{array}$ & $\begin{array}{c}0.04 \\
(0.06)\end{array}$ & $\begin{array}{c}0.00 \\
(0.02)\end{array}$ & $\begin{array}{c}0.02 \\
(0.05)\end{array}$ \\
\hline Bachelor's degree & $\begin{array}{c}-0.09 * * \\
(0.04)\end{array}$ & $\begin{array}{c}0.02 \\
(0.05)\end{array}$ & $\begin{array}{l}-0.00 \\
(0.02)\end{array}$ & $\begin{array}{l}-0.02 \\
(0.04)\end{array}$ \\
\hline Graduate school degree & $\begin{array}{c}0.02 \\
(0.05)\end{array}$ & $\begin{array}{c}0.06 \\
(0.05)\end{array}$ & $\begin{array}{c}-0.03^{*} \\
(0.02)\end{array}$ & $\begin{array}{c}0.02 \\
(0.04)\end{array}$ \\
\hline Taxes per capita & $\begin{array}{l}-0.00^{*} \\
(0.00)\end{array}$ & $\begin{array}{l}-0.00 \\
(0.00)\end{array}$ & $\begin{array}{c}0.00 \\
(0.00)\end{array}$ & $\begin{array}{l}-0.00 \\
(0.00)\end{array}$ \\
\hline Education spending & $\begin{array}{l}-0.00 \\
(0.00)\end{array}$ & $\begin{array}{c}0.00 \\
(0.00)\end{array}$ & $\begin{array}{c}0.00 \\
(0.00)\end{array}$ & $\begin{array}{l}-0.00 \\
(0.00)\end{array}$ \\
\hline Highway spending & $\begin{array}{c}0.00 \\
(0.00)\end{array}$ & $\begin{array}{l}-0.00 \\
(0.00)\end{array}$ & $\begin{array}{l}-0.00 \\
(0.00)\end{array}$ & $\begin{array}{c}0.00 \\
(0.00)\end{array}$ \\
\hline Labor force participation rate & $\begin{array}{c}0.24^{* * * *} \\
(0.04)\end{array}$ & $\begin{array}{c}-0.14^{* * *} \\
(0.06)\end{array}$ & $\begin{array}{c}-0.04 * * * \\
(0.01)\end{array}$ & $\begin{array}{l}-0.02 \\
(0.05)\end{array}$ \\
\hline Build permits & $\begin{array}{c}-0.00 * * \\
(0.00)\end{array}$ & $\begin{array}{c}0.00^{* * * *} \\
(0.00)\end{array}$ & $\begin{array}{c}0.00 \\
(0.00)\end{array}$ & $\begin{array}{c}0.00^{* * *} \\
(0.00)\end{array}$ \\
\hline
\end{tabular}


Table A7. (cont'd)

(1) (2) (3) (4)

County Variables
Income Employment Poverty Rate Population Growth Rate Growth Rate Growth Growth Rate

Amenities

Rural-urban code 2

Metro area, 0.25 to 1 million pop.

Rural-urban code 3

Metro area, $<250,000$

Rural-urban code 4

Adjacent to metro, $\geq 20,000$

Rural-urban code 5

Not adjacent to metro, $\geq 20,000$

Rural-urban code 6

Adjacent to metro, 2,500-19,999

Rural-urban code 7

Not adjacent to metro, 2,500-19,999

Rural-urban code 8

Adjacent to a metro, $<2,500$

Rural-urban code 9

Not adjacent to a metro, $<2,500$

$\begin{array}{cccc}-0.00 & -0.01^{* * *} & 0.00^{*} & -0.01^{* *} \\ (0.00) & (0.00) & (0.00) & (0.00) \\ -0.01 & -0.01^{*} & 0.00 & -0.02^{* *} \\ (0.00) & (0.01) & (0.00) & (0.01) \\ -0.02^{* * *} & -0.01 & 0.00 & -0.02^{* *} \\ (0.01) & (0.01) & (0.00) & (0.01) \\ -0.03^{* * *} & -0.03^{* * *} & 0.01^{* * *} & -0.03^{* * *} \\ (0.01) & (0.01) & (0.00) & (0.01) \\ -0.02^{* *} & -0.01 & 0.01^{* *} & -0.02^{* *} \\ (0.01) & (0.01) & (0.00) & (0.01) \\ -0.03^{* * *} & -0.02^{* *} & 0.01^{* * *} & -0.02^{* * *} \\ (0.01) & (0.01) & (0.00) & (0.01) \\ -0.02^{* * *} & -0.02^{* *} & 0.01^{* * *} & -0.03^{* * *} \\ (0.01) & (0.01) & (0.00) & (0.01) \\ -0.03^{* * *} & -0.02^{* *} & 0.01^{* * *} & -0.02^{* *} \\ (0.01) & (0.01) & (0.00) & (0.01) \\ -0.03^{* * *} & -0.02^{* *} & 0.01^{* * *} & -0.02^{* *} \\ (0.01) & (0.01) & (0.00) & (0.01)\end{array}$


Table A7. (cont'd)

\begin{tabular}{|c|c|c|c|c|}
\hline NAICS Sector & $\begin{array}{c}(1) \\
\text { Income } \\
\text { Growth Rate }\end{array}$ & $\begin{array}{l}\quad(2) \\
\text { Employment } \\
\text { Growth Rate }\end{array}$ & $\begin{array}{l}\text { (3) } \\
\text { Poverty Rate } \\
\text { Growth }\end{array}$ & $\begin{array}{c}\text { (4) } \\
\text { Population } \\
\text { Growth Rate }\end{array}$ \\
\hline Employment under 11: & 0.00 & 0.00 & 0.00 & 0.00 \\
\hline Ag., Forestry, Fishing, Hunting & $(0.00)$ & $(0.00)$ & $(0.00)$ & $(0.00)$ \\
\hline 21: Mining, Quarrying, and & 0.00 & 0.00 & -0.00 & 0.00 \\
\hline Oil and Gas Extraction & $(0.00)$ & $(0.00)$ & $(0.00)$ & $(0.00)$ \\
\hline 22: Utilities & $\begin{array}{l}0.00^{*} \\
(0.00)\end{array}$ & $\begin{array}{c}0.00 * * * \\
(0.00)\end{array}$ & $\begin{array}{l}-0.00 \\
(0.00)\end{array}$ & $\begin{array}{c}0.00 \\
(0.00)\end{array}$ \\
\hline 23: Construction & $\begin{array}{c}0.00 \\
(0.00)\end{array}$ & $\begin{array}{c}-0.00^{* * * *} \\
(0.00)\end{array}$ & $\begin{array}{l}-0.00 \\
(0.00)\end{array}$ & $\begin{array}{c}-0.00^{* * * *} \\
(0.00)\end{array}$ \\
\hline 31-33: Manufacturing & $\begin{array}{c}-0.00^{* * *} \\
(0.00)\end{array}$ & $\begin{array}{c}0.00 \\
(0.00)\end{array}$ & $\begin{array}{c}0.00 * * \\
(0.00)\end{array}$ & $\begin{array}{l}0.00^{*} \\
(0.00)\end{array}$ \\
\hline 42: Wholesale Trade & $\begin{array}{l}-0.00 \\
(0.00)\end{array}$ & $\begin{array}{c}0.00 \\
(0.00)\end{array}$ & $\begin{array}{l}-0.00^{*} \\
(0.00)\end{array}$ & $\begin{array}{c}0.00 \\
(0.00)\end{array}$ \\
\hline 44-45: Retail Trade & $\begin{array}{l}-0.00^{*} \\
(0.00)\end{array}$ & $\begin{array}{l}-0.00 \\
(0.00)\end{array}$ & $\begin{array}{c}0.00 \\
(0.00)\end{array}$ & $\begin{array}{l}-0.00^{*} \\
(0.00)\end{array}$ \\
\hline $\begin{array}{l}\text { 48-49: Transportation and } \\
\text { Warehousing }\end{array}$ & $\begin{array}{l}-0.00 \\
(0.00)\end{array}$ & $\begin{array}{c}0.00 \\
(0.00)\end{array}$ & $\begin{array}{c}0.00 \\
(0.00)\end{array}$ & $\begin{array}{c}0.00 \\
(0.00)\end{array}$ \\
\hline 51: Information & $\begin{array}{c}0.00 \\
(0.00)\end{array}$ & $\begin{array}{c}-0.00^{* *} \\
(0.00)\end{array}$ & $\begin{array}{c}0.00^{* *} \\
(0.00)\end{array}$ & $\begin{array}{c}-0.00^{* *} \\
(0.00)\end{array}$ \\
\hline 52: Finance and Insurance & $\begin{array}{l}-0.00 \\
(0.00)\end{array}$ & $\begin{array}{l}-0.00 \\
(0.00)\end{array}$ & $\begin{array}{c}0.00 \\
(0.00)\end{array}$ & $\begin{array}{c}0.00 \\
(0.00)\end{array}$ \\
\hline $\begin{array}{l}\text { 53: Real Estate, Rental \& } \\
\text { Leasing }\end{array}$ & $\begin{array}{l}0.00^{*} \\
(0.00)\end{array}$ & $\begin{array}{l}0.00^{*} \\
(0.00)\end{array}$ & $\begin{array}{l}-0.00 \\
(0.00)\end{array}$ & $\begin{array}{c}0.00 \\
(0.00)\end{array}$ \\
\hline $\begin{array}{l}\text { 54: Professional, Scientific, and } \\
\text { Technical Services }\end{array}$ & $\begin{array}{c}0.00 * * \\
(0.00)\end{array}$ & $\begin{array}{c}0.00^{* * *} \\
(0.00)\end{array}$ & $\begin{array}{r}-0.00 \\
(0.00)\end{array}$ & $\begin{array}{c}0.00 \\
(0.00)\end{array}$ \\
\hline $\begin{array}{l}\text { 55: Management of Companies } \\
\text { and Enterprises }\end{array}$ & $\begin{array}{c}0.00 \\
(0.00)\end{array}$ & $\begin{array}{l}-0.00 \\
(0.00)\end{array}$ & $\begin{array}{c}0.00 \\
(0.00)\end{array}$ & $\begin{array}{c}0.00 \\
(0.00)\end{array}$ \\
\hline $\begin{array}{l}\text { 56: Administrative Support, } \\
\text { Waste Management and } \\
\text { Remediation Services }\end{array}$ & $\begin{array}{c}0.00 \\
(0.00)\end{array}$ & $\begin{array}{c}-0.00 * * * \\
(0.00)\end{array}$ & $\begin{array}{c}0.00 \\
(0.00)\end{array}$ & $\begin{array}{c}-0.00 * * * \\
(0.00)\end{array}$ \\
\hline 61: Educational Services & $\begin{array}{l}-0.00^{*} \\
(0.00)\end{array}$ & $\begin{array}{c}0.00 \\
(0.00)\end{array}$ & $\begin{array}{c}-0.00 \\
(0.00)\end{array}$ & $\begin{array}{c}0.00 \\
(0.00)\end{array}$ \\
\hline 62: Health Care, Social Assist. & $\begin{array}{c}0.00 \\
(0.00)\end{array}$ & $\begin{array}{c}0.00 \\
(0.00)\end{array}$ & $\begin{array}{c}0.00 \\
(0.00)\end{array}$ & $\begin{array}{l}0.00 * * \\
(0.00)\end{array}$ \\
\hline $\begin{array}{l}\text { 71: Arts, Entertainment, and } \\
\text { Recreation }\end{array}$ & $\begin{array}{l}-0.00 \\
(0.00)\end{array}$ & $\begin{array}{c}-0.00^{*} \\
(0.00)\end{array}$ & $\begin{array}{l}-0.00 \\
(0.00)\end{array}$ & $\begin{array}{c}-0.00 \\
(0.00)\end{array}$ \\
\hline 72: Accommodation, Food Serv. & $\begin{array}{c}0.00 \\
(0.00)\end{array}$ & $\begin{array}{l}-0.00 \\
(0.00)\end{array}$ & $\begin{array}{l}-0.00 \\
(0.00)\end{array}$ & $\begin{array}{l}-0.00 \\
(0.00)\end{array}$ \\
\hline 81: Other Services & $\begin{array}{c}0.00 \\
(0.00)\end{array}$ & $\begin{array}{c}0.00^{* * *} \\
(0.00)\end{array}$ & $\begin{array}{c}0.00 \\
(0.00)\end{array}$ & $\begin{array}{c}0.00 * * \\
(0.00)\end{array}$ \\
\hline
\end{tabular}


Table A7. (cont'd)

\begin{tabular}{|c|c|c|c|c|}
\hline NAICS Sector Employment & $\begin{array}{c}(1) \\
\text { Income } \\
\text { Growth Rate }\end{array}$ & $\begin{array}{l}\quad(2) \\
\text { Employment } \\
\text { Growth Rate }\end{array}$ & $\begin{array}{l}\text { (3) } \\
\text { Poverty Rate } \\
\text { Growth }\end{array}$ & $\begin{array}{c}\text { (4) } \\
\text { Population } \\
\text { Growth Rate }\end{array}$ \\
\hline$\%$ of establishments under 11 : & -0.74 & $1.41^{* *}$ & 0.22 & $1.09 * *$ \\
\hline Ag., Forestry, Fishing, Hunting & $(0.86)$ & $(0.65)$ & $(0.21)$ & $(0.46)$ \\
\hline 21: Mining, Quarrying, and & -0.21 & $1.73^{* * *}$ & 0.21 & $1.46^{* * *}$ \\
\hline Oil and Gas Extraction & $(0.87)$ & $(0.65)$ & $(0.21)$ & $(0.44)$ \\
\hline 22: Utilities & $\begin{array}{l}-0.50 \\
(1.37)\end{array}$ & $\begin{array}{l}-0.05 \\
(1.17)\end{array}$ & $\begin{array}{c}0.49 \\
(0.45)\end{array}$ & $\begin{array}{c}0.25 \\
(0.82)\end{array}$ \\
\hline 23: Construction & $\begin{array}{l}-0.80 \\
(0.85)\end{array}$ & $\begin{array}{c}2.04 * * * \\
(0.65)\end{array}$ & $\begin{array}{c}0.27 \\
(0.21)\end{array}$ & $\begin{array}{c}1.95^{* * *} \\
(0.45)\end{array}$ \\
\hline 31-33: Manufacturing & $\begin{array}{l}-1.42 \\
(0.87)\end{array}$ & $\begin{array}{l}1.33^{* *} \\
(0.65)\end{array}$ & $\begin{array}{c}0.33 \\
(0.21)\end{array}$ & $\begin{array}{c}1.42 * * * \\
(0.45)\end{array}$ \\
\hline 42: Wholesale Trade & $\begin{array}{l}-0.43 \\
(0.90)\end{array}$ & $\begin{array}{l}1.71 * * \\
(0.69)\end{array}$ & $\begin{array}{c}0.30 \\
(0.21)\end{array}$ & $\begin{array}{c}1.38 * * * \\
(0.47)\end{array}$ \\
\hline 44-45: Retail Trade & $\begin{array}{l}-0.69 \\
(0.84)\end{array}$ & $\begin{array}{l}1.50^{* *} \\
(0.66)\end{array}$ & $\begin{array}{c}0.25 \\
(0.21)\end{array}$ & $\begin{array}{c}1.37 * * * \\
(0.47)\end{array}$ \\
\hline $\begin{array}{l}\text { 48-49: Transportation and } \\
\text { Warehousing }\end{array}$ & $\begin{array}{l}-0.72 \\
(0.90)\end{array}$ & $\begin{array}{c}1.87 * * * \\
(0.67)\end{array}$ & $\begin{array}{c}0.26 \\
(0.21)\end{array}$ & $\begin{array}{c}1.68^{* * *} \\
(0.45)\end{array}$ \\
\hline 51: Information & $\begin{array}{c}0.44 \\
(1.19)\end{array}$ & $\begin{array}{l}1.82^{*} \\
(1.01)\end{array}$ & $\begin{array}{c}0.00 \\
(0.27)\end{array}$ & $\begin{array}{l}1.05 \\
(0.73)\end{array}$ \\
\hline 52: Finance and Insurance & $\begin{array}{l}-0.85 \\
(0.88)\end{array}$ & $\begin{array}{l}1.54^{* *} \\
(0.62)\end{array}$ & $\begin{array}{c}0.22 \\
(0.23)\end{array}$ & $\begin{array}{c}1.41^{* * *} \\
(0.49)\end{array}$ \\
\hline $\begin{array}{l}\text { 53: Real Estate, Rental \& } \\
\text { Leasing }\end{array}$ & $\begin{array}{l}-0.36 \\
(0.85)\end{array}$ & $\begin{array}{c}2.24 * * * \\
(0.65)\end{array}$ & $\begin{array}{c}0.27 \\
(0.21)\end{array}$ & $\begin{array}{c}2.11^{* * *} \\
(0.45)\end{array}$ \\
\hline $\begin{array}{l}\text { 54: Professional, Scientific, and } \\
\text { Technical Services }\end{array}$ & $\begin{array}{l}-0.38 \\
(0.87)\end{array}$ & $\begin{array}{l}1.51^{* *} \\
(0.62)\end{array}$ & $\begin{array}{c}0.17 \\
(0.21)\end{array}$ & $\begin{array}{c}1.61^{* * *} \\
(0.45)\end{array}$ \\
\hline $\begin{array}{l}\text { 55: Management of Companies } \\
\text { and Enterprises }\end{array}$ & $\begin{array}{c}1.08 \\
(1.52)\end{array}$ & $\begin{array}{l}2.51^{*} \\
(1.35)\end{array}$ & $\begin{array}{l}-0.16 \\
(0.43)\end{array}$ & $\begin{array}{l}-0.04 \\
(1.07)\end{array}$ \\
\hline $\begin{array}{l}\text { 56: Administrative Support, } \\
\text { Waste Management and } \\
\text { Remediation Services }\end{array}$ & $\begin{array}{l}-0.43 \\
(0.87)\end{array}$ & $\begin{array}{c}2.22 * * * \\
(0.68)\end{array}$ & $\begin{array}{c}0.29 \\
(0.21)\end{array}$ & $\begin{array}{c}2.01^{* * *} \\
(0.46)\end{array}$ \\
\hline 61: Educational Services & $\begin{array}{l}-0.62 \\
(0.97)\end{array}$ & $\begin{array}{c}0.91 \\
(0.90)\end{array}$ & $\begin{array}{c}0.29 \\
(0.26)\end{array}$ & $\begin{array}{c}0.95 \\
(0.64)\end{array}$ \\
\hline 62: Health Care, Social Assist. & $\begin{array}{l}-1.01 \\
(0.88)\end{array}$ & $\begin{array}{l}1.59 * * \\
(0.65)\end{array}$ & $\begin{array}{c}0.29 \\
(0.20)\end{array}$ & $\begin{array}{c}1.53^{* * *} \\
(0.44)\end{array}$ \\
\hline $\begin{array}{l}\text { 71: Arts, Entertainment, and } \\
\text { Recreation }\end{array}$ & $\begin{array}{l}-0.67 \\
(0.83)\end{array}$ & $\begin{array}{c}1.77^{* * *} \\
(0.66)\end{array}$ & $\begin{array}{c}0.22 \\
(0.21)\end{array}$ & $\begin{array}{c}1.56^{* * *} \\
(0.52)\end{array}$ \\
\hline 72: Accommodation, Food Serv. & $\begin{array}{l}-0.26 \\
(0.94)\end{array}$ & $\begin{array}{l}1.73^{* *} \\
(0.71)\end{array}$ & $\begin{array}{c}0.24 \\
(0.22)\end{array}$ & $\begin{array}{l}1.12 * * \\
(0.47)\end{array}$ \\
\hline 81: Other Services & $\begin{array}{l}-0.73 \\
(0.87)\end{array}$ & $\begin{array}{l}1.36^{* *} \\
(0.64)\end{array}$ & $\begin{array}{c}0.23 \\
(0.21)\end{array}$ & $\begin{array}{c}1.33^{* * *} \\
(0.47)\end{array}$ \\
\hline
\end{tabular}


Table A7. (cont'd)

\begin{tabular}{|c|c|c|c|c|}
\hline State Variables & $\begin{array}{c}(1) \\
\text { Income } \\
\text { Growth Rate }\end{array}$ & $\begin{array}{c}\quad(2) \\
\text { Employment } \\
\text { Growth Rate }\end{array}$ & $\begin{array}{l}\text { (3) } \\
\text { Poverty Rate } \\
\text { Growth }\end{array}$ & $\begin{array}{c}\text { (4) } \\
\text { Population } \\
\text { Growth Rate }\end{array}$ \\
\hline Arizona & $\begin{array}{l}-0.04 * \\
(0.02)\end{array}$ & $\begin{array}{l}0.08 * \\
(0.04)\end{array}$ & $\begin{array}{c}0.01 \\
(0.01)\end{array}$ & $\begin{array}{c}0.06 \\
(0.04)\end{array}$ \\
\hline Arkansas & $\begin{array}{c}-0.04 * * * \\
(0.01)\end{array}$ & $\begin{array}{c}-0.03^{* * *} \\
(0.01)\end{array}$ & $\begin{array}{c}0.02^{* * * *} \\
(0.00)\end{array}$ & $\begin{array}{l}-0.01 \\
(0.01)\end{array}$ \\
\hline California & $\begin{array}{c}0.00 \\
(0.02)\end{array}$ & $\begin{array}{l}0.04^{*} \\
(0.02)\end{array}$ & $\begin{array}{l}-0.00 \\
(0.01)\end{array}$ & $\begin{array}{c}0.03 \\
(0.02)\end{array}$ \\
\hline Colorado & $\begin{array}{l}-0.03 \\
(0.02)\end{array}$ & $\begin{array}{l}-0.04 * \\
(0.02)\end{array}$ & $\begin{array}{c}0.01 * * \\
(0.01)\end{array}$ & $\begin{array}{c}-0.03^{* *} \\
(0.02)\end{array}$ \\
\hline Connecticut & $\begin{array}{c}0.09 * * * \\
(0.02)\end{array}$ & $\begin{array}{c}0.03 \\
(0.02)\end{array}$ & $\begin{array}{c}-0.01 * * \\
(0.01)\end{array}$ & $\begin{array}{l}-0.02 \\
(0.02)\end{array}$ \\
\hline Delaware & $\begin{array}{l}-0.00 \\
(0.04)\end{array}$ & $\begin{array}{c}0.07^{* *} \\
(0.03)\end{array}$ & $\begin{array}{c}0.00 \\
(0.01)\end{array}$ & $\begin{array}{c}0.13^{* * *} \\
(0.02)\end{array}$ \\
\hline District of Columbia & $\begin{array}{c}0.11 \\
(0.11)\end{array}$ & $\begin{array}{l}-0.04 \\
(0.10)\end{array}$ & $\begin{array}{c}-0.04 * \\
(0.02)\end{array}$ & $\begin{array}{l}-0.10 \\
(0.09)\end{array}$ \\
\hline Florida & $\begin{array}{c}-0.04 * * * \\
(0.02)\end{array}$ & $\begin{array}{c}0.08^{* * *} \\
(0.02)\end{array}$ & $\begin{array}{c}0.01^{* *} \\
(0.01)\end{array}$ & $\begin{array}{c}0.10^{* * *} \\
(0.02)\end{array}$ \\
\hline Geogia & $\begin{array}{c}-0.06^{* * * *} \\
(0.01)\end{array}$ & $\begin{array}{c}0.01 \\
(0.01)\end{array}$ & $\begin{array}{c}0.01^{* * * *} \\
(0.00)\end{array}$ & $\begin{array}{c}0.05^{* * *} \\
(0.01)\end{array}$ \\
\hline Idaho & $\begin{array}{c}-0.09 * * * \\
(0.02)\end{array}$ & $\begin{array}{c}0.00 \\
(0.02)\end{array}$ & $\begin{array}{c}0.02^{* * * *} \\
(0.01)\end{array}$ & $\begin{array}{c}0.01 \\
(0.02)\end{array}$ \\
\hline Illinois & $\begin{array}{l}-0.02 * \\
(0.01)\end{array}$ & $\begin{array}{l}-0.02 \\
(0.02)\end{array}$ & $\begin{array}{c}0.02 * * * \\
(0.00)\end{array}$ & $\begin{array}{l}-0.02 * \\
(0.01)\end{array}$ \\
\hline Indiana & $\begin{array}{c}-0.06^{* * * *} \\
(0.01)\end{array}$ & $\begin{array}{c}-0.07 * * * \\
(0.02)\end{array}$ & $\begin{array}{c}0.02^{* * * *} \\
(0.00)\end{array}$ & $\begin{array}{c}-0.05^{* * * *} \\
(0.01)\end{array}$ \\
\hline Iowa & $\begin{array}{l}-0.01 \\
(0.02)\end{array}$ & $\begin{array}{l}-0.03 \\
(0.02)\end{array}$ & $\begin{array}{c}0.01 * * \\
(0.01)\end{array}$ & $\begin{array}{c}-0.04 * * * \\
(0.01)\end{array}$ \\
\hline Kansas & $\begin{array}{c}-0.06^{* * * *} \\
(0.02)\end{array}$ & $\begin{array}{c}-0.03^{* * *} \\
(0.02)\end{array}$ & $\begin{array}{c}0.01 * * \\
(0.01)\end{array}$ & $\begin{array}{c}-0.05^{* * *} \\
(0.01)\end{array}$ \\
\hline Kentucky & $\begin{array}{l}-0.02 \\
(0.01)\end{array}$ & $\begin{array}{c}-0.03^{* * *} \\
(0.01)\end{array}$ & $\begin{array}{c}0.02^{* * *} \\
(0.00)\end{array}$ & $\begin{array}{l}-0.01 \\
(0.01)\end{array}$ \\
\hline Louisiana & $\begin{array}{c}0.06^{* * * *} \\
(0.02)\end{array}$ & $\begin{array}{c}0.02 \\
(0.02)\end{array}$ & $\begin{array}{c}-0.01^{* * *} \\
(0.01)\end{array}$ & $\begin{array}{l}-0.01 \\
(0.02)\end{array}$ \\
\hline Maine & $\begin{array}{l}-0.01 \\
(0.02)\end{array}$ & $\begin{array}{c}0.01 \\
(0.02)\end{array}$ & $\begin{array}{c}0.01 \\
(0.01)\end{array}$ & $\begin{array}{c}0.01 \\
(0.02)\end{array}$ \\
\hline Maryland & $\begin{array}{c}0.08^{* * * *} \\
(0.02)\end{array}$ & $\begin{array}{c}0.04 * * \\
(0.02)\end{array}$ & $\begin{array}{c}-0.02 * * * \\
(0.01)\end{array}$ & $\begin{array}{c}0.01 \\
(0.02)\end{array}$ \\
\hline Massachusetts & $\begin{array}{l}0.06^{*} \\
(0.03)\end{array}$ & $\begin{array}{l}-0.01 \\
(0.02)\end{array}$ & $\begin{array}{c}-0.01^{* *} \\
(0.01)\end{array}$ & $\begin{array}{c}-0.04 * * \\
(0.02)\end{array}$ \\
\hline Michigan & $\begin{array}{c}-0.09 * * * \\
(0.01)\end{array}$ & $\begin{array}{c}-0.11^{* * * *} \\
(0.02)\end{array}$ & $\begin{array}{c}0.03^{* * *} \\
(0.01)\end{array}$ & $\begin{array}{c}-0.08^{* * * *} \\
(0.01)\end{array}$ \\
\hline
\end{tabular}


Table A7. (cont'd)

\begin{tabular}{|c|c|c|c|c|}
\hline State Variables & $\begin{array}{c}\text { (1) } \\
\text { Income } \\
\text { Growth Rate }\end{array}$ & $\begin{array}{l}\text { (2) } \\
\text { Employment } \\
\text { Growth Rate }\end{array}$ & $\begin{array}{c}\text { (3) } \\
\text { Poverty Rate } \\
\text { Growth }\end{array}$ & $\begin{array}{c}\text { (4) } \\
\text { Population } \\
\text { Growth Rate }\end{array}$ \\
\hline Minnesota & $\begin{array}{l}-0.01 \\
(0.02)\end{array}$ & $\begin{array}{c}0.00 \\
(0.02)\end{array}$ & $\begin{array}{c}0.01 * * * \\
(0.01)\end{array}$ & $\begin{array}{l}-0.02 * \\
(0.01)\end{array}$ \\
\hline Mississippi & $\begin{array}{c}-0.03^{* *} \\
(0.01)\end{array}$ & $\begin{array}{l}-0.03^{*} \\
(0.02)\end{array}$ & $\begin{array}{c}0.01 * * * \\
(0.00)\end{array}$ & $\begin{array}{l}-0.01 \\
(0.01)\end{array}$ \\
\hline Missouri & $\begin{array}{c}-0.04 * * * \\
(0.01)\end{array}$ & $\begin{array}{c}0.00 \\
(0.01)\end{array}$ & $\begin{array}{c}0.01 * * * \\
(0.00)\end{array}$ & $\begin{array}{c}0.00 \\
(0.01)\end{array}$ \\
\hline Montana & $\begin{array}{l}-0.03 * \\
(0.02)\end{array}$ & $\begin{array}{c}0.01 \\
(0.02)\end{array}$ & $\begin{array}{c}0.01 \\
(0.01)\end{array}$ & $\begin{array}{c}0.02 \\
(0.02)\end{array}$ \\
\hline Nebraska & $\begin{array}{c}-0.04 * * \\
(0.02)\end{array}$ & $\begin{array}{l}-0.01 \\
(0.02)\end{array}$ & $\begin{array}{l}0.01^{* *} \\
(0.01)\end{array}$ & $\begin{array}{c}-0.03 * * \\
(0.01)\end{array}$ \\
\hline Nevada & $\begin{array}{l}-0.03 \\
(0.04)\end{array}$ & $\begin{array}{c}0.05 \\
(0.03)\end{array}$ & $\begin{array}{l}0.02 * \\
(0.01)\end{array}$ & $\begin{array}{c}0.06 \\
(0.04)\end{array}$ \\
\hline New Hampshire & $\begin{array}{c}0.00 \\
(0.02)\end{array}$ & $\begin{array}{l}-0.00 \\
(0.02)\end{array}$ & $\begin{array}{l}-0.00 \\
(0.01)\end{array}$ & $\begin{array}{c}-0.04 * * \\
(0.02)\end{array}$ \\
\hline New Jersey & $\begin{array}{c}0.05^{* * *} \\
(0.02)\end{array}$ & $\begin{array}{l}-0.04^{*} \\
(0.02)\end{array}$ & $\begin{array}{l}-0.00 \\
(0.01)\end{array}$ & $\begin{array}{c}-0.07 * * * \\
(0.02)\end{array}$ \\
\hline New Mexico & $\begin{array}{l}-0.03 \\
(0.03)\end{array}$ & $\begin{array}{c}0.02 \\
(0.03)\end{array}$ & $\begin{array}{l}-0.00 \\
(0.01)\end{array}$ & $\begin{array}{c}0.02 \\
(0.02)\end{array}$ \\
\hline New York & $\begin{array}{l}-0.01 \\
(0.02)\end{array}$ & $\begin{array}{l}-0.01 \\
(0.02)\end{array}$ & $\begin{array}{c}0.00 \\
(0.01)\end{array}$ & $\begin{array}{l}-0.02 \\
(0.01)\end{array}$ \\
\hline North Carolina & $\begin{array}{c}-0.03 * * \\
(0.01)\end{array}$ & $\begin{array}{l}-0.01 \\
(0.01)\end{array}$ & $\begin{array}{c}0.02 * * * \\
(0.00)\end{array}$ & $\begin{array}{c}0.04 * * * \\
(0.01)\end{array}$ \\
\hline North Dakota & $\begin{array}{c}0.06 * * * \\
(0.02)\end{array}$ & $\begin{array}{c}0.02 \\
(0.02)\end{array}$ & $\begin{array}{c}0.00 \\
(0.01)\end{array}$ & $\begin{array}{c}-0.04^{* *} \\
(0.02)\end{array}$ \\
\hline Ohio & $\begin{array}{c}-0.06^{* * *} \\
(0.01)\end{array}$ & $\begin{array}{c}-0.06^{* * * *} \\
(0.02)\end{array}$ & $\begin{array}{c}0.02 * * * \\
(0.01)\end{array}$ & $\begin{array}{c}-0.05 * * * \\
(0.01)\end{array}$ \\
\hline Oklahoma & $\begin{array}{c}-0.04^{* *} \\
(0.02)\end{array}$ & $\begin{array}{c}0.01 \\
(0.02)\end{array}$ & $\begin{array}{l}0.01 * \\
(0.01)\end{array}$ & $\begin{array}{c}0.01 \\
(0.01)\end{array}$ \\
\hline Oregon & $\begin{array}{c}-0.05^{* * * *} \\
(0.02)\end{array}$ & $\begin{array}{c}0.01 \\
(0.02)\end{array}$ & $\begin{array}{c}0.02 * * * \\
(0.01)\end{array}$ & $\begin{array}{c}0.02 \\
(0.02)\end{array}$ \\
\hline Pennsylvania & $\begin{array}{l}-0.02 \\
(0.02)\end{array}$ & $\begin{array}{c}0.00 \\
(0.02)\end{array}$ & $\begin{array}{l}-0.00 \\
(0.01)\end{array}$ & $\begin{array}{l}-0.01 \\
(0.01)\end{array}$ \\
\hline Rhode Island & $\begin{array}{c}0.05 * * * \\
(0.02)\end{array}$ & $\begin{array}{l}-0.05^{*} \\
(0.03)\end{array}$ & $\begin{array}{c}-0.02^{* * *} \\
(0.01)\end{array}$ & $\begin{array}{c}-0.10 * * * \\
(0.02)\end{array}$ \\
\hline South Carolina & $\begin{array}{c}-0.04^{* * *} \\
(0.01)\end{array}$ & $\begin{array}{l}-0.01 \\
(0.02)\end{array}$ & $\begin{array}{c}0.02 * * * \\
(0.01)\end{array}$ & $\begin{array}{c}0.04 * * * \\
(0.01)\end{array}$ \\
\hline South Dakota & $\begin{array}{c}0.01 \\
(0.02)\end{array}$ & $\begin{array}{c}0.01 \\
(0.02)\end{array}$ & $\begin{array}{c}0.01 \\
(0.01)\end{array}$ & $\begin{array}{l}-0.02 \\
(0.02)\end{array}$ \\
\hline Tennessee & $\begin{array}{c}-0.03^{* *} \\
(0.01)\end{array}$ & $\begin{array}{c}-0.04^{* * *} \\
(0.01)\end{array}$ & $\begin{array}{c}0.02 * * * \\
(0.00)\end{array}$ & $\begin{array}{c}0.00 \\
(0.01)\end{array}$ \\
\hline
\end{tabular}


Table A7. (cont'd)

\begin{tabular}{|c|c|c|c|c|}
\hline State Variables & $\begin{array}{c}\text { (1) } \\
\text { Income } \\
\text { Growth Rate }\end{array}$ & $\begin{array}{l}\text { (2) } \\
\text { Employment } \\
\text { Growth Rate }\end{array}$ & $\begin{array}{c}\text { (3) } \\
\text { Poverty Rate } \\
\text { Growth }\end{array}$ & $\begin{array}{c}\text { (4) } \\
\text { Population } \\
\text { Growth Rate }\end{array}$ \\
\hline Texas & $\begin{array}{l}-0.03^{*} \\
(0.01)\end{array}$ & $\begin{array}{c}0.03 * * \\
(0.01)\end{array}$ & $\begin{array}{c}0.01 \\
(0.00)\end{array}$ & $\begin{array}{c}0.01 \\
(0.01)\end{array}$ \\
\hline Utah & $\begin{array}{c}-0.07 * * * \\
(0.03)\end{array}$ & $\begin{array}{l}-0.01 \\
(0.03)\end{array}$ & $\begin{array}{l}-0.01 \\
(0.01)\end{array}$ & $\begin{array}{c}0.01 \\
(0.02)\end{array}$ \\
\hline Vermont & $\begin{array}{c}0.00 \\
(0.02)\end{array}$ & $\begin{array}{l}-0.02 \\
(0.02)\end{array}$ & $\begin{array}{l}-0.00 \\
(0.01)\end{array}$ & $\begin{array}{c}-0.05 * * * \\
(0.02)\end{array}$ \\
\hline Virginia & $\begin{array}{c}0.03^{* * *} \\
(0.01)\end{array}$ & $\begin{array}{c}0.01 \\
(0.02)\end{array}$ & $\begin{array}{l}-0.01^{*} \\
(0.00)\end{array}$ & $\begin{array}{c}0.01 \\
(0.01)\end{array}$ \\
\hline Washington & $\begin{array}{c}-0.04^{* *} \\
(0.02)\end{array}$ & $\begin{array}{l}0.04^{*} \\
(0.02)\end{array}$ & $\begin{array}{c}0.02 * * * \\
(0.01)\end{array}$ & $\begin{array}{c}0.06^{* * * *} \\
(0.02)\end{array}$ \\
\hline West Virginia & $\begin{array}{c}-0.04^{* *} \\
(0.02)\end{array}$ & $\begin{array}{c}0.02 \\
(0.02)\end{array}$ & $\begin{array}{c}0.00 \\
(0.01)\end{array}$ & $\begin{array}{c}0.01 \\
(0.01)\end{array}$ \\
\hline Wisconsin & $\begin{array}{c}-0.03^{* *} \\
(0.02)\end{array}$ & $\begin{array}{l}-0.01 \\
(0.02)\end{array}$ & $\begin{array}{c}0.02^{* * *} \\
(0.01)\end{array}$ & $\begin{array}{l}-0.01 \\
(0.01)\end{array}$ \\
\hline Wyoming & $\begin{array}{l}0.04^{*} \\
(0.02)\end{array}$ & $\begin{array}{c}0.08^{* * * *} \\
(0.03)\end{array}$ & $\begin{array}{c}-0.01 * * \\
(0.01)\end{array}$ & $\begin{array}{c}0.06 * * \\
(0.02)\end{array}$ \\
\hline Constant & $\begin{array}{l}-0.22 \\
(0.87)\end{array}$ & $\begin{array}{c}-1.56 * * \\
(0.66)\end{array}$ & $\begin{array}{c}0.09 \\
(0.21)\end{array}$ & $\begin{array}{c}-1.21 * * \\
(0.48)\end{array}$ \\
\hline $\begin{array}{l}\text { Observations } \\
R^{2}\end{array}$ & $\begin{array}{c}\sim 3,100 \\
0.48\end{array}$ & $\begin{array}{c}\sim 3,100 \\
0.49\end{array}$ & $\begin{array}{c}\sim 3,100 \\
0.43\end{array}$ & $\begin{array}{c}\sim 3,100 \\
0.64\end{array}$ \\
\hline
\end{tabular}

Robust standard errors in parentheses

*** $\mathrm{p}<0.01, * * \mathrm{p}<0.05,{ }^{*} \mathrm{p}<0.1$ 
Table A8. OLS Regressions of Economic Performance on 2002 Industry LOB Employment Share

\begin{tabular}{|c|c|c|c|c|}
\hline NAICS Sector & $\begin{array}{c}\text { (1) } \\
\text { Income } \\
\text { Growth Rate }\end{array}$ & $\begin{array}{l}\text { (2) } \\
\text { Employment } \\
\text { Growth Rate }\end{array}$ & $\begin{array}{c}\text { (3) } \\
\text { Poverty Rate } \\
\text { Growth } \\
\end{array}$ & $\begin{array}{c}\text { (4) } \\
\text { Population } \\
\text { Growth Rate }\end{array}$ \\
\hline LOB share in 11: Agriculture, & -0.01 & $0.05^{* *}$ & 0.00 & 0.02 \\
\hline Forestry, Fishing and Hunting & $(0.02)$ & $(0.02)$ & $(0.01)$ & $(0.02)$ \\
\hline 21: Mining, Quarrying, and & 0.02 & -0.05 & 0.02 & -0.03 \\
\hline Oil and Gas Extraction & $(0.03)$ & $(0.03)$ & $(0.01)$ & $(0.03)$ \\
\hline \multirow[t]{2}{*}{ 22: Utilities } & $0.16^{*}$ & -0.08 & $-0.08 * * *$ & -0.13 \\
\hline & $(0.09)$ & $(0.13)$ & $(0.03)$ & $(0.13)$ \\
\hline \multirow[t]{2}{*}{ 23: Construction } & 0.04 & -0.02 & 0.00 & -0.02 \\
\hline & $(0.03)$ & $(0.03)$ & $(0.01)$ & $(0.02)$ \\
\hline \multirow[t]{2}{*}{ 31-33: Manufacturing } & -0.04 & -0.00 & -0.01 & 0.02 \\
\hline & $(0.04)$ & $(0.04)$ & $(0.02)$ & $(0.03)$ \\
\hline \multirow[t]{2}{*}{ 42: Wholesale Trade } & 0.06 & 0.02 & 0.00 & 0.03 \\
\hline & $(0.06)$ & $(0.06)$ & $(0.01)$ & $(0.05)$ \\
\hline \multirow[t]{2}{*}{ 44-45: Retail Trade } & 0.04 & 0.07 & 0.03 & 0.02 \\
\hline & $(0.07)$ & $(0.06)$ & $(0.04)$ & $(0.03)$ \\
\hline 48-49: Transportation and & -0.00 & 0.00 & 0.00 & 0.01 \\
\hline Warehousing & $(0.02)$ & $(0.03)$ & $(0.01)$ & $(0.02)$ \\
\hline \multirow[t]{2}{*}{ 51: Information } & 0.01 & -0.10 & $-0.03 *$ & $-0.19 * *$ \\
\hline & $(0.04)$ & $(0.08)$ & $(0.02)$ & $(0.08)$ \\
\hline \multirow[t]{2}{*}{ 52: Finance and Insurance } & -0.07 & -0.03 & -0.03 & $-0.06^{*}$ \\
\hline & $(0.06)$ & $(0.05)$ & $(0.04)$ & $(0.04)$ \\
\hline 53: Real Estate, Rental \& & $-0.05 *$ & $-0.07 * *$ & $0.02 * *$ & -0.02 \\
\hline Leasing & $(0.03)$ & $(0.03)$ & $(0.01)$ & $(0.03)$ \\
\hline 54: Professional, Scientific, and & $0.08 * * *$ & 0.02 & 0.00 & -0.04 \\
\hline Technical Services & $(0.03)$ & $(0.03)$ & $(0.01)$ & $(0.03)$ \\
\hline 55: Management of Companies & $0.12 * * *$ & 0.06 & -0.01 & -0.05 \\
\hline and Enterprises & $(0.03)$ & $(0.05)$ & $(0.01)$ & $(0.03)$ \\
\hline 56: Administrative Support, & 0.03 & -0.01 & -0.02 & -0.01 \\
\hline Waste Management and & $(0.04)$ & $(0.05)$ & $(0.01)$ & $(0.02)$ \\
\hline \multicolumn{5}{|l|}{ Remediation Services } \\
\hline \multirow[t]{2}{*}{ 61: Educational Services } & 0.00 & -0.10 & $-0.01 *$ & 0.00 \\
\hline & $(0.03)$ & $(0.11)$ & $(0.01)$ & $(0.04)$ \\
\hline \multirow[t]{2}{*}{ 62: Health Care, Social Assist. } & -0.00 & 0.02 & -0.02 & $-0.03 *$ \\
\hline & $(0.06)$ & $(0.03)$ & $(0.02)$ & $(0.02)$ \\
\hline 71: Arts, Entertainment, and & 0.02 & 0.05 & -0.00 & 0.01 \\
\hline Recreation & $(0.02)$ & $(0.03)$ & $(0.01)$ & $(0.02)$ \\
\hline \multirow[t]{2}{*}{ 72: Accommodation, Food Serv. } & 0.00 & 0.02 & -0.00 & 0.00 \\
\hline & $(0.03)$ & $(0.02)$ & $(0.01)$ & $(0.02)$ \\
\hline \multirow[t]{2}{*}{ 81: Other Services } & -0.04 & -0.01 & 0.01 & -0.02 \\
\hline & $(0.03)$ & $(0.03)$ & $(0.01)$ & $(0.02)$ \\
\hline
\end{tabular}


Table A8. (cont'd)

\begin{tabular}{|c|c|c|c|c|}
\hline County Variables & $\begin{array}{c}(1) \\
\text { Income } \\
\text { Growth Rate }\end{array}$ & $\begin{array}{l}\quad(2) \\
\text { Employment } \\
\text { Growth Rate }\end{array}$ & $\begin{array}{c}(3) \\
\text { Poverty Rate } \\
\text { Growth }\end{array}$ & $\begin{array}{c}\text { (4) } \\
\text { Population } \\
\text { Growth Rate }\end{array}$ \\
\hline Per capita income & $\begin{array}{c}-0.00 * * * \\
(0.00)\end{array}$ & $\begin{array}{c}-0.00 * * * \\
(0.00)\end{array}$ & $\begin{array}{c}-0.00 * * \\
(0.00)\end{array}$ & $\begin{array}{l}-0.00 \\
(0.00)\end{array}$ \\
\hline Employment & $\begin{array}{l}-0.00 \\
(0.00)\end{array}$ & $\begin{array}{c}-0.00^{* *} \\
(0.00)\end{array}$ & $\begin{array}{c}0.00^{* *} \\
(0.00)\end{array}$ & $\begin{array}{l}-0.00 \\
(0.00)\end{array}$ \\
\hline Poverty rate & $\begin{array}{c}0.29 * * * \\
(0.09)\end{array}$ & $\begin{array}{l}-0.07 \\
(0.09)\end{array}$ & $\begin{array}{c}-0.48^{* * * *} \\
(0.03)\end{array}$ & $\begin{array}{c}-0.14^{*} \\
(0.07)\end{array}$ \\
\hline Population & $\begin{array}{c}0.00 \\
(0.00)\end{array}$ & $\begin{array}{l}-0.00 \\
(0.00)\end{array}$ & $\begin{array}{c}-0.00^{* * * *} \\
(0.00)\end{array}$ & $\begin{array}{c}-0.00 * * \\
(0.00)\end{array}$ \\
\hline Population squared & $\begin{array}{c}0.00 \\
(0.00)\end{array}$ & $\begin{array}{l}-0.00 \\
(0.00)\end{array}$ & $\begin{array}{c}0.00^{* * *} \\
(0.00)\end{array}$ & $\begin{array}{l}-0.00 \\
(0.00)\end{array}$ \\
\hline Population density & $\begin{array}{c}0.00^{* *} \\
(0.00)\end{array}$ & $\begin{array}{c}-0.00 \\
(0.00)\end{array}$ & $\begin{array}{l}-0.00 \\
(0.00)\end{array}$ & $\begin{array}{c}-0.00^{* *} \\
(0.00)\end{array}$ \\
\hline Average household size & $\begin{array}{c}0.10^{* * *} \\
(0.02)\end{array}$ & $\begin{array}{c}0.12^{* * *} \\
(0.02)\end{array}$ & $\begin{array}{l}-0.00 \\
(0.01)\end{array}$ & $\begin{array}{c}0.06^{* * *} \\
(0.02)\end{array}$ \\
\hline$\%$ headed by single female & $\begin{array}{c}-0.59 * * * \\
(0.08)\end{array}$ & $\begin{array}{c}-0.38^{* * *} \\
(0.09)\end{array}$ & $\begin{array}{c}0.29 * * * \\
(0.03)\end{array}$ & $\begin{array}{c}-0.47 * * * \\
(0.07)\end{array}$ \\
\hline Median age & $\begin{array}{c}0.03^{* * * *} \\
(0.01)\end{array}$ & $\begin{array}{c}-0.01^{*} \\
(0.01)\end{array}$ & $\begin{array}{c}-0.01 * * * \\
(0.00)\end{array}$ & $\begin{array}{c}-0.01 \\
(0.01)\end{array}$ \\
\hline Median age squared & $\begin{array}{c}-0.00 * * * \\
(0.00)\end{array}$ & $\begin{array}{c}0.00 \\
(0.00)\end{array}$ & $\begin{array}{c}0.00^{* * *} \\
(0.00)\end{array}$ & $\begin{array}{c}0.00 \\
(0.00)\end{array}$ \\
\hline Female population & $\begin{array}{l}-0.00 \\
(0.00)\end{array}$ & $\begin{array}{l}0.00^{*} \\
(0.00)\end{array}$ & $\begin{array}{c}0.00^{* * *} \\
(0.00)\end{array}$ & $\begin{array}{c}0.00^{* *} \\
(0.00)\end{array}$ \\
\hline Female population squared & $\begin{array}{l}-0.00 \\
(0.00)\end{array}$ & $\begin{array}{c}0.00 \\
(0.00)\end{array}$ & $\begin{array}{c}-0.00^{* * *} \\
(0.00)\end{array}$ & $\begin{array}{c}0.00 \\
(0.00)\end{array}$ \\
\hline Asian population & $\begin{array}{l}-0.00 \\
(0.00)\end{array}$ & $\begin{array}{c}0.00 \\
(0.00)\end{array}$ & $\begin{array}{c}0.00 \\
(0.00)\end{array}$ & $\begin{array}{c}0.00 \\
(0.00)\end{array}$ \\
\hline Asian population squared & $\begin{array}{c}0.00 \\
(0.00)\end{array}$ & $\begin{array}{c}0.00 \\
(0.00)\end{array}$ & $\begin{array}{c}0.00 \\
(0.00)\end{array}$ & $\begin{array}{c}0.00 \\
(0.00)\end{array}$ \\
\hline Black population & $\begin{array}{c}0.00 \\
(0.00)\end{array}$ & $\begin{array}{c}-0.00^{*} \\
(0.00)\end{array}$ & $\begin{array}{c}-0.00 * * * \\
(0.00)\end{array}$ & $\begin{array}{c}-0.00 * * * \\
(0.00)\end{array}$ \\
\hline Black population squared & $\begin{array}{l}-0.00 \\
(0.00)\end{array}$ & $\begin{array}{c}0.00 \\
(0.00)\end{array}$ & $\begin{array}{c}0.00^{* * *} \\
(0.00)\end{array}$ & $\begin{array}{c}0.00^{* * *} \\
(0.00)\end{array}$ \\
\hline Hispanic population & $\begin{array}{c}-0.00^{* * * *} \\
(0.00)\end{array}$ & $\begin{array}{l}0.00^{*} \\
(0.00)\end{array}$ & $\begin{array}{l}0.00^{*} \\
(0.00)\end{array}$ & $\begin{array}{c}0.00^{* *} \\
(0.00)\end{array}$ \\
\hline Hispanic population squared & $\begin{array}{l}-0.00 \\
(0.00)\end{array}$ & $\begin{array}{l}-0.00 \\
(0.00)\end{array}$ & $\begin{array}{c}0.00 \\
(0.00)\end{array}$ & $\begin{array}{c}0.00 \\
(0.00)\end{array}$ \\
\hline
\end{tabular}


Table A8. (cont'd)

\begin{tabular}{|c|c|c|c|c|}
\hline County Variables & $\begin{array}{c}(1) \\
\text { Income } \\
\text { Growth Rate }\end{array}$ & $\begin{array}{c}\quad(2) \\
\text { Employment } \\
\text { Growth Rate }\end{array}$ & $\begin{array}{c}(3) \\
\text { Poverty Rate } \\
\text { Growth }\end{array}$ & $\begin{array}{c}\text { (4) } \\
\text { Population } \\
\text { Growth Rate }\end{array}$ \\
\hline \% with education: High school & $\begin{array}{c}0.30^{* * *} \\
(0.07)\end{array}$ & $\begin{array}{c}0.14^{* *} \\
(0.07)\end{array}$ & $\begin{array}{c}-0.07 * * * \\
(0.02)\end{array}$ & $\begin{array}{c}0.04 \\
(0.05)\end{array}$ \\
\hline Some college & $\begin{array}{c}0.35^{* * *} \\
(0.08)\end{array}$ & $\begin{array}{c}0.25^{* * *} \\
(0.08)\end{array}$ & $\begin{array}{c}-0.08 * * * \\
(0.03)\end{array}$ & $\begin{array}{c}0.21^{* * * *} \\
(0.07)\end{array}$ \\
\hline Associates degree & $\begin{array}{c}0.74^{* * * *} \\
(0.16)\end{array}$ & $\begin{array}{c}0.24 \\
(0.15)\end{array}$ & $\begin{array}{c}-0.21 * * * \\
(0.05)\end{array}$ & $\begin{array}{l}-0.16 \\
(0.12)\end{array}$ \\
\hline Bachelor's degree & $\begin{array}{c}0.74^{* * * *} \\
(0.12)\end{array}$ & $\begin{array}{c}0.59^{* * *} \\
(0.13)\end{array}$ & $\begin{array}{c}-0.11^{* * * *} \\
(0.03)\end{array}$ & $\begin{array}{c}0.33^{* *} \\
(0.14)\end{array}$ \\
\hline graduate school degree & $\begin{array}{c}0.72^{* * * *} \\
(0.15)\end{array}$ & $\begin{array}{c}0.23 \\
(0.18)\end{array}$ & $\begin{array}{c}0.06 \\
(0.04)\end{array}$ & $\begin{array}{c}0.16 \\
(0.15)\end{array}$ \\
\hline \% owner's education: High school & $\begin{array}{c}0.00 \\
(0.00)\end{array}$ & $\begin{array}{l}0.00^{*} \\
(0.00)\end{array}$ & $\begin{array}{c}-0.00^{*} \\
(0.00)\end{array}$ & $\begin{array}{c}0.00 \\
(0.00)\end{array}$ \\
\hline Some college & $\begin{array}{l}0.00^{*} \\
(0.00)\end{array}$ & $\begin{array}{l}-0.00 \\
(0.00)\end{array}$ & $\begin{array}{l}-0.00 \\
(0.00)\end{array}$ & $\begin{array}{c}-0.00 \\
(0.00)\end{array}$ \\
\hline Trade school degree & $\begin{array}{c}0.00 \\
(0.00)\end{array}$ & $\begin{array}{l}-0.00 \\
(0.00)\end{array}$ & $\begin{array}{l}-0.00 \\
(0.00)\end{array}$ & $\begin{array}{l}-0.00 \\
(0.00)\end{array}$ \\
\hline Associates degree & $\begin{array}{c}0.00 \\
(0.00)\end{array}$ & $\begin{array}{l}-0.00 \\
(0.00)\end{array}$ & $\begin{array}{c}0.00 \\
(0.00)\end{array}$ & $\begin{array}{l}-0.00 \\
(0.00)\end{array}$ \\
\hline Bachelor's degree & $\begin{array}{l}-0.00 \\
(0.00)\end{array}$ & $\begin{array}{c}0.00 \\
(0.00)\end{array}$ & $\begin{array}{c}0.00 \\
(0.00)\end{array}$ & $\begin{array}{c}0.00 \\
(0.00)\end{array}$ \\
\hline Graduate school degree & $\begin{array}{l}0.00^{*} \\
(0.00)\end{array}$ & $\begin{array}{c}0.00 \\
(0.00)\end{array}$ & $\begin{array}{c}0.00 \\
(0.00)\end{array}$ & $\begin{array}{c}0.00 \\
(0.00)\end{array}$ \\
\hline Taxes per capita & $\begin{array}{l}-0.00 \\
(0.00)\end{array}$ & $\begin{array}{l}-0.00 \\
(0.00)\end{array}$ & $\begin{array}{c}0.00 \\
(0.00)\end{array}$ & $\begin{array}{c}-0.00^{*} \\
(0.00)\end{array}$ \\
\hline Education spending & $\begin{array}{l}-0.00 \\
(0.00)\end{array}$ & $\begin{array}{c}0.00 \\
(0.00)\end{array}$ & $\begin{array}{c}0.00 \\
(0.00)\end{array}$ & $\begin{array}{l}-0.00 \\
(0.00)\end{array}$ \\
\hline Highway spending & $\begin{array}{c}0.00 \\
(0.00)\end{array}$ & $\begin{array}{l}-0.00 \\
(0.00)\end{array}$ & $\begin{array}{l}-0.00 \\
(0.00)\end{array}$ & $\begin{array}{c}0.00 \\
(0.00)\end{array}$ \\
\hline Labor force participation rate & $\begin{array}{c}0.25^{* * * *} \\
(0.04)\end{array}$ & $\begin{array}{c}-0.14 * * \\
(0.07)\end{array}$ & $\begin{array}{c}-0.04 * * * \\
(0.01)\end{array}$ & $\begin{array}{l}-0.03 \\
(0.05)\end{array}$ \\
\hline Build permits & $\begin{array}{l}-0.00^{*} \\
(0.00)\end{array}$ & $\begin{array}{c}0.00^{* * * *} \\
(0.00)\end{array}$ & $\begin{array}{c}0.00 \\
(0.00)\end{array}$ & $\begin{array}{c}0.00^{* * *} \\
(0.00)\end{array}$ \\
\hline
\end{tabular}


Table A8. (cont'd)

\begin{tabular}{lcccc}
\hline \multirow{2}{*}{ County Variables } & $\begin{array}{c}(1) \\
\text { Income }\end{array}$ & $\begin{array}{c}(2) \\
\text { Employment }\end{array}$ & $\begin{array}{c}(3) \\
\text { Poverty Rate }\end{array}$ & $\begin{array}{c}(4) \\
\text { Population } \\
\text { Growth Rate }\end{array}$ \\
& Growth Rate & Growth Rate & Growth & Growth \\
& -0.00 & $-0.01^{* * *}$ & $0.00^{*}$ & $-0.00^{*}$ \\
Amenities & $(0.00)$ & $(0.00)$ & $(0.00)$ & $(0.00)$ \\
& -0.01 & $-0.02^{*}$ & 0.00 & $-0.02^{* *}$ \\
Rural-urban code 2 & $(0.00)$ & $(0.01)$ & $(0.00)$ & $(0.01)$ \\
Metro area, 0.25 to 1 million pop. & $-0.02^{* * *}$ & -0.01 & 0.00 & $-0.02^{* *}$ \\
Rural-urban code 3 & $(0.01)$ & $(0.01)$ & $(0.00)$ & $(0.01)$ \\
Metro area, < 250,000 & $-0.03^{* * *}$ & $-0.03^{* * *}$ & $0.01^{* * *}$ & $-0.03^{* * *}$ \\
Rural-urban code 4 & $(0.01)$ & $(0.01)$ & $(0.00)$ & $(0.01)$ \\
Adjacent to metro, $\geq 20,000$ & $-0.02^{* * *}$ & -0.01 & $0.01 * *$ & $-0.02^{* *}$ \\
Rural-urban code 5 & $(0.01)$ & $(0.01)$ & $(0.00)$ & $(0.01)$ \\
Not adjacent to metro, $\geq 20,000$ & $-0.03^{* * *}$ & $-0.02^{* *}$ & $0.01^{* * *}$ & $-0.02^{* * *}$ \\
Rural-urban code 6 & $(0.01)$ & $(0.01)$ & $(0.00)$ & $(0.01)$ \\
Adjacent to metro, 2,500-19,999 & $-0.02^{* * *}$ & $-0.02^{* *}$ & $0.01^{* * *}$ & $-0.03^{* * *}$ \\
Rural-urban code 7 & $(0.01)$ & $(0.01)$ & $(0.00)$ & $(0.01)$ \\
Not adjacent to metro, 2,500-19,999 & $-0.03^{* * *}$ & $-0.02^{*}$ & $0.01^{* * *}$ & $-0.02^{*}$ \\
Rural-urban code 8 & $(0.01)$ & $(0.01)$ & $(0.00)$ & $(0.01)$ \\
Adjacent to a metro, $<2,500$ & $-0.03^{* * *}$ & $-0.02^{* *}$ & $0.01^{* * *}$ & $-0.02^{* *}$ \\
Rural-urban code 9 & $(0.01)$ & $(0.01)$ & $(0.00)$ & $(0.01)$ \\
Not adjacent to a metro, $<2,500$ & & & &
\end{tabular}


Table A8. (cont'd)

\begin{tabular}{|c|c|c|c|c|}
\hline NAICS Sector & $\begin{array}{c}(1) \\
\text { Income } \\
\text { Growth Rate }\end{array}$ & $\begin{array}{l}\text { (2) } \\
\text { Employment } \\
\text { Growth Rate }\end{array}$ & $\begin{array}{l}\text { (3) } \\
\text { Poverty Rate } \\
\text { Growth }\end{array}$ & $\begin{array}{c}\text { (4) } \\
\text { Population } \\
\text { Growth Rate }\end{array}$ \\
\hline Employment under 11: Ag., & 0.00 & 0.00 & 0.00 & 0.00 \\
\hline Forestry, Fishing, Hunting & $(0.00)$ & $(0.00)$ & $(0.00)$ & $(0.00)$ \\
\hline 21: Mining, Quarrying, and & 0.00 & 0.00 & -0.00 & 0.00 \\
\hline Oil and Gas Extraction & $(0.00)$ & $(0.00)$ & $(0.00)$ & $(0.00)$ \\
\hline 22: Utilities & $\begin{array}{l}0.00^{*} \\
(0.00)\end{array}$ & $\begin{array}{c}0.00^{* * *} \\
(0.00)\end{array}$ & $\begin{array}{l}-0.00 \\
(0.00)\end{array}$ & $\begin{array}{c}0.00 \\
(0.00)\end{array}$ \\
\hline 23: Construction & $\begin{array}{l}-0.00 \\
(0.00)\end{array}$ & $\begin{array}{c}-0.00^{* * * *} \\
(0.00)\end{array}$ & $\begin{array}{c}0.00 \\
(0.00)\end{array}$ & $\begin{array}{c}-0.00 * * * \\
(0.00)\end{array}$ \\
\hline 31-33: Manufacturing & $\begin{array}{c}-0.00^{* * * *} \\
(0.00)\end{array}$ & $\begin{array}{c}0.00 \\
(0.00)\end{array}$ & $\begin{array}{c}0.00^{* *} \\
(0.00)\end{array}$ & $\begin{array}{c}0.00 \\
(0.00)\end{array}$ \\
\hline 42: Wholesale Trade & $\begin{array}{l}-0.00 \\
(0.00)\end{array}$ & $\begin{array}{c}0.00 \\
(0.00)\end{array}$ & $\begin{array}{c}-0.00^{*} \\
(0.00)\end{array}$ & $\begin{array}{l}-0.00 \\
(0.00)\end{array}$ \\
\hline 44-45: Retail Trade & $\begin{array}{c}-0.00^{*} \\
(0.00)\end{array}$ & $\begin{array}{l}-0.00 \\
(0.00)\end{array}$ & $\begin{array}{c}0.00 \\
(0.00)\end{array}$ & $\begin{array}{c}-0.00^{*} \\
(0.00)\end{array}$ \\
\hline $\begin{array}{l}\text { 48-49: Transportation and } \\
\text { Warehousing }\end{array}$ & $\begin{array}{c}0.00 \\
(0.00)\end{array}$ & $\begin{array}{c}0.00 \\
(0.00)\end{array}$ & $\begin{array}{c}0.00 \\
(0.00)\end{array}$ & $\begin{array}{c}0.00 \\
(0.00)\end{array}$ \\
\hline 51: Information & $\begin{array}{c}0.00 \\
(0.00)\end{array}$ & $\begin{array}{c}-0.00 * * \\
(0.00)\end{array}$ & $\begin{array}{c}0.00^{* *} \\
(0.00)\end{array}$ & $\begin{array}{c}-0.00^{* * *} \\
(0.00)\end{array}$ \\
\hline 52: Finance and Insurance & $\begin{array}{l}-0.00 * \\
(0.00)\end{array}$ & $\begin{array}{r}-0.00 \\
(0.00)\end{array}$ & $\begin{array}{c}0.00 \\
(0.00)\end{array}$ & $\begin{array}{c}0.00 \\
(0.00)\end{array}$ \\
\hline $\begin{array}{l}\text { 53: Real Estate, Rental \& } \\
\text { Leasing }\end{array}$ & $\begin{array}{c}0.00 \\
(0.00)\end{array}$ & $\begin{array}{l}0.00^{*} \\
(0.00)\end{array}$ & $\begin{array}{l}-0.00 \\
(0.00)\end{array}$ & $\begin{array}{c}0.00 \\
(0.00)\end{array}$ \\
\hline $\begin{array}{l}\text { 54: Professional, Scientific, and } \\
\text { Technical Services }\end{array}$ & $\begin{array}{c}0.00 \\
(0.00)\end{array}$ & $\begin{array}{c}0.00 * * * \\
(0.00)\end{array}$ & $\begin{array}{l}-0.00^{*} \\
(0.00)\end{array}$ & $\begin{array}{c}0.00 \\
(0.00)\end{array}$ \\
\hline $\begin{array}{l}\text { Technical Services } \\
\text { 55: Management of Companies } \\
\text { and Enterprises }\end{array}$ & $\begin{array}{c}(0.00) \\
0.00 \\
(0.00)\end{array}$ & $\begin{array}{l}-0.00 \\
(0.00)\end{array}$ & $\begin{array}{c}0.00 \\
(0.00)\end{array}$ & $\begin{array}{c}0.00 \\
(0.00)\end{array}$ \\
\hline $\begin{array}{l}\text { 56: Administrative Support, } \\
\text { Waste Management and } \\
\text { Remediation Services }\end{array}$ & $\begin{array}{c}0.00 \\
(0.00)\end{array}$ & $\begin{array}{c}-0.00^{* *} \\
(0.00)\end{array}$ & $\begin{array}{l}-0.00 \\
(0.00)\end{array}$ & $\begin{array}{c}-0.00 * * * \\
(0.00)\end{array}$ \\
\hline 61: Educational Services & $\begin{array}{c}-0.00 * \\
(0.00)\end{array}$ & $\begin{array}{c}0.00 \\
(0.00)\end{array}$ & $\begin{array}{c}0.00 \\
(0.00)\end{array}$ & $\begin{array}{c}0.00 \\
(0.00)\end{array}$ \\
\hline 62: Health Care, Social Assist. & $\begin{array}{c}0.00 \\
(0.00)\end{array}$ & $\begin{array}{c}0.00 \\
(0.00)\end{array}$ & $\begin{array}{c}0.00 \\
(0.00)\end{array}$ & $\begin{array}{l}0.00 * * \\
(0.00)\end{array}$ \\
\hline $\begin{array}{l}\text { 71: Arts, Entertainment, and } \\
\text { Recreation }\end{array}$ & $\begin{array}{l}-0.00 \\
(0.00)\end{array}$ & $\begin{array}{l}-0.00 \\
(0.00)\end{array}$ & $\begin{array}{l}-0.00 \\
(0.00)\end{array}$ & $\begin{array}{l}-0.00 \\
(0.00)\end{array}$ \\
\hline 72: Accommodation, Food Serv. & $\begin{array}{l}-0.00 \\
(0.00)\end{array}$ & $\begin{array}{l}-0.00 \\
(0.00)\end{array}$ & $\begin{array}{c}0.00 \\
(0.00)\end{array}$ & $\begin{array}{l}-0.00 \\
(0.00)\end{array}$ \\
\hline 81: Other Services & $\begin{array}{c}0.00 \\
(0.00)\end{array}$ & $\begin{array}{l}0.00^{*} \\
(0.00)\end{array}$ & $\begin{array}{c}0.00 \\
(0.00)\end{array}$ & $\begin{array}{c}0.00^{* *} \\
(0.00)\end{array}$ \\
\hline
\end{tabular}


Table A8. (cont'd)

\begin{tabular}{|c|c|c|c|c|}
\hline NAICS Sector & $\begin{array}{c}(1) \\
\text { Income } \\
\text { Growth Rate }\end{array}$ & $\begin{array}{l}\text { (2) } \\
\text { Employment } \\
\text { Growth Rate }\end{array}$ & $\begin{array}{c}(3) \\
\text { Poverty Rate } \\
\text { Growth }\end{array}$ & $\begin{array}{c}\text { (4) } \\
\text { Population } \\
\text { Growth Rate }\end{array}$ \\
\hline \% establishments under 11: Ag., & -0.89 & $1.48^{* *}$ & 0.22 & $1.12^{* *}$ \\
\hline Forestry, Fishing, Hunting & $(0.93)$ & $(0.63)$ & $(0.21)$ & $(0.47)$ \\
\hline 21: Mining, Quarrying, and & -0.38 & $1.81^{* * *}$ & 0.21 & $1.50^{* * *}$ \\
\hline Oil and Gas Extraction & $(0.94)$ & $(0.64)$ & $(0.21)$ & $(0.45)$ \\
\hline 22: Utilities & $\begin{array}{l}-0.62 \\
(1.46)\end{array}$ & $\begin{array}{l}-0.07 \\
(1.18)\end{array}$ & $\begin{array}{c}0.40 \\
(0.40)\end{array}$ & $\begin{array}{c}0.20 \\
(0.82)\end{array}$ \\
\hline 23: Construction & $\begin{array}{l}-0.95 \\
(0.93)\end{array}$ & $\begin{array}{c}2.12^{* * *} \\
(0.63)\end{array}$ & $\begin{array}{c}0.27 \\
(0.21)\end{array}$ & $\begin{array}{c}2.00^{* * *} \\
(0.46)\end{array}$ \\
\hline 31-33: Manufacturing & $\begin{array}{c}-1.61 * \\
(0.94)\end{array}$ & $\begin{array}{c}1.37 * * \\
(0.65)\end{array}$ & $\begin{array}{c}0.33 \\
(0.21)\end{array}$ & $\begin{array}{c}1.49 * * * \\
(0.47)\end{array}$ \\
\hline 42: Wholesale Trade & $\begin{array}{l}-0.60 \\
(0.97)\end{array}$ & $\begin{array}{c}1.77^{* * *} \\
(0.68)\end{array}$ & $\begin{array}{c}0.28 \\
(0.21)\end{array}$ & $\begin{array}{c}1.41^{* * *} \\
(0.48)\end{array}$ \\
\hline 44-45: Retail Trade & $\begin{array}{l}-0.84 \\
(0.92)\end{array}$ & $\begin{array}{c}1.58^{* *} \\
(0.65)\end{array}$ & $\begin{array}{c}0.26 \\
(0.21)\end{array}$ & $\begin{array}{c}1.40^{* * *} \\
(0.49)\end{array}$ \\
\hline $\begin{array}{l}\text { 48-49: Transportation and } \\
\text { Warehousing }\end{array}$ & $\begin{array}{l}-0.86 \\
(0.97)\end{array}$ & $\begin{array}{c}1.95^{* * *} \\
(0.67)\end{array}$ & $\begin{array}{c}0.26 \\
(0.21)\end{array}$ & $\begin{array}{c}1.70^{* * *} \\
(0.47)\end{array}$ \\
\hline 51: Information & $\begin{array}{c}0.28 \\
(1.26)\end{array}$ & $\begin{array}{l}1.87^{*} \\
(1.00)\end{array}$ & $\begin{array}{l}-0.00 \\
(0.27)\end{array}$ & $\begin{array}{l}1.10 \\
(0.75)\end{array}$ \\
\hline 52: Finance and Insurance & $\begin{array}{l}-0.99 \\
(0.96)\end{array}$ & $\begin{array}{c}1.65^{* * *} \\
(0.61)\end{array}$ & $\begin{array}{c}0.20 \\
(0.23)\end{array}$ & $\begin{array}{c}1.46^{* * *} \\
(0.50)\end{array}$ \\
\hline $\begin{array}{l}\text { 53: Real Estate, Rental \& } \\
\text { Leasing }\end{array}$ & $\begin{array}{l}-0.49 \\
(0.92)\end{array}$ & $\begin{array}{c}2.31^{* * *} \\
(0.64)\end{array}$ & $\begin{array}{c}0.25 \\
(0.21)\end{array}$ & $\begin{array}{c}2.11^{* * *} \\
(0.46)\end{array}$ \\
\hline $\begin{array}{l}\text { 54: Professional, Scientific, and } \\
\text { Technical Services }\end{array}$ & $\begin{array}{l}-0.50 \\
(0.94)\end{array}$ & $\begin{array}{c}1.61 * * * \\
(0.61)\end{array}$ & $\begin{array}{c}0.16 \\
(0.21)\end{array}$ & $\begin{array}{c}1.65^{* * *} \\
(0.45)\end{array}$ \\
\hline $\begin{array}{l}\text { Technical Services } \\
\text { 55: Management of Companies } \\
\text { and Enterprises }\end{array}$ & $\begin{array}{l}1.07 \\
(1.61)\end{array}$ & $\begin{array}{l}2.58 * * \\
(1.31)\end{array}$ & $\begin{array}{l}-0.19 \\
(0.43)\end{array}$ & $\begin{array}{c}0.11 \\
(1.07)\end{array}$ \\
\hline $\begin{array}{l}\text { 56: Administrative Support, } \\
\text { Waste Management and }\end{array}$ & $\begin{array}{l}-0.56 \\
(0.95)\end{array}$ & $\begin{array}{c}2.28^{* * *} \\
(0.66)\end{array}$ & $\begin{array}{c}0.29 \\
(0.21)\end{array}$ & $\begin{array}{c}2.06^{* * *} \\
(0.47)\end{array}$ \\
\hline Remediation Services & & & & \\
\hline 61: Educational Services & $\begin{array}{c}-0.79 \\
(1.04)\end{array}$ & $\begin{array}{c}1.00 \\
(0.88)\end{array}$ & $\begin{array}{c}0.31 \\
(0.26)\end{array}$ & $\begin{array}{c}0.99 \\
(0.65)\end{array}$ \\
\hline 62: Health Care, Social Assist. & $\begin{array}{l}-1.17 \\
(0.95)\end{array}$ & $\begin{array}{l}1.65^{* *} \\
(0.64)\end{array}$ & $\begin{array}{c}0.28 \\
(0.20)\end{array}$ & $\begin{array}{c}1.56^{* * *} \\
(0.45)\end{array}$ \\
\hline $\begin{array}{l}\text { 71: Arts, Entertainment, and } \\
\text { Recreation }\end{array}$ & $\begin{array}{l}-0.88 \\
(0.90)\end{array}$ & $\begin{array}{c}1.85^{* * *} \\
(0.65)\end{array}$ & $\begin{array}{c}0.21 \\
(0.21)\end{array}$ & $\begin{array}{c}1.59 * * * \\
(0.53)\end{array}$ \\
\hline 72: Accommodation, Food Serv. & $\begin{array}{c}-0.40 \\
(1.02)\end{array}$ & $\begin{array}{c}1.82 * * * * \\
(0.70)\end{array}$ & $\begin{array}{c}0.24 \\
(0.22)\end{array}$ & $\begin{array}{l}1.19 * * \\
(0.48)\end{array}$ \\
\hline 81: Other Services & $\begin{array}{c}-0.87 \\
(0.94)\end{array}$ & $\begin{array}{c}1.42^{* * *} \\
(0.63)\end{array}$ & $\begin{array}{c}0.23 \\
(0.21)\end{array}$ & $\begin{array}{c}1.34 * * * \\
(0.48)\end{array}$ \\
\hline
\end{tabular}


Table A8. (cont'd)

\begin{tabular}{|c|c|c|c|c|}
\hline State Variables & $\begin{array}{c}(1) \\
\text { Income } \\
\text { Growth Rate }\end{array}$ & $\begin{array}{c}\text { (2) } \\
\text { Employment } \\
\text { Growth Rate }\end{array}$ & $\begin{array}{c}(3) \\
\text { Poverty Rate } \\
\text { Growth }\end{array}$ & $\begin{array}{c}\text { (4) } \\
\text { Population } \\
\text { Growth Rate }\end{array}$ \\
\hline Arizona & $\begin{array}{c}-0.05^{* *} \\
(0.02)\end{array}$ & $\begin{array}{l}0.08^{*} \\
(0.04)\end{array}$ & $\begin{array}{c}0.01 \\
(0.01)\end{array}$ & $\begin{array}{c}0.07 \\
(0.05)\end{array}$ \\
\hline Arkansas & $\begin{array}{c}-0.04 * * * \\
(0.01)\end{array}$ & $\begin{array}{c}-0.03^{*} \\
(0.01)\end{array}$ & $\begin{array}{c}0.02^{* * *} \\
(0.00)\end{array}$ & $\begin{array}{l}-0.01 \\
(0.01)\end{array}$ \\
\hline California & $\begin{array}{l}-0.00 \\
(0.02)\end{array}$ & $\begin{array}{c}0.03 \\
(0.02)\end{array}$ & $\begin{array}{l}-0.00 \\
(0.01)\end{array}$ & $\begin{array}{c}0.03 \\
(0.02)\end{array}$ \\
\hline Colorado & $\begin{array}{l}-0.03^{*} \\
(0.02)\end{array}$ & $\begin{array}{c}-0.03 \\
(0.02)\end{array}$ & $\begin{array}{c}0.01^{* *} \\
(0.01)\end{array}$ & $\begin{array}{c}-0.03^{*} \\
(0.02)\end{array}$ \\
\hline Connecticut & $\begin{array}{c}0.09 * * * \\
(0.02)\end{array}$ & $\begin{array}{c}0.03 \\
(0.02)\end{array}$ & $\begin{array}{c}-0.01 * * \\
(0.01)\end{array}$ & $\begin{array}{c}-0.02 \\
(0.02)\end{array}$ \\
\hline Delaware & $\begin{array}{l}-0.00 \\
(0.04)\end{array}$ & $\begin{array}{c}0.07^{* *} \\
(0.03)\end{array}$ & $\begin{array}{c}0.00 \\
(0.01)\end{array}$ & $\begin{array}{c}0.14^{* * *} \\
(0.02)\end{array}$ \\
\hline District of Columbia & $\begin{array}{c}0.09 \\
(0.11)\end{array}$ & $\begin{array}{c}-0.02 \\
(0.10)\end{array}$ & $\begin{array}{l}-0.03 \\
(0.02)\end{array}$ & $\begin{array}{c}-0.09 \\
(0.09)\end{array}$ \\
\hline Florida & $\begin{array}{c}-0.05 * * * \\
(0.02)\end{array}$ & $\begin{array}{c}0.08^{* * *} \\
(0.02)\end{array}$ & $\begin{array}{l}0.01 * \\
(0.01)\end{array}$ & $\begin{array}{c}0.11^{* * *} \\
(0.02)\end{array}$ \\
\hline Geogia & $\begin{array}{c}-0.06^{* * * *} \\
(0.01)\end{array}$ & $\begin{array}{c}0.01 \\
(0.01)\end{array}$ & $\begin{array}{c}0.01^{* * *} \\
(0.00)\end{array}$ & $\begin{array}{c}0.05^{* * *} \\
(0.01)\end{array}$ \\
\hline Idaho & $\begin{array}{c}-0.10^{* * * *} \\
(0.02)\end{array}$ & $\begin{array}{c}0.01 \\
(0.02)\end{array}$ & $\begin{array}{c}0.02^{* * *} \\
(0.01)\end{array}$ & $\begin{array}{c}0.01 \\
(0.02)\end{array}$ \\
\hline Illinois & $\begin{array}{c}-0.03^{* *} \\
(0.01)\end{array}$ & $\begin{array}{c}-0.02 \\
(0.02)\end{array}$ & $\begin{array}{c}0.02^{* * * *} \\
(0.00)\end{array}$ & $\begin{array}{c}-0.02 \\
(0.01)\end{array}$ \\
\hline Indiana & $\begin{array}{c}-0.06 * * * \\
(0.01)\end{array}$ & $\begin{array}{c}-0.07 * * * \\
(0.02)\end{array}$ & $\begin{array}{c}0.02^{* * * *} \\
(0.00)\end{array}$ & $\begin{array}{c}-0.05 * * * \\
(0.01)\end{array}$ \\
\hline Iowa & $\begin{array}{l}-0.02 \\
(0.02)\end{array}$ & $\begin{array}{c}-0.02 \\
(0.02)\end{array}$ & $\begin{array}{c}0.01^{* *} \\
(0.01)\end{array}$ & $\begin{array}{c}-0.04 * * * \\
(0.01)\end{array}$ \\
\hline Kansas & $\begin{array}{c}-0.06^{* * * *} \\
(0.02)\end{array}$ & $\begin{array}{c}-0.03^{* * *} \\
(0.02)\end{array}$ & $\begin{array}{c}0.01^{* *} \\
(0.01)\end{array}$ & $\begin{array}{c}-0.05^{* * * *} \\
(0.01)\end{array}$ \\
\hline Kentucky & $\begin{array}{l}-0.02 \\
(0.01)\end{array}$ & $\begin{array}{c}-0.03^{* * *} \\
(0.01)\end{array}$ & $\begin{array}{c}0.02^{* * *} \\
(0.00)\end{array}$ & $\begin{array}{c}-0.01 \\
(0.01)\end{array}$ \\
\hline Louisiana & $\begin{array}{c}0.06^{* * * *} \\
(0.02)\end{array}$ & $\begin{array}{c}0.02 \\
(0.02)\end{array}$ & $\begin{array}{c}-0.01 * * \\
(0.01)\end{array}$ & $\begin{array}{l}-0.01 \\
(0.02)\end{array}$ \\
\hline Maine & $\begin{array}{l}-0.01 \\
(0.02)\end{array}$ & $\begin{array}{c}0.01 \\
(0.02)\end{array}$ & $\begin{array}{c}0.01 \\
(0.01)\end{array}$ & $\begin{array}{c}0.01 \\
(0.02)\end{array}$ \\
\hline Maryland & $\begin{array}{c}0.08 * * * \\
(0.02)\end{array}$ & $\begin{array}{c}0.04^{* *} \\
(0.02)\end{array}$ & $\begin{array}{c}-0.02 * * * \\
(0.01)\end{array}$ & $\begin{array}{c}0.01 \\
(0.02)\end{array}$ \\
\hline
\end{tabular}


Table A8. (cont'd)

\begin{tabular}{|c|c|c|c|c|}
\hline State Variables & $\begin{array}{c}(1) \\
\text { Income } \\
\text { Growth Rate }\end{array}$ & \begin{tabular}{l}
\multicolumn{1}{c}{$(2)$} \\
Employment \\
Growth Rate
\end{tabular} & $\begin{array}{c}(3) \\
\text { Poverty Rate } \\
\text { Growth }\end{array}$ & $\begin{array}{c}\text { (4) } \\
\text { Population } \\
\text { Growth Rate }\end{array}$ \\
\hline Massachusetts & $\begin{array}{l}0.06^{*} \\
(0.03)\end{array}$ & $\begin{array}{c}-0.01 \\
(0.02)\end{array}$ & $\begin{array}{c}-0.02 * * * \\
(0.01)\end{array}$ & $\begin{array}{l}-0.04^{*} \\
(0.02)\end{array}$ \\
\hline Michigan & $\begin{array}{c}-0.10 * * * \\
(0.01)\end{array}$ & $\begin{array}{c}-0.11 * * * \\
(0.02)\end{array}$ & $\begin{array}{c}0.03^{* * * *} \\
(0.01)\end{array}$ & $\begin{array}{c}-0.08 * * * \\
(0.01)\end{array}$ \\
\hline Minnesota & $\begin{array}{l}-0.01 \\
(0.02)\end{array}$ & $\begin{array}{c}0.01 \\
(0.02)\end{array}$ & $\begin{array}{c}0.01^{* * * *} \\
(0.01)\end{array}$ & $\begin{array}{c}-0.03^{* *} \\
(0.01)\end{array}$ \\
\hline Mississippi & $\begin{array}{c}-0.03^{*} \\
(0.01)\end{array}$ & $\begin{array}{c}-0.03^{*} \\
(0.02)\end{array}$ & $\begin{array}{c}0.01^{* *} \\
(0.01)\end{array}$ & $\begin{array}{c}-0.01 \\
(0.01)\end{array}$ \\
\hline Missouri & $\begin{array}{c}-0.05^{* * * *} \\
(0.01)\end{array}$ & $\begin{array}{c}0.00 \\
(0.01)\end{array}$ & $\begin{array}{c}0.01^{* *} \\
(0.00)\end{array}$ & $\begin{array}{c}0.01 \\
(0.01)\end{array}$ \\
\hline Montana & $\begin{array}{l}-0.03^{*} \\
(0.02)\end{array}$ & $\begin{array}{c}0.02 \\
(0.02)\end{array}$ & $\begin{array}{c}0.01 \\
(0.01)\end{array}$ & $\begin{array}{c}0.02 \\
(0.02)\end{array}$ \\
\hline Nebraska & $\begin{array}{c}-0.05 * * * \\
(0.02)\end{array}$ & $\begin{array}{l}-0.01 \\
(0.02)\end{array}$ & $\begin{array}{c}0.01^{* *} \\
(0.01)\end{array}$ & $\begin{array}{c}-0.03^{* * *} \\
(0.01)\end{array}$ \\
\hline Nevada & $\begin{array}{l}-0.03 \\
(0.04)\end{array}$ & $\begin{array}{c}0.04 \\
(0.03)\end{array}$ & $\begin{array}{l}0.02^{*} \\
(0.01)\end{array}$ & $\begin{array}{c}0.06 \\
(0.04)\end{array}$ \\
\hline New Hampshire & $\begin{array}{c}0.00 \\
(0.02)\end{array}$ & $\begin{array}{c}-0.01 \\
(0.02)\end{array}$ & $\begin{array}{l}-0.00 \\
(0.01)\end{array}$ & $\begin{array}{c}-0.04 * * \\
(0.02)\end{array}$ \\
\hline New Jersey & $\begin{array}{c}0.05^{* * *} \\
(0.02)\end{array}$ & $\begin{array}{c}-0.04^{*} \\
(0.02)\end{array}$ & $\begin{array}{c}-0.01 \\
(0.01)\end{array}$ & $\begin{array}{c}-0.07 * * * \\
(0.02)\end{array}$ \\
\hline New Mexico & $\begin{array}{l}-0.04 \\
(0.03)\end{array}$ & $\begin{array}{c}0.02 \\
(0.03)\end{array}$ & $\begin{array}{c}-0.01 \\
(0.01)\end{array}$ & $\begin{array}{c}0.02 \\
(0.02)\end{array}$ \\
\hline New York & $\begin{array}{l}-0.01 \\
(0.02)\end{array}$ & $\begin{array}{c}-0.00 \\
(0.02)\end{array}$ & $\begin{array}{c}0.00 \\
(0.01)\end{array}$ & $\begin{array}{c}-0.02 \\
(0.01)\end{array}$ \\
\hline North Carolina & $\begin{array}{c}-0.03^{* * *} \\
(0.01)\end{array}$ & $\begin{array}{c}-0.00 \\
(0.01)\end{array}$ & $\begin{array}{c}0.02^{* * *} \\
(0.00)\end{array}$ & $\begin{array}{c}0.05^{* * *} \\
(0.01)\end{array}$ \\
\hline North Dakota & $\begin{array}{c}0.06^{* * *} \\
(0.02)\end{array}$ & $\begin{array}{c}0.02 \\
(0.02)\end{array}$ & $\begin{array}{c}0.00 \\
(0.01)\end{array}$ & $\begin{array}{c}-0.04 * * \\
(0.02)\end{array}$ \\
\hline Ohio & $\begin{array}{c}-0.06 * * * \\
(0.01)\end{array}$ & $\begin{array}{c}-0.06 * * * \\
(0.02)\end{array}$ & $\begin{array}{c}0.02 * * * \\
(0.01)\end{array}$ & $\begin{array}{c}-0.05^{* * * *} \\
(0.01)\end{array}$ \\
\hline Oklahoma & $\begin{array}{c}-0.04 * * \\
(0.02)\end{array}$ & $\begin{array}{c}0.00 \\
(0.02)\end{array}$ & $\begin{array}{c}0.01 \\
(0.01)\end{array}$ & $\begin{array}{c}0.01 \\
(0.01)\end{array}$ \\
\hline Oregon & $\begin{array}{c}-0.05^{* * * *} \\
(0.02)\end{array}$ & $\begin{array}{c}0.01 \\
(0.02)\end{array}$ & $\begin{array}{c}0.02^{* * *} \\
(0.01)\end{array}$ & $\begin{array}{c}0.02 \\
(0.02)\end{array}$ \\
\hline Pennsylvania & $\begin{array}{l}-0.02 \\
(0.02)\end{array}$ & $\begin{array}{c}0.00 \\
(0.02)\end{array}$ & $\begin{array}{l}-0.00 \\
(0.01)\end{array}$ & $\begin{array}{l}-0.01 \\
(0.01)\end{array}$ \\
\hline Rhode Island & $\begin{array}{c}0.05^{* * *} \\
(0.02)\end{array}$ & $\begin{array}{c}-0.05^{*} \\
(0.02)\end{array}$ & $\begin{array}{c}-0.02 * * * \\
(0.01)\end{array}$ & $\begin{array}{c}-0.10^{* * *} \\
(0.02)\end{array}$ \\
\hline South Carolina & $\begin{array}{c}-0.04 * * * \\
(0.01)\end{array}$ & $\begin{array}{l}-0.01 \\
(0.02)\end{array}$ & $\begin{array}{c}0.02^{* * *} \\
(0.01)\end{array}$ & $\begin{array}{c}0.04 * * * \\
(0.01)\end{array}$ \\
\hline
\end{tabular}


Table A8. (cont'd)

\begin{tabular}{|c|c|c|c|c|}
\hline State Variables & $\begin{array}{c}\text { (1) } \\
\text { Income } \\
\text { Growth Rate }\end{array}$ & $\begin{array}{l}\text { (2) } \\
\text { Employment } \\
\text { Growth Rate }\end{array}$ & $\begin{array}{c}\text { (3) } \\
\text { Poverty Rate } \\
\text { Growth }\end{array}$ & $\begin{array}{c}\text { (4) } \\
\text { Population } \\
\text { Growth Rate }\end{array}$ \\
\hline South Dakota & $\begin{array}{c}0.01 \\
(0.02)\end{array}$ & $\begin{array}{c}0.01 \\
(0.02)\end{array}$ & $\begin{array}{c}0.00 \\
(0.01)\end{array}$ & $\begin{array}{l}-0.02 \\
(0.02)\end{array}$ \\
\hline Tennessee & $\begin{array}{c}-0.03^{* *} \\
(0.01)\end{array}$ & $\begin{array}{c}-0.04 * * * \\
(0.01)\end{array}$ & $\begin{array}{c}0.02 * * * \\
(0.00)\end{array}$ & $\begin{array}{c}0.00 \\
(0.01)\end{array}$ \\
\hline Texas & $\begin{array}{c}-0.03^{* *} \\
(0.01)\end{array}$ & $\begin{array}{l}0.03^{* *} \\
(0.01)\end{array}$ & $\begin{array}{c}0.01 \\
(0.00)\end{array}$ & $\begin{array}{l}0.02 * \\
(0.01)\end{array}$ \\
\hline Utah & $\begin{array}{c}-0.07^{* *} \\
(0.03)\end{array}$ & $\begin{array}{l}-0.01 \\
(0.03)\end{array}$ & $\begin{array}{l}-0.01 \\
(0.01)\end{array}$ & $\begin{array}{c}0.01 \\
(0.02)\end{array}$ \\
\hline Vermont & $\begin{array}{l}-0.00 \\
(0.02)\end{array}$ & $\begin{array}{l}-0.01 \\
(0.02)\end{array}$ & $\begin{array}{l}-0.00 \\
(0.01)\end{array}$ & $\begin{array}{c}-0.05 * * * \\
(0.02)\end{array}$ \\
\hline Virginia & $\begin{array}{l}0.03^{* *} \\
(0.01)\end{array}$ & $\begin{array}{c}0.01 \\
(0.02)\end{array}$ & $\begin{array}{l}-0.01^{*} \\
(0.00)\end{array}$ & $\begin{array}{c}0.01 \\
(0.01)\end{array}$ \\
\hline Washington & $\begin{array}{c}-0.04^{* *} \\
(0.02)\end{array}$ & $\begin{array}{l}0.04 * \\
(0.02)\end{array}$ & $\begin{array}{c}0.02^{* * *} \\
(0.01)\end{array}$ & $\begin{array}{c}0.06^{* * * *} \\
(0.02)\end{array}$ \\
\hline West Virginia & $\begin{array}{c}-0.04^{* *} \\
(0.02)\end{array}$ & $\begin{array}{c}0.03 \\
(0.02)\end{array}$ & $\begin{array}{c}0.00 \\
(0.01)\end{array}$ & $\begin{array}{c}0.01 \\
(0.01)\end{array}$ \\
\hline Wisconsin & $\begin{array}{c}-0.04^{* *} \\
(0.02)\end{array}$ & $\begin{array}{l}-0.01 \\
(0.02)\end{array}$ & $\begin{array}{c}0.02^{* * *} \\
(0.01)\end{array}$ & $\begin{array}{l}-0.02 \\
(0.01)\end{array}$ \\
\hline Wyoming & $\begin{array}{l}0.03 * \\
(0.02)\end{array}$ & $\begin{array}{c}0.08^{* * * *} \\
(0.03)\end{array}$ & $\begin{array}{c}-0.01^{* *} \\
(0.01)\end{array}$ & $\begin{array}{l}0.06^{* *} \\
(0.02)\end{array}$ \\
\hline Constant & $\begin{array}{l}-0.08 \\
(0.94)\end{array}$ & $\begin{array}{c}-1.63 * * \\
(0.65)\end{array}$ & $\begin{array}{c}0.09 \\
(0.21)\end{array}$ & $\begin{array}{c}-1.24^{* *} \\
(0.49)\end{array}$ \\
\hline $\begin{array}{l}\text { Observations } \\
R^{2}\end{array}$ & $\begin{array}{c}\sim 3,100 \\
0.48\end{array}$ & $\begin{array}{c}\sim 3,100 \\
0.49\end{array}$ & $\begin{array}{c}\sim 3,100 \\
0.43\end{array}$ & $\begin{array}{c}\sim 3,100 \\
0.64\end{array}$ \\
\hline
\end{tabular}

Robust standard errors in parentheses

${ }^{* * *} \mathrm{p}<0.01,{ }^{* *} \mathrm{p}<0.05,{ }^{*} \mathrm{p}<0.1$ 
Table A9. SDM Regression of Economic Performance on 2002 Industry LOB Employment Share

\begin{tabular}{|c|c|c|c|c|}
\hline County Variables & $\begin{array}{c}\text { (1) } \\
\text { Income } \\
\text { Growth Rate }\end{array}$ & $\begin{array}{l}\text { (2) } \\
\text { Employment } \\
\text { Growth Rate }\end{array}$ & $\begin{array}{c}\text { (3) } \\
\text { Poverty Rate } \\
\text { Growth }\end{array}$ & $\begin{array}{c}\text { (4) } \\
\text { Population } \\
\text { Growth Rate }\end{array}$ \\
\hline Per capita income & $\begin{array}{c}-0.00 * * * \\
(0.00)\end{array}$ & $\begin{array}{l}-0.00 * \\
(0.00)\end{array}$ & $\begin{array}{c}-0.00 * * * \\
(0.00)\end{array}$ & $\begin{array}{l}-0.00 \\
(0.00)\end{array}$ \\
\hline Employment & $\begin{array}{c}-0.00 * * * \\
(0.00)\end{array}$ & $\begin{array}{c}-0.00 * * * \\
(0.00)\end{array}$ & $\begin{array}{c}0.00 * * * \\
(0.00)\end{array}$ & $\begin{array}{l}-0.00 \\
(0.00)\end{array}$ \\
\hline Poverty rate & $\begin{array}{c}0.31^{* * *} \\
(0.08)\end{array}$ & $\begin{array}{l}-0.07 \\
(0.09)\end{array}$ & $\begin{array}{c}-0.49 * * * \\
(0.03)\end{array}$ & $\begin{array}{l}-0.12^{*} \\
(0.07)\end{array}$ \\
\hline Population & $\begin{array}{c}0.00 \\
(0.00)\end{array}$ & $\begin{array}{l}-0.00^{*} \\
(0.00)\end{array}$ & $\begin{array}{c}-0.00^{* *} \\
(0.00)\end{array}$ & $\begin{array}{c}-0.00 * * * \\
(0.00)\end{array}$ \\
\hline Population squared & $\begin{array}{l}-0.00 * \\
(0.00)\end{array}$ & $\begin{array}{l}-0.00 \\
(0.00)\end{array}$ & $\begin{array}{c}0.00 * * * \\
(0.00)\end{array}$ & $\begin{array}{c}0.00 \\
(0.00)\end{array}$ \\
\hline Population density & $\begin{array}{c}-0.00 * * \\
(0.00)\end{array}$ & $\begin{array}{l}-0.00 \\
(0.00)\end{array}$ & $\begin{array}{c}0.00 * * \\
(0.00)\end{array}$ & $\begin{array}{l}-0.00 \\
(0.00)\end{array}$ \\
\hline Average household size & $\begin{array}{c}0.07 * * * \\
(0.02)\end{array}$ & $\begin{array}{c}0.11^{* * *} \\
(0.02)\end{array}$ & $\begin{array}{c}0.01 * * \\
(0.01)\end{array}$ & $\begin{array}{c}0.05^{* * * *} \\
(0.02)\end{array}$ \\
\hline \% headed by single female & $\begin{array}{c}-0.69 * * * \\
(0.09)\end{array}$ & $\begin{array}{c}-0.39 * * * \\
(0.10)\end{array}$ & $\begin{array}{c}0.34^{* * *} \\
(0.03)\end{array}$ & $\begin{array}{c}-0.50^{* * *} \\
(0.08)\end{array}$ \\
\hline Median age & $\begin{array}{c}0.03 * * * \\
(0.01)\end{array}$ & $\begin{array}{l}-0.01 \\
(0.01)\end{array}$ & $\begin{array}{c}-0.01 * * * \\
(0.00)\end{array}$ & $\begin{array}{l}-0.01 \\
(0.01)\end{array}$ \\
\hline Median age squared & $\begin{array}{c}-0.00 * * * \\
(0.00)\end{array}$ & $\begin{array}{c}0.00 \\
(0.00)\end{array}$ & $\begin{array}{c}0.00^{* * *} \\
(0.00)\end{array}$ & $\begin{array}{c}0.00 \\
(0.00)\end{array}$ \\
\hline Female population & $\begin{array}{l}-0.00 \\
(0.00)\end{array}$ & $\begin{array}{l}0.00 * * \\
(0.00)\end{array}$ & $\begin{array}{c}0.00 \\
(0.00)\end{array}$ & $\begin{array}{c}0.00 * * * \\
(0.00)\end{array}$ \\
\hline Female population squared & $\begin{array}{l}0.00 * \\
(0.00)\end{array}$ & $\begin{array}{c}0.00 \\
(0.00)\end{array}$ & $\begin{array}{c}-0.00 * * * \\
(0.00)\end{array}$ & $\begin{array}{l}-0.00 \\
(0.00)\end{array}$ \\
\hline Asian population & $\begin{array}{l}-0.00 \\
(0.00)\end{array}$ & $\begin{array}{c}0.00 \\
(0.00)\end{array}$ & $\begin{array}{l}-0.00 \\
(0.00)\end{array}$ & $\begin{array}{c}0.00 \\
(0.00)\end{array}$ \\
\hline Asian population squared & $\begin{array}{c}0.00 \\
(0.00)\end{array}$ & $\begin{array}{c}0.00 \\
(0.00)\end{array}$ & $\begin{array}{c}0.00 \\
(0.00)\end{array}$ & $\begin{array}{c}0.00 \\
(0.00)\end{array}$ \\
\hline Black population & $\begin{array}{l}-0.00^{*} \\
(0.00)\end{array}$ & $\begin{array}{c}-0.00^{* *} \\
(0.00)\end{array}$ & $\begin{array}{l}-0.00 \\
(0.00)\end{array}$ & $\begin{array}{c}-0.00 * * * \\
(0.00)\end{array}$ \\
\hline Black population squared & $\begin{array}{l}-0.00 \\
(0.00)\end{array}$ & $\begin{array}{c}0.00 \\
(0.00)\end{array}$ & $\begin{array}{c}0.00^{* * *} \\
(0.00)\end{array}$ & $\begin{array}{c}0.00 * * * \\
(0.00)\end{array}$ \\
\hline Hispanic population & $\begin{array}{c}-0.00 * * * \\
(0.00)\end{array}$ & $\begin{array}{c}0.00 \\
(0.00)\end{array}$ & $\begin{array}{c}0.00 * * * \\
(0.00)\end{array}$ & $\begin{array}{l}0.00 * \\
(0.00)\end{array}$ \\
\hline Hispanic population squared & $\begin{array}{l}-0.00 \\
(0.00)\end{array}$ & $\begin{array}{l}-0.00 \\
(0.00)\end{array}$ & $\begin{array}{l}-0.00 \\
(0.00)\end{array}$ & $\begin{array}{c}0.00 \\
(0.00)\end{array}$ \\
\hline
\end{tabular}


Table A9. (cont'd)

\begin{tabular}{lcccc}
\hline County Variables & $\begin{array}{c}(1) \\
\text { Income } \\
\text { Growth Rate }\end{array}$ & $\begin{array}{c}(2) \\
\text { Employment } \\
\text { Growth Rate }\end{array}$ & $\begin{array}{c}(3) \\
\text { Poverty Rate } \\
\text { Growth }\end{array}$ & $\begin{array}{c}(4) \\
\text { Population } \\
\text { Growth Rate }\end{array}$ \\
\hline \% owner's education: high school & -0.04 & $0.06^{*}$ & 0.01 & $0.04^{*}$ \\
& $(0.03)$ & $(0.03)$ & $(0.01)$ & $(0.02)$ \\
Some college & $-0.08^{* *}$ & 0.01 & -0.00 & $0.05^{* *}$ \\
& $(0.04)$ & $(0.04)$ & $(0.01)$ & $(0.03)$ \\
Trade school degree & 0.04 & 0.04 & -0.01 & -0.04 \\
& $(0.04)$ & $(0.04)$ & $(0.01)$ & $(0.03)$ \\
Associates degree & -0.04 & 0.08 & -0.00 & 0.04 \\
Bachelor's degree & $(0.06)$ & $(0.06)$ & $(0.02)$ & $(0.05)$ \\
& $-0.07^{*}$ & 0.06 & -0.00 & 0.02 \\
Graduate school degree & $(0.04)$ & $(0.04)$ & $(0.01)$ & $(0.04)$ \\
Taxes per capita & 0.05 & 0.06 & $-0.04^{* *}$ & 0.02 \\
& $(0.05)$ & $(0.05)$ & $(0.02)$ & $(0.04)$ \\
Education spending & -0.00 & 0.00 & 0.00 & $-0.00^{*}$ \\
& $(0.00)$ & $(0.00)$ & $(0.00)$ & $(0.00)$ \\
Highway spending & $-0.00^{*}$ & -0.00 & -0.00 & -0.00 \\
& $(0.00)$ & $(0.00)$ & $(0.00)$ & $(0.00)$ \\
Labor force participation rate & $0.00^{*}$ & 0.00 & -0.00 & 0.00 \\
& $(0.00)$ & $(0.00)$ & $(0.00)$ & $(0.00)$ \\
Build permits & $0.28^{* * *}$ & -0.10 & $-0.04^{* * *}$ & 0.01 \\
& $(0.04)$ & $(0.07)$ & $(0.01)$ & $(0.05)$ \\
& -0.00 & $0.00^{* * *}$ & $-0.00^{*}$ & $0.00^{* * *}$ \\
& $(0.00)$ & $(0.00)$ & $(0.00)$ & $(0.00)$ \\
\hline
\end{tabular}


Table A9. (cont'd)

\begin{tabular}{|c|c|c|c|c|}
\hline NAICS Sector & $\begin{array}{c}(1) \\
\text { Income } \\
\text { Growth Rate }\end{array}$ & $\begin{array}{c}\text { (2) } \\
\text { Employment } \\
\text { Growth Rate }\end{array}$ & $\begin{array}{l}\text { (3) } \\
\text { Poverty Rate } \\
\text { Growth }\end{array}$ & $\begin{array}{c}\text { (4) } \\
\text { Population } \\
\text { Growth Rate }\end{array}$ \\
\hline $\begin{array}{l}\text { Employment under 11: Ag., } \\
\text { Forestry Fishing Hunting }\end{array}$ & $\begin{array}{r}-0.00 \\
(0.00)\end{array}$ & $\begin{array}{c}0.00 \\
(0.00)\end{array}$ & $\begin{array}{c}0.00 \\
(0.00)\end{array}$ & $\begin{array}{r}-0.00 \\
(0.00)\end{array}$ \\
\hline 21: Mining, Quarrying, and & 0.00 & $0.00^{* *}$ & -0.00 & 0.00 \\
\hline Oil and Gas Extraction & $(0.00)$ & $(0.00)$ & $(0.00)$ & $(0.00)$ \\
\hline 22: Utilities & $\begin{array}{c}0.00^{* *} \\
(0.00)\end{array}$ & $\begin{array}{c}0.00^{* * *} \\
(0.00)\end{array}$ & $\begin{array}{c}-0.00 * * \\
(0.00)\end{array}$ & $\begin{array}{c}0.00 \\
(0.00)\end{array}$ \\
\hline 23: Construction & $\begin{array}{l}-0.00 \\
(0.00)\end{array}$ & $\begin{array}{c}-0.00 * * * \\
(0.00)\end{array}$ & $\begin{array}{c}0.00^{* * *} \\
(0.00)\end{array}$ & $\begin{array}{c}-0.00 * * * \\
(0.00)\end{array}$ \\
\hline 31-33: Manufacturing & $\begin{array}{c}-0.00 * * * \\
(0.00)\end{array}$ & $\begin{array}{l}-0.00 \\
(0.00)\end{array}$ & $\begin{array}{c}0.00^{* *} \\
(0.00)\end{array}$ & $\begin{array}{c}0.00 \\
(0.00)\end{array}$ \\
\hline 42: Wholesale Trade & $\begin{array}{l}-0.00 \\
(0.00)\end{array}$ & $\begin{array}{c}0.00 \\
(0.00)\end{array}$ & $\begin{array}{c}-0.00 * * * \\
(0.00)\end{array}$ & $\begin{array}{c}0.00 \\
(0.00)\end{array}$ \\
\hline 44-45: Retail Trade & $\begin{array}{l}-0.00^{*} \\
(0.00)\end{array}$ & $\begin{array}{l}-0.00 \\
(0.00)\end{array}$ & $\begin{array}{c}0.00^{* *} \\
(0.00)\end{array}$ & $\begin{array}{l}-0.00^{*} \\
(0.00)\end{array}$ \\
\hline $\begin{array}{l}\text { 48-49: Transportation and } \\
\text { Warehousing }\end{array}$ & $\begin{array}{c}0.00 \\
(0.00)\end{array}$ & $\begin{array}{c}0.00 \\
(0.00)\end{array}$ & $\begin{array}{c}-0.00 \\
(0.00)\end{array}$ & $\begin{array}{c}0.00 \\
(0.00)\end{array}$ \\
\hline 51: Information & $\begin{array}{c}0.00 \\
(0.00)\end{array}$ & $\begin{array}{c}-0.00^{* * * *} \\
(0.00)\end{array}$ & $\begin{array}{c}0.00 \\
(0.00)\end{array}$ & $\begin{array}{c}-0.00 * * * \\
(0.00)\end{array}$ \\
\hline 52: Finance and Insurance & $\begin{array}{c}0.00 \\
(0.00)\end{array}$ & $\begin{array}{c}0.00 \\
(0.00)\end{array}$ & $\begin{array}{c}0.00 \\
(0.00)\end{array}$ & $\begin{array}{l}0.00^{*} \\
(0.00)\end{array}$ \\
\hline $\begin{array}{l}\text { 53: Real Estate, Rental \& } \\
\text { Leasing }\end{array}$ & $\begin{array}{c}0.00^{* * *} \\
(0.00)\end{array}$ & $\begin{array}{l}0.00^{*} \\
(0.00)\end{array}$ & $\begin{array}{l}-0.00 \\
(0.00)\end{array}$ & $\begin{array}{c}0.00 \\
(0.00)\end{array}$ \\
\hline $\begin{array}{l}\text { 54: Professional, Scientific, and } \\
\text { Technical Services }\end{array}$ & $\begin{array}{l}0.00 * * \\
(0.00)\end{array}$ & $0.00 * * *$ & $\begin{array}{l}-0.00^{*} \\
(0.00)\end{array}$ & $\begin{array}{l}0.00 * * \\
(0.00)\end{array}$ \\
\hline $\begin{array}{l}\text { Technical Services } \\
\text { 55: Management of Companies } \\
\text { and Enterprises }\end{array}$ & $\begin{array}{l}(0.00) \\
0.00^{* *} \\
(0.00)\end{array}$ & $\begin{array}{c}(0.00) \\
0.00 \\
(0.00)\end{array}$ & $\begin{array}{l}(0.00) \\
-0.00 \\
(0.00)\end{array}$ & $\begin{array}{c}(0.00) \\
0.00 \\
(0.00)\end{array}$ \\
\hline $\begin{array}{l}\text { 56: Administrative Support, } \\
\text { Waste Management and } \\
\text { Remediation Services }\end{array}$ & $\begin{array}{l}-0.00 \\
(0.00)\end{array}$ & $\begin{array}{c}-0.00 * * * \\
(0.00)\end{array}$ & $\begin{array}{c}0.00 \\
(0.00)\end{array}$ & $\begin{array}{c}-0.00 * * * \\
(0.00)\end{array}$ \\
\hline 61: Educational Services & $\begin{array}{c}-0.00 * \\
(0.00)\end{array}$ & $\begin{array}{c}0.00 \\
(0.00)\end{array}$ & $\begin{array}{c}0.00 \\
(0.00)\end{array}$ & $\begin{array}{c}0.00 \\
(0.00)\end{array}$ \\
\hline 62: Health Care, Social Assist. & $\begin{array}{c}0.00 \\
(0.00)\end{array}$ & $\begin{array}{c}0.00 \\
(0.00)\end{array}$ & $\begin{array}{c}0.00 \\
(0.00)\end{array}$ & $\begin{array}{l}0.00 * * \\
(0.00)\end{array}$ \\
\hline $\begin{array}{l}\text { 71: Arts, Entertainment, and } \\
\text { Recreation }\end{array}$ & $\begin{array}{l}-0.00 \\
(0.00)\end{array}$ & $\begin{array}{c}-0.00 * * \\
(0.00)\end{array}$ & $\begin{array}{c}-0.00 \\
(0.00)\end{array}$ & $\begin{array}{c}-0.00 * * \\
(0.00)\end{array}$ \\
\hline 72: Accommodation, Food Serv. & $\begin{array}{c}-0.00 \\
(0.00)\end{array}$ & $\begin{array}{c}-0.00 \\
(0.00)\end{array}$ & $\begin{array}{c}-0.00 \\
(0.00)\end{array}$ & $\begin{array}{c}-0.00 \\
(0.00)\end{array}$ \\
\hline 81: Other Services & $\begin{array}{c}0.00 \\
(0.00)\end{array}$ & $\begin{array}{c}0.00^{* * * *} \\
(0.00)\end{array}$ & $\begin{array}{c}-0.00 \\
(0.00)\end{array}$ & $\begin{array}{c}0.00^{* * *} \\
(0.00)\end{array}$ \\
\hline
\end{tabular}


Table A9. (cont'd)

\begin{tabular}{|c|c|c|c|c|}
\hline NAICS Sector & $\begin{array}{c}(1) \\
\text { Income } \\
\text { Growth Rate }\end{array}$ & $\begin{array}{c}\text { (2) } \\
\text { Employment } \\
\text { Growth Rate }\end{array}$ & $\begin{array}{l}\text { (3) } \\
\text { Poverty Rate } \\
\text { Growth }\end{array}$ & $\begin{array}{c}\text { (4) } \\
\text { Population } \\
\text { Growth Rate }\end{array}$ \\
\hline $\begin{array}{l}\% \text { establishments under 11: Ag., } \\
\text { Forestry Fishing Hunting }\end{array}$ & $\begin{array}{r}-0.99 \\
(0.78)\end{array}$ & $\begin{array}{c}0.97 \\
(0.62)\end{array}$ & $\begin{array}{c}0.23 \\
(0.20)\end{array}$ & $\begin{array}{c}0.57 \\
(0.45)\end{array}$ \\
\hline 21: Mining, Quarrying, and & -0.43 & $1.32 * *$ & 0.20 & $1.05^{* *}$ \\
\hline Oil and Gas Extraction & $(0.79)$ & $(0.62)$ & $(0.20)$ & $(0.43)$ \\
\hline 22: Utilities & $\begin{array}{l}-0.65 \\
(1.26)\end{array}$ & $\begin{array}{l}-0.50 \\
(1.09)\end{array}$ & $\begin{array}{c}0.45 \\
(0.37)\end{array}$ & $\begin{array}{l}-0.59 \\
(0.76)\end{array}$ \\
\hline 23: Construction & $\begin{array}{c}-0.98 \\
(0.78)\end{array}$ & $\begin{array}{c}1.67^{* * *} \\
(0.61)\end{array}$ & $\begin{array}{c}0.24 \\
(0.20)\end{array}$ & $\begin{array}{c}1.45^{* * *} \\
(0.43)\end{array}$ \\
\hline 31-33: Manufacturing & $\begin{array}{l}-1.41^{*} \\
(0.79)\end{array}$ & $\begin{array}{l}1.12^{*} \\
(0.63)\end{array}$ & $\begin{array}{c}0.21 \\
(0.20)\end{array}$ & $\begin{array}{l}0.98 * * \\
(0.45)\end{array}$ \\
\hline 42: Wholesale Trade & $\begin{array}{c}-0.63 \\
(0.82)\end{array}$ & $\begin{array}{l}1.28^{*} \\
(0.65)\end{array}$ & $\begin{array}{c}0.32 \\
(0.20)\end{array}$ & $\begin{array}{l}0.93^{* *} \\
(0.46)\end{array}$ \\
\hline 44-45: Retail Trade & $\begin{array}{c}-0.82 \\
(0.76)\end{array}$ & $\begin{array}{l}1.10^{*} \\
(0.63)\end{array}$ & $\begin{array}{c}0.23 \\
(0.20)\end{array}$ & $\begin{array}{l}0.84^{*} \\
(0.47)\end{array}$ \\
\hline $\begin{array}{l}\text { 48-49: Transportation and } \\
\text { Warehousing }\end{array}$ & $\begin{array}{l}-1.01 \\
(0.81)\end{array}$ & $\begin{array}{l}1.20^{*} \\
(0.64)\end{array}$ & $\begin{array}{c}0.31 \\
(0.20)\end{array}$ & $\begin{array}{l}0.96 * * \\
(0.44)\end{array}$ \\
\hline 51: Information & $\begin{array}{c}0.27 \\
(1.11)\end{array}$ & $\begin{array}{l}1.36 \\
(0.96)\end{array}$ & $\begin{array}{c}0.06 \\
(0.25)\end{array}$ & $\begin{array}{c}0.56 \\
(0.70)\end{array}$ \\
\hline 52: Finance and Insurance & $\begin{array}{l}-1.01 \\
(0.81)\end{array}$ & $\begin{array}{l}1.20 * * \\
(0.60)\end{array}$ & $\begin{array}{c}0.23 \\
(0.21)\end{array}$ & $\begin{array}{l}1.00 * * \\
(0.47)\end{array}$ \\
\hline $\begin{array}{l}\text { 53: Real Estate, Rental \& } \\
\text { Leasing }\end{array}$ & $\begin{array}{c}-0.49 \\
(0.77)\end{array}$ & $\begin{array}{c}1.82^{* * * *} \\
(0.62)\end{array}$ & $\begin{array}{c}0.23 \\
(0.20)\end{array}$ & $\begin{array}{c}1.58^{* * * *} \\
(0.44)\end{array}$ \\
\hline $\begin{array}{l}\text { 54: Professional, Scientific, and } \\
\text { Technical Services }\end{array}$ & $\begin{array}{r}-0.64 \\
(0.80)\end{array}$ & $\begin{array}{l}1.01^{*} \\
(0.61)\end{array}$ & $\begin{array}{c}0.17 \\
0.20)\end{array}$ & $\begin{array}{l}1.03 * * \\
(0.44)\end{array}$ \\
\hline $\begin{array}{l}\text { 55: Management of Companies } \\
\text { and Enterprises }\end{array}$ & $\begin{array}{c}(0.00) \\
0.79 \\
(1.39)\end{array}$ & $\begin{array}{l}2.30^{*} \\
(1.32)\end{array}$ & $\begin{array}{l}-0.10 \\
(0.40)\end{array}$ & $\begin{array}{l}-0.59 \\
(1.08)\end{array}$ \\
\hline $\begin{array}{l}\text { 56: Administrative Support, } \\
\text { Waste Management and } \\
\text { Remediation Services }\end{array}$ & $\begin{array}{l}-0.68 \\
(0.78)\end{array}$ & $\begin{array}{c}1.71^{* * *} \\
(0.64)\end{array}$ & $\begin{array}{c}0.30 \\
(0.20)\end{array}$ & $\begin{array}{c}1.37 * * * \\
(0.45)\end{array}$ \\
\hline 61: Educational Services & $\begin{array}{c}-0.68 \\
(0.86)\end{array}$ & $\begin{array}{c}0.71 \\
(0.82)\end{array}$ & $\begin{array}{c}0.26 \\
(0.25)\end{array}$ & $\begin{array}{c}0.65 \\
(0.59)\end{array}$ \\
\hline 62: Health Care, Social Assist. & $\begin{array}{l}-1.17 \\
(0.80)\end{array}$ & $\begin{array}{l}1.05^{*} \\
(0.62)\end{array}$ & $\begin{array}{c}0.24 \\
(0.19)\end{array}$ & $\begin{array}{l}0.92 * * \\
(0.43)\end{array}$ \\
\hline $\begin{array}{l}\text { 71: Arts, Entertainment, and } \\
\text { Recreation }\end{array}$ & $\begin{array}{c}-0.68 \\
(0.77)\end{array}$ & $\begin{array}{l}1.48 * * \\
(0.63)\end{array}$ & $\begin{array}{c}0.20 \\
(0.20)\end{array}$ & $\begin{array}{l}1.10^{* *} \\
(0.51)\end{array}$ \\
\hline 72: Accommodation, Food Serv. & $\begin{array}{c}-0.59 \\
(0.87)\end{array}$ & $\begin{array}{l}1.24^{*} \\
(0.69)\end{array}$ & $\begin{array}{c}0.28 \\
(0.21)\end{array}$ & $\begin{array}{c}0.59 \\
(0.46)\end{array}$ \\
\hline 81: Other Services & $\begin{array}{c}-0.88 \\
(0.80)\end{array}$ & $\begin{array}{l}1.04^{*} \\
(0.61)\end{array}$ & $\begin{array}{c}0.22 \\
(0.20)\end{array}$ & $\begin{array}{l}0.88^{*} \\
(0.45)\end{array}$ \\
\hline
\end{tabular}


Table A9. (cont'd)

\begin{tabular}{|c|c|c|c|c|}
\hline State Variables & $\begin{array}{c}(1) \\
\text { Income } \\
\text { Growth Rate }\end{array}$ & $\begin{array}{l}\text { (2) } \\
\text { Employment } \\
\text { Growth Rate }\end{array}$ & $\begin{array}{c}\text { (3) } \\
\text { Poverty } \\
\text { Growth }\end{array}$ & $\begin{array}{c}\text { (4) } \\
\text { Population } \\
\text { Growth Rate }\end{array}$ \\
\hline Arizona & $\begin{array}{l}-0.05 \\
(0.06)\end{array}$ & $\begin{array}{l}-0.08 \\
(0.07)\end{array}$ & $\begin{array}{c}0.01 \\
(0.02)\end{array}$ & $\begin{array}{c}0.00 \\
(0.06)\end{array}$ \\
\hline Arkansas & $\begin{array}{l}-0.03 \\
(0.03)\end{array}$ & $\begin{array}{c}-0.08^{*} \\
(0.04)\end{array}$ & $\begin{array}{c}0.01 \\
(0.01)\end{array}$ & $\begin{array}{l}-0.04 \\
(0.04)\end{array}$ \\
\hline California & $\begin{array}{l}-0.01 \\
(0.05)\end{array}$ & $\begin{array}{l}-0.04 \\
(0.06)\end{array}$ & $\begin{array}{c}-0.05^{* * * *} \\
(0.02)\end{array}$ & $\begin{array}{l}-0.01 \\
(0.05)\end{array}$ \\
\hline Colorado & $\begin{array}{c}0.01 \\
(0.04)\end{array}$ & $\begin{array}{l}-0.03 \\
(0.05)\end{array}$ & $\begin{array}{l}-0.01 \\
(0.02)\end{array}$ & $\begin{array}{c}0.02 \\
(0.04)\end{array}$ \\
\hline Connecticut & $\begin{array}{c}0.06 \\
(0.06)\end{array}$ & $\begin{array}{c}-0.10^{*} \\
(0.05)\end{array}$ & $\begin{array}{c}-0.02 \\
(0.01)\end{array}$ & $\begin{array}{c}-0.10^{* * *} \\
(0.05)\end{array}$ \\
\hline Delaware & $\begin{array}{l}-0.08^{*} \\
(0.05)\end{array}$ & $\begin{array}{l}-0.07 \\
(0.06)\end{array}$ & $\begin{array}{c}0.01 \\
(0.01)\end{array}$ & $\begin{array}{c}0.03 \\
(0.05)\end{array}$ \\
\hline District of Columbia & $\begin{array}{c}0.19 \\
(0.12)\end{array}$ & $\begin{array}{c}-0.29 * \\
(0.16)\end{array}$ & $\begin{array}{l}-0.02 \\
(0.04)\end{array}$ & $\begin{array}{l}-0.24 \\
(0.15)\end{array}$ \\
\hline Florida & $\begin{array}{l}-0.05 \\
(0.03)\end{array}$ & $\begin{array}{c}0.01 \\
(0.03)\end{array}$ & $\begin{array}{c}0.01 \\
(0.01)\end{array}$ & $\begin{array}{c}0.02 \\
(0.03)\end{array}$ \\
\hline Geogia & $\begin{array}{l}-0.02 \\
(0.03)\end{array}$ & $\begin{array}{c}-0.02 \\
(0.03)\end{array}$ & $\begin{array}{c}0.01 \\
(0.01)\end{array}$ & $\begin{array}{l}-0.00 \\
(0.02)\end{array}$ \\
\hline Idaho & $\begin{array}{c}-0.08 \\
(0.05)\end{array}$ & $\begin{array}{c}-0.02 \\
(0.05)\end{array}$ & $\begin{array}{l}-0.02 \\
(0.02)\end{array}$ & $\begin{array}{c}0.04 \\
(0.05)\end{array}$ \\
\hline Illinois & $\begin{array}{l}-0.03 \\
(0.03)\end{array}$ & $\begin{array}{c}-0.07^{*} \\
(0.04)\end{array}$ & $\begin{array}{c}-0.00 \\
(0.01)\end{array}$ & $\begin{array}{c}-0.04 \\
(0.03)\end{array}$ \\
\hline Indiana & $\begin{array}{l}-0.01 \\
(0.03)\end{array}$ & $\begin{array}{l}-0.06^{*} \\
(0.04)\end{array}$ & $\begin{array}{c}-0.01 \\
(0.01)\end{array}$ & $\begin{array}{l}-0.03 \\
(0.03)\end{array}$ \\
\hline Iowa & $\begin{array}{l}-0.01 \\
(0.03)\end{array}$ & $\begin{array}{c}-0.04 \\
(0.04)\end{array}$ & $\begin{array}{l}-0.01 \\
(0.01)\end{array}$ & $\begin{array}{c}0.00 \\
(0.03)\end{array}$ \\
\hline Kansas & $\begin{array}{l}-0.03 \\
(0.03)\end{array}$ & $\begin{array}{c}-0.07^{*} \\
(0.04)\end{array}$ & $\begin{array}{c}-0.01 \\
(0.01)\end{array}$ & $\begin{array}{l}-0.03 \\
(0.03)\end{array}$ \\
\hline Kentucky & $\begin{array}{l}-0.02 \\
(0.03)\end{array}$ & $\begin{array}{c}-0.09 * * * \\
(0.03)\end{array}$ & $\begin{array}{c}0.00 \\
(0.01)\end{array}$ & $\begin{array}{c}-0.04 \\
(0.03)\end{array}$ \\
\hline Louisiana & $\begin{array}{c}0.03 \\
(0.03)\end{array}$ & $\begin{array}{c}-0.04 \\
(0.07)\end{array}$ & $\begin{array}{c}-0.01 \\
(0.01)\end{array}$ & $\begin{array}{l}-0.03 \\
(0.05)\end{array}$ \\
\hline Maine & $\begin{array}{c}-0.10^{* * *} \\
(0.04)\end{array}$ & $\begin{array}{l}-0.07 \\
(0.05)\end{array}$ & $\begin{array}{c}0.01 \\
(0.01)\end{array}$ & $\begin{array}{l}-0.01 \\
(0.05)\end{array}$ \\
\hline Maryland & $\begin{array}{l}-0.02 \\
(0.04)\end{array}$ & $\begin{array}{c}-0.09^{* *} \\
(0.04)\end{array}$ & $\begin{array}{l}-0.01 \\
(0.01)\end{array}$ & $\begin{array}{c}-0.08^{* *} \\
(0.04)\end{array}$ \\
\hline Massachusetts & $\begin{array}{l}-0.01 \\
(0.07)\end{array}$ & $\begin{array}{c}-0.15^{* * *} \\
(0.04)\end{array}$ & $\begin{array}{c}-0.00 \\
(0.01)\end{array}$ & $\begin{array}{c}-0.10^{* *} \\
(0.04)\end{array}$ \\
\hline Michigan & $\begin{array}{c}-0.07^{* *} \\
(0.03)\end{array}$ & $\begin{array}{c}-0.06^{*} \\
(0.04)\end{array}$ & $\begin{array}{l}-0.00 \\
(0.01)\end{array}$ & $\begin{array}{c}0.00 \\
(0.03)\end{array}$ \\
\hline
\end{tabular}


Table A9. (cont'd)

\begin{tabular}{|c|c|c|c|c|}
\hline State Variables & $\begin{array}{c}(1) \\
\text { Income } \\
\text { Growth Rate }\end{array}$ & $\begin{array}{c}\text { (2) } \\
\text { Employment } \\
\text { Growth Rate }\end{array}$ & $\begin{array}{l}\text { (3) } \\
\text { Poverty Rate } \\
\text { Growth }\end{array}$ & $\begin{array}{c}\text { (4) } \\
\text { Population } \\
\text { Growth Rate }\end{array}$ \\
\hline Minnesota & $\begin{array}{c}-0.03 \\
(0.03)\end{array}$ & $\begin{array}{c}-0.03 \\
(0.04)\end{array}$ & $\begin{array}{c}-0.00 \\
(0.01)\end{array}$ & $\begin{array}{c}0.01 \\
(0.03)\end{array}$ \\
\hline Mississippi & $\begin{array}{l}-0.04 \\
(0.03)\end{array}$ & $\begin{array}{l}-0.01 \\
(0.03)\end{array}$ & $\begin{array}{c}0.01 \\
(0.01)\end{array}$ & $\begin{array}{c}0.02 \\
(0.02)\end{array}$ \\
\hline Missouri & $\begin{array}{l}-0.02 \\
(0.03)\end{array}$ & $\begin{array}{l}-0.01 \\
(0.04)\end{array}$ & $\begin{array}{c}-0.00 \\
(0.01)\end{array}$ & $\begin{array}{c}0.01 \\
(0.03)\end{array}$ \\
\hline Montana & $\begin{array}{l}-0.06 \\
(0.05)\end{array}$ & $\begin{array}{l}-0.00 \\
(0.05)\end{array}$ & $\begin{array}{c}0.00 \\
(0.02)\end{array}$ & $\begin{array}{c}0.03 \\
(0.04)\end{array}$ \\
\hline Nebraska & $\begin{array}{c}-0.07^{* * *} \\
(0.04)\end{array}$ & $\begin{array}{l}-0.06 \\
(0.04)\end{array}$ & $\begin{array}{c}0.00 \\
(0.01)\end{array}$ & $\begin{array}{l}-0.00 \\
(0.03)\end{array}$ \\
\hline Nevada & $\begin{array}{c}0.03 \\
(0.06)\end{array}$ & $\begin{array}{c}0.08 \\
(0.07)\end{array}$ & $\begin{array}{l}-0.03 \\
(0.02)\end{array}$ & $\begin{array}{c}0.07 \\
(0.06)\end{array}$ \\
\hline New Hampshire & $\begin{array}{l}-0.04 \\
(0.05)\end{array}$ & $\begin{array}{c}-0.13^{* * *} \\
(0.05)\end{array}$ & $\begin{array}{l}-0.00 \\
(0.01)\end{array}$ & $\begin{array}{c}-0.08^{*} \\
(0.05)\end{array}$ \\
\hline New Jersey & $\begin{array}{c}0.05 \\
(0.04)\end{array}$ & $\begin{array}{c}-0.12 * * * \\
(0.04)\end{array}$ & $\begin{array}{c}-0.01 \\
(0.01)\end{array}$ & $\begin{array}{c}-0.12 * * * \\
(0.04)\end{array}$ \\
\hline New Mexico & $\begin{array}{l}-0.02 \\
(0.05)\end{array}$ & $\begin{array}{l}-0.06 \\
(0.06)\end{array}$ & $\begin{array}{c}-0.02 \\
(0.02)\end{array}$ & $\begin{array}{l}-0.01 \\
(0.05)\end{array}$ \\
\hline New York & $\begin{array}{c}-0.02 \\
(0.04)\end{array}$ & $\begin{array}{l}-0.07^{*} \\
(0.04)\end{array}$ & $\begin{array}{c}-0.01 \\
(0.01)\end{array}$ & $\begin{array}{l}-0.04 \\
(0.03)\end{array}$ \\
\hline North Carolina & $\begin{array}{l}-0.03 \\
(0.03)\end{array}$ & $\begin{array}{l}-0.04 \\
(0.03)\end{array}$ & $\begin{array}{c}-0.00 \\
(0.01)\end{array}$ & $\begin{array}{c}0.01 \\
(0.03)\end{array}$ \\
\hline North Dakota & $\begin{array}{l}-0.02 \\
(0.05)\end{array}$ & $\begin{array}{l}-0.01 \\
(0.05)\end{array}$ & $\begin{array}{l}-0.02 \\
(0.01)\end{array}$ & $\begin{array}{c}0.02 \\
(0.04)\end{array}$ \\
\hline Ohio & $\begin{array}{l}-0.01 \\
(0.03)\end{array}$ & $\begin{array}{l}-0.05 \\
(0.04)\end{array}$ & $\begin{array}{c}-0.01 \\
(0.01)\end{array}$ & $\begin{array}{l}-0.00 \\
(0.03)\end{array}$ \\
\hline Oklahoma & $\begin{array}{l}-0.01 \\
(0.04)\end{array}$ & $\begin{array}{l}-0.04 \\
(0.04)\end{array}$ & $\begin{array}{c}-0.00 \\
(0.01)\end{array}$ & $\begin{array}{c}0.02 \\
(0.04)\end{array}$ \\
\hline Oregon & $\begin{array}{c}-0.03 \\
(0.05)\end{array}$ & $\begin{array}{c}-0.03 \\
(0.05)\end{array}$ & $\begin{array}{c}-0.03 \\
(0.02)\end{array}$ & $\begin{array}{c}0.01 \\
(0.05)\end{array}$ \\
\hline Pennsylvania & $\begin{array}{l}-0.04 \\
(0.03)\end{array}$ & $\begin{array}{c}-0.08^{* * *} \\
(0.04)\end{array}$ & $\begin{array}{c}-0.01 \\
(0.01)\end{array}$ & $\begin{array}{c}-0.06^{*} \\
(0.03)\end{array}$ \\
\hline Rhode Island & $\begin{array}{c}0.01 \\
(0.06)\end{array}$ & $\begin{array}{c}-0.17^{* * *} \\
(0.05)\end{array}$ & $\begin{array}{l}-0.01 \\
(0.01)\end{array}$ & $\begin{array}{c}-0.17^{* * *} \\
(0.05)\end{array}$ \\
\hline South Carolina & $\begin{array}{l}-0.05^{*} \\
(0.03)\end{array}$ & $\begin{array}{l}-0.03 \\
(0.03)\end{array}$ & $\begin{array}{c}0.01 \\
(0.01)\end{array}$ & $\begin{array}{c}0.04 \\
(0.03)\end{array}$ \\
\hline South Dakota & $\begin{array}{l}-0.03 \\
(0.04)\end{array}$ & $\begin{array}{c}0.00 \\
(0.05)\end{array}$ & $\begin{array}{c}0.01 \\
(0.01)\end{array}$ & $\begin{array}{l}0.08 * * \\
(0.04)\end{array}$ \\
\hline Tennessee & $\begin{array}{c}-0.01 \\
(0.02)\end{array}$ & $\begin{array}{c}-0.07^{* * *} \\
(0.03)\end{array}$ & $\begin{array}{c}0.01 \\
(0.01)\end{array}$ & $\begin{array}{l}-0.01 \\
(0.03)\end{array}$ \\
\hline
\end{tabular}


Table A9 (cont'd)

\begin{tabular}{lcccc}
\hline \multirow{2}{*}{ State Variables } & $\begin{array}{c}(1) \\
\text { Income } \\
\text { Growth Rate }\end{array}$ & $\begin{array}{c}(2) \\
\text { Employment } \\
\text { Growth Rate }\end{array}$ & $\begin{array}{c}(3) \\
\text { Poverty Rate } \\
\text { Growth }\end{array}$ & $\begin{array}{c}(4) \\
\text { Population } \\
\text { Growth Rate }\end{array}$ \\
\hline \multirow{2}{*}{ Texas } & & & & \\
& -0.03 & -0.05 & 0.01 & -0.00 \\
Utah & $(0.03)$ & $(0.05)$ & $(0.01)$ & $(0.04)$ \\
Vermont & -0.03 & 0.01 & -0.02 & 0.06 \\
Virginia & $(0.06)$ & $(0.06)$ & $(0.02)$ & $(0.05)$ \\
& -0.03 & $-0.16^{* * *}$ & -0.00 & $-0.13^{* * *}$ \\
Washington & $(0.05)$ & $(0.04)$ & $(0.01)$ & $(0.04)$ \\
West Virginia & 0.01 & $-0.06^{*}$ & -0.01 & -0.03 \\
Wisconsin & $(0.03)$ & $(0.03)$ & $(0.01)$ & $(0.03)$ \\
Wyoming & -0.05 & -0.05 & -0.02 & 0.06 \\
& $(0.05)$ & $(0.06)$ & $(0.02)$ & $(0.05)$ \\
& -0.03 & -0.03 & $-0.02 *$ & 0.00 \\
& $(0.03)$ & $(0.04)$ & $(0.01)$ & $(0.03)$ \\
& -0.01 & -0.04 & 0.00 & 0.01 \\
& $(0.03)$ & $(0.04)$ & $(0.01)$ & $(0.03)$ \\
& 0.02 & 0.05 & $-0.02 *$ & $0.09^{* *}$ \\
& $(0.04)$ & $(0.05)$ & $(0.01)$ & $(0.04)$ \\
\hline
\end{tabular}


Table A9 (cont'd)

\begin{tabular}{|c|c|c|c|c|}
\hline Spatial Lags of County Variables & $\begin{array}{c}\text { (1) } \\
\text { Income } \\
\text { Growth Rate }\end{array}$ & $\begin{array}{l}\text { (2) } \\
\text { Employment } \\
\text { Growth Rate }\end{array}$ & $\begin{array}{c}\text { (3) } \\
\text { Poverty Rate } \\
\text { Growth }\end{array}$ & $\begin{array}{c}\text { (4) } \\
\text { Population } \\
\text { Growth Rate }\end{array}$ \\
\hline Per capita income & $\begin{array}{l}-0.00^{*} \\
(0.00)\end{array}$ & $\begin{array}{l}-0.00 \\
(0.00)\end{array}$ & $\begin{array}{c}-0.00 * * \\
(0.00)\end{array}$ & $\begin{array}{l}-0.00 \\
(0.00)\end{array}$ \\
\hline Employment & $\begin{array}{c}-0.00 * * * \\
(0.00)\end{array}$ & $\begin{array}{l}-0.00 \\
(0.00)\end{array}$ & $\begin{array}{c}0.00 * * * \\
(0.00)\end{array}$ & $\begin{array}{l}-0.00^{*} \\
(0.00)\end{array}$ \\
\hline Poverty rate & $\begin{array}{c}-0.01 \\
(0.01)\end{array}$ & $\begin{array}{l}-0.01 \\
(0.01)\end{array}$ & $\begin{array}{c}-0.01^{* * *} \\
(0.00)\end{array}$ & $\begin{array}{l}-0.01 \\
(0.01)\end{array}$ \\
\hline Population & $\begin{array}{l}0.00 * \\
(0.00)\end{array}$ & $\begin{array}{c}0.00 \\
(0.00)\end{array}$ & $\begin{array}{c}-0.00 * * * \\
(0.00)\end{array}$ & $\begin{array}{l}-0.00 \\
(0.00)\end{array}$ \\
\hline Population squared & $\begin{array}{c}-0.00 * * * \\
(0.00)\end{array}$ & $\begin{array}{c}0.00 * * \\
(0.00)\end{array}$ & $\begin{array}{c}0.00 * * * \\
(0.00)\end{array}$ & $\begin{array}{c}0.00 * * * \\
(0.00)\end{array}$ \\
\hline Population density & $\begin{array}{l}-0.00 \\
(0.00)\end{array}$ & $\begin{array}{l}0.00 * \\
(0.00)\end{array}$ & $\begin{array}{c}0.00 * * \\
(0.00)\end{array}$ & $\begin{array}{c}0.00 \\
(0.00)\end{array}$ \\
\hline Average household size & $\begin{array}{c}0.00 \\
(0.00)\end{array}$ & $\begin{array}{c}0.00 \\
(0.00)\end{array}$ & $\begin{array}{l}-0.00 \\
(0.00)\end{array}$ & $\begin{array}{c}0.01^{* *} \\
(0.00)\end{array}$ \\
\hline \% headed by single female & $\begin{array}{l}-0.01 \\
(0.01)\end{array}$ & $\begin{array}{c}0.00 \\
(0.01)\end{array}$ & $\begin{array}{c}0.01 * * \\
(0.00)\end{array}$ & $\begin{array}{c}0.00 \\
(0.01)\end{array}$ \\
\hline Median age & $\begin{array}{l}0.00 * \\
(0.00)\end{array}$ & $\begin{array}{l}-0.00 \\
(0.00)\end{array}$ & $\begin{array}{l}-0.00 \\
(0.00)\end{array}$ & $\begin{array}{l}-0.00 \\
(0.00)\end{array}$ \\
\hline Median age squared & $\begin{array}{l}-0.00 \\
(0.00)\end{array}$ & $\begin{array}{c}0.00 \\
(0.00)\end{array}$ & $\begin{array}{c}0.00 \\
(0.00)\end{array}$ & $\begin{array}{c}0.00 \\
(0.00)\end{array}$ \\
\hline Female population & $\begin{array}{l}-0.00 \\
(0.00)\end{array}$ & $\begin{array}{l}-0.00 \\
(0.00)\end{array}$ & $\begin{array}{c}0.00 * * \\
(0.00)\end{array}$ & $\begin{array}{c}0.00 \\
(0.00)\end{array}$ \\
\hline Female population squared & $\begin{array}{c}0.00 * * * \\
(0.00)\end{array}$ & $\begin{array}{c}-0.00 * * \\
(0.00)\end{array}$ & $\begin{array}{c}-0.00 * * * \\
(0.00)\end{array}$ & $\begin{array}{c}-0.00 * * * \\
(0.00)\end{array}$ \\
\hline Asian population & $\begin{array}{c}0.00 \\
(0.00)\end{array}$ & $\begin{array}{l}-0.00 \\
(0.00)\end{array}$ & $\begin{array}{c}-0.00^{* *} \\
(0.00)\end{array}$ & $\begin{array}{l}-0.00 \\
(0.00)\end{array}$ \\
\hline Asian population squared & $\begin{array}{l}-0.00 \\
(0.00)\end{array}$ & $\begin{array}{c}0.00 \\
(0.00)\end{array}$ & $\begin{array}{c}0.00 \\
(0.00)\end{array}$ & $\begin{array}{l}-0.00 \\
(0.00)\end{array}$ \\
\hline Black population & $\begin{array}{c}0.00 \\
(0.00)\end{array}$ & $\begin{array}{l}-0.00 * \\
(0.00)\end{array}$ & $\begin{array}{l}-0.00 \\
(0.00)\end{array}$ & $\begin{array}{c}-0.00 * * * \\
(0.00)\end{array}$ \\
\hline Black population squared & $\begin{array}{c}-0.00 * * * \\
(0.00)\end{array}$ & $\begin{array}{c}0.00 \\
(0.00)\end{array}$ & $\begin{array}{c}0.00 * * * \\
(0.00)\end{array}$ & $\begin{array}{c}0.00 * * * \\
(0.00)\end{array}$ \\
\hline Hispanic population & $\begin{array}{l}-0.00 \\
(0.00)\end{array}$ & $\begin{array}{c}-0.00^{* *} \\
(0.00)\end{array}$ & $\begin{array}{c}0.00^{* * * *} \\
(0.00)\end{array}$ & $\begin{array}{c}0.00 \\
(0.00)\end{array}$ \\
\hline Hispanic population squared & $\begin{array}{c}0.00 \\
(0.00)\end{array}$ & $\begin{array}{l}-0.00 \\
(0.00) \\
\end{array}$ & $\begin{array}{c}-0.00 * * \\
(0.00)\end{array}$ & $\begin{array}{l}-0.00 \\
(0.00) \\
\end{array}$ \\
\hline
\end{tabular}


Table A9. (cont'd)

\begin{tabular}{lcccc}
\hline \multirow{2}{*}{ Spatial Lags of County Variables } & $\begin{array}{c}(1) \\
\text { Income } \\
\text { Growth Rate }\end{array}$ & $\begin{array}{c}(2) \\
\text { Employment } \\
\text { Growth Rate }\end{array}$ & $\begin{array}{c}(3) \\
\text { Poverty Rate } \\
\text { Growth }\end{array}$ & $\begin{array}{c}(4) \\
\text { Population } \\
\text { Growth Rate }\end{array}$ \\
\hline \% owner's education: high school & $0.02^{* * *}$ & $0.02^{* * *}$ & $-0.00^{*}$ & 0.01 \\
Some college & $(0.01)$ & $(0.01)$ & $(0.00)$ & $(0.00)$ \\
& 0.00 & -0.00 & 0.00 & -0.00 \\
Trade school degree & $(0.01)$ & $(0.01)$ & $(0.00)$ & $(0.01)$ \\
Associates degree & 0.01 & $0.02^{* *}$ & $-0.01 * * *$ & 0.00 \\
& $(0.01)$ & $(0.01)$ & $(0.00)$ & $(0.01)$ \\
Bachelor's degree & 0.01 & $0.02^{*}$ & -0.00 & 0.00 \\
Graduate school degree & $(0.01)$ & $(0.01)$ & $(0.00)$ & $(0.01)$ \\
Taxes per capita & 0.00 & $0.02^{*}$ & 0.00 & $0.02^{* *}$ \\
& $(0.01)$ & $(0.01)$ & $(0.00)$ & $(0.01)$ \\
Education spending & -0.01 & -0.00 & -0.00 & -0.01 \\
& $(0.01)$ & $(0.01)$ & $(0.00)$ & $(0.01)$ \\
Highway spending & -0.00 & 0.00 & 0.00 & -0.00 \\
& $(0.00)$ & $(0.00)$ & $(0.00)$ & $(0.00)$ \\
Labor force participation rate & -0.00 & $-0.00^{* * *}$ & -0.00 & -0.00 \\
Build permits & $(0.00)$ & $(0.00)$ & $(0.00)$ & $(0.00)$ \\
& $0.00^{*}$ & $0.00^{* * *}$ & -0.00 & 0.00 \\
& $(0.00)$ & $(0.00)$ & $(0.00)$ & $(0.00)$ \\
& $0.01 *$ & $0.01 *$ & -0.00 & 0.01 \\
& $(0.01)$ & $(0.01)$ & $(0.00)$ & $(0.01)$ \\
& $-0.00^{* *}$ & 0.00 & 0.00 & $0.00^{* * *}$ \\
& $(0.00)$ & $(0.00)$ & $(0.00)$ & $(0.00)$ \\
\hline
\end{tabular}


Table A9. (cont'd)

\begin{tabular}{|c|c|c|c|c|}
\hline Spatial Lags of NAICS Sector & $\begin{array}{c}(1) \\
\text { Income } \\
\text { Growth Rate }\end{array}$ & $\begin{array}{c}\text { (2) } \\
\text { Employment } \\
\text { Growth Rate }\end{array}$ & $\begin{array}{l}\text { (3) } \\
\text { Poverty Rate } \\
\text { Growth }\end{array}$ & $\begin{array}{c}\text { (4) } \\
\text { Population } \\
\text { Growth Rate }\end{array}$ \\
\hline Employment under 11: Ag., & $-0.00 *$ & $0.00^{*}$ & 0.00 & 0.00 \\
\hline Forestry, Fishing and Hunting & $(0.00)$ & $(0.00)$ & $(0.00)$ & $(0.00)$ \\
\hline 21: Mining, Quarrying, and & $0.00 * * *$ & 0.00 & $-0.00 * * *$ & $-0.00 *$ \\
\hline Oil and Gas Extraction & $(0.00)$ & $(0.00)$ & $(0.00)$ & $(0.00)$ \\
\hline 22: Utilities & $\begin{array}{l}0.00^{*} \\
(0.00)\end{array}$ & $\begin{array}{c}0.00 \\
(0.00)\end{array}$ & $\begin{array}{c}-0.00 * * * \\
(0.00)\end{array}$ & $\begin{array}{l}-0.00 \\
(0.00)\end{array}$ \\
\hline 23: Construction & $\begin{array}{c}-0.00 * * \\
(0.00)\end{array}$ & $\begin{array}{l}-0.00 \\
(0.00)\end{array}$ & $\begin{array}{c}0.00^{* * *} \\
(0.00)\end{array}$ & $\begin{array}{c}0.00 \\
(0.00)\end{array}$ \\
\hline 31-33: Manufacturing & $\begin{array}{l}-0.00 \\
(0.00)\end{array}$ & $\begin{array}{c}-0.00^{* * * *} \\
(0.00)\end{array}$ & $\begin{array}{c}0.00 \\
(0.00)\end{array}$ & $\begin{array}{c}-0.00^{* * * *} \\
(0.00)\end{array}$ \\
\hline 42: Wholesale Trade & $\begin{array}{l}-0.00 \\
(0.00)\end{array}$ & $\begin{array}{c}0.00^{* * *} \\
(0.00)\end{array}$ & $\begin{array}{c}-0.00 * * * \\
(0.00)\end{array}$ & $\begin{array}{l}0.00^{* *} \\
(0.00)\end{array}$ \\
\hline 44-45: Retail Trade & $\begin{array}{l}0.00^{*} \\
(0.00)\end{array}$ & $\begin{array}{l}-0.00 \\
(0.00)\end{array}$ & $\begin{array}{c}0.00 \\
(0.00)\end{array}$ & $\begin{array}{l}-0.00 \\
(0.00)\end{array}$ \\
\hline $\begin{array}{l}\text { 48-49: Transportation and } \\
\text { Warehousing }\end{array}$ & $\begin{array}{l}0.00^{*} \\
(0.00)\end{array}$ & $\begin{array}{c}0.00 \\
(0.00)\end{array}$ & $\begin{array}{l}-0.00 \\
(0.00)\end{array}$ & $\begin{array}{c}0.00 \\
(0.00)\end{array}$ \\
\hline 51: Information & $\begin{array}{c}0.00 \\
(0.00)\end{array}$ & $\begin{array}{l}-0.00 \\
(0.00)\end{array}$ & $\begin{array}{l}-0.00 \\
(0.00)\end{array}$ & $\begin{array}{c}-0.00 * * \\
(0.00)\end{array}$ \\
\hline 52: Finance and Insurance & $\begin{array}{c}0.00 \\
(0.00)\end{array}$ & $\begin{array}{c}0.00 \\
(0.00)\end{array}$ & $\begin{array}{l}0.00^{* *} \\
(0.00)\end{array}$ & $\begin{array}{l}0.00^{*} \\
(0.00)\end{array}$ \\
\hline $\begin{array}{l}\text { 53: Real Estate, Rental \& } \\
\text { Leasing }\end{array}$ & $\begin{array}{l}-0.00 \\
(0.00)\end{array}$ & $\begin{array}{l}-0.00 \\
(0.00)\end{array}$ & $\begin{array}{l}-0.00 \\
(0.00)\end{array}$ & $\begin{array}{c}-0.00^{* * * *} \\
(0.00)\end{array}$ \\
\hline $\begin{array}{l}\text { 54: Professional, Scientific, and } \\
\text { Technical Services }\end{array}$ & $\begin{array}{l}-0.00 \\
(0.00)\end{array}$ & $\begin{array}{c}0.00 \\
(0.00)\end{array}$ & $\begin{array}{c}0.00 \\
(0.00)\end{array}$ & $\begin{array}{l}0.00 * * \\
(0.00)\end{array}$ \\
\hline $\begin{array}{l}\text { 55: Management of Companies } \\
\text { and Enterprises }\end{array}$ & $\begin{array}{c}0.00^{* * *} \\
(0.00)\end{array}$ & $\begin{array}{c}0.00 \\
(0.00)\end{array}$ & $\begin{array}{l}-0.00 \\
(0.00)\end{array}$ & $\begin{array}{c}0.00 \\
(0.00)\end{array}$ \\
\hline $\begin{array}{l}\text { 56: Administrative Support, } \\
\text { Waste Management and } \\
\text { Remediation Services }\end{array}$ & $\begin{array}{c}0.00 \\
(0.00)\end{array}$ & $\begin{array}{c}-0.00 \\
(0.00)\end{array}$ & $\begin{array}{l}-0.00 \\
(0.00)\end{array}$ & $\begin{array}{c}-0.00 \\
(0.00)\end{array}$ \\
\hline 61: Educational Services & $\begin{array}{c}-0.00 \\
(0.00)\end{array}$ & $\begin{array}{l}-0.00 \\
(0.00)\end{array}$ & $\begin{array}{c}0.00 \\
(0.00)\end{array}$ & $\begin{array}{c}-0.00^{*} \\
(0.00)\end{array}$ \\
\hline 62: Health Care, Social Assist. & $\begin{array}{l}-0.00 \\
(0.00)\end{array}$ & $\begin{array}{c}0.00 \\
(0.00)\end{array}$ & $\begin{array}{c}0.00^{* *} \\
(0.00)\end{array}$ & $\begin{array}{l}0.00^{*} \\
(0.00)\end{array}$ \\
\hline $\begin{array}{l}\text { 71: Arts, Entertainment, and } \\
\text { Recreation }\end{array}$ & $\begin{array}{c}-0.00 \\
(0.00)\end{array}$ & $\begin{array}{c}-0.00 * * * \\
(0.00)\end{array}$ & $\begin{array}{l}0.00 * * \\
(0.00)\end{array}$ & $\begin{array}{c}-0.00^{* *} \\
(0.00)\end{array}$ \\
\hline 72: Accommodation, Food Serv. & $\begin{array}{c}-0.00 \\
(0.00)\end{array}$ & $\begin{array}{c}0.00 \\
(0.00)\end{array}$ & $\begin{array}{l}-0.00 \\
(0.00)\end{array}$ & $\begin{array}{c}0.00 \\
(0.00)\end{array}$ \\
\hline 81: Other Services & $\begin{array}{l}0.00^{* *} \\
(0.00)\end{array}$ & $\begin{array}{c}0.00^{* *} \\
(0.00)\end{array}$ & $\begin{array}{c}-0.00 * * * \\
(0.00)\end{array}$ & $\begin{array}{c}0.00^{* * *} \\
(0.00)\end{array}$ \\
\hline
\end{tabular}


Table A9. (cont'd)

\begin{tabular}{|c|c|c|c|c|}
\hline Spatial Lags or NAICS Sector & $\begin{array}{c}(1) \\
\text { Income } \\
\text { Growth Rate }\end{array}$ & $\begin{array}{c}\text { (2) } \\
\text { Employment } \\
\text { Growth Rate }\end{array}$ & $\begin{array}{l}\text { (3) } \\
\text { Poverty Rate } \\
\text { Growth }\end{array}$ & $\begin{array}{c}\text { (4) } \\
\text { Population } \\
\text { Growth Rate }\end{array}$ \\
\hline $\begin{array}{l}\% \text { establishments under 11: Ag., } \\
\text { Forestry Fishing Hunting }\end{array}$ & $\begin{array}{l}-0.03^{* *} \\
(0.02)\end{array}$ & $\begin{array}{l}-0.03 \\
(0.02)\end{array}$ & $\begin{array}{l}0.01^{* *} \\
(0.01)\end{array}$ & $\begin{array}{l}-0.03^{*} \\
(0.02)\end{array}$ \\
\hline 21: Mining, Quarrying, and & 0.00 & 0.00 & 0.01 & -0.00 \\
\hline Oil and Gas Extraction & $(0.02)$ & $(0.02)$ & $(0.01)$ & $(0.02)$ \\
\hline 22: Utilities & $\begin{array}{l}-0.03 \\
(0.12)\end{array}$ & $\begin{array}{c}0.09 \\
(0.14)\end{array}$ & $\begin{array}{c}0.09 * * \\
(0.04)\end{array}$ & $\begin{array}{c}-0.14 \\
(0.12)\end{array}$ \\
\hline 23: Construction & $\begin{array}{l}-0.03^{*} \\
(0.02)\end{array}$ & $\begin{array}{l}-0.01 \\
(0.02)\end{array}$ & $\begin{array}{l}0.01 * * \\
(0.01)\end{array}$ & $\begin{array}{c}-0.00 \\
(0.02)\end{array}$ \\
\hline 31-33: Manufacturing & $\begin{array}{c}-0.15^{* * *} \\
(0.03)\end{array}$ & $\begin{array}{c}-0.08 * * \\
(0.03)\end{array}$ & $\begin{array}{c}0.03^{* * *} \\
(0.01)\end{array}$ & $\begin{array}{c}0.00 \\
(0.03)\end{array}$ \\
\hline 42: Wholesale Trade & $\begin{array}{c}0.02 \\
(0.04)\end{array}$ & $\begin{array}{l}-0.05 \\
(0.05)\end{array}$ & $\begin{array}{c}0.02 \\
(0.01)\end{array}$ & $\begin{array}{c}-0.04 \\
(0.04)\end{array}$ \\
\hline 44-45: Retail Trade & $\begin{array}{l}-0.01 \\
(0.02)\end{array}$ & $\begin{array}{c}0.00 \\
(0.02)\end{array}$ & $\begin{array}{c}0.01 \\
(0.01)\end{array}$ & $\begin{array}{l}-0.02 \\
(0.02)\end{array}$ \\
\hline $\begin{array}{l}\text { 48-49: Transportation and } \\
\text { Warehousing }\end{array}$ & $\begin{array}{c}-0.03 \\
(0.02)\end{array}$ & $\begin{array}{c}0.03 \\
(0.03)\end{array}$ & $\begin{array}{c}0.01 \\
(0.01)\end{array}$ & $\begin{array}{c}0.03 \\
(0.02)\end{array}$ \\
\hline 51: Information & $\begin{array}{c}0.07 \\
(0.08)\end{array}$ & $\begin{array}{c}0.01 \\
(0.10)\end{array}$ & $\begin{array}{c}0.07 * * \\
(0.03)\end{array}$ & $\begin{array}{l}-0.01 \\
(0.08)\end{array}$ \\
\hline 52: Finance and Insurance & $\begin{array}{c}-0.05 \\
(0.04)\end{array}$ & $\begin{array}{c}-0.09 * * \\
(0.04)\end{array}$ & $\begin{array}{c}-0.02 \\
(0.01)\end{array}$ & $\begin{array}{l}-0.03 \\
(0.03)\end{array}$ \\
\hline $\begin{array}{l}\text { 53: Real Estate, Rental \& } \\
\text { Leasing }\end{array}$ & $\begin{array}{c}-0.00 \\
(0.02)\end{array}$ & $\begin{array}{l}0.07 * * \\
(0.03)\end{array}$ & $\begin{array}{c}0.01 \\
(0.01)\end{array}$ & $\begin{array}{c}0.01 \\
(0.02)\end{array}$ \\
\hline $\begin{array}{l}\text { 54: Professional, Scientific, and } \\
\text { Technical Services }\end{array}$ & $\begin{array}{c}-0.01 \\
(0.03)\end{array}$ & $\begin{array}{l}-0.03 \\
(0.04)\end{array}$ & $\begin{array}{c}0.02 \\
(0.01)\end{array}$ & $\begin{array}{c}-0.03 \\
(0.03)\end{array}$ \\
\hline $\begin{array}{l}\text { 55: Management of Companies } \\
\text { and Enterprises }\end{array}$ & $\begin{array}{c}-0.22 \\
(0.23)\end{array}$ & $\begin{array}{l}-0.26 \\
(0.25)\end{array}$ & $\begin{array}{l}0.15^{*} \\
(0.08)\end{array}$ & $\begin{array}{c}-0.45^{* *} \\
(0.19)\end{array}$ \\
\hline $\begin{array}{l}\text { 56: Administrative Support, } \\
\text { Waste Management and } \\
\text { Remediation Services }\end{array}$ & $\begin{array}{c}0.01 \\
(0.03)\end{array}$ & $\begin{array}{c}-0.04 \\
(0.04)\end{array}$ & $\begin{array}{c}0.00 \\
(0.01)\end{array}$ & $\begin{array}{l}-0.05 \\
(0.03)\end{array}$ \\
\hline 61: Educational Services & $\begin{array}{c}0.15^{* * *} \\
(0.06)\end{array}$ & $\begin{array}{c}0.11 \\
(0.07)\end{array}$ & $\begin{array}{c}-0.06^{* * *} \\
(0.02)\end{array}$ & $\begin{array}{c}0.07 \\
(0.06)\end{array}$ \\
\hline 62: Health Care, Social Assist. & $\begin{array}{l}-0.01 \\
(0.02)\end{array}$ & $\begin{array}{l}-0.03 \\
(0.03)\end{array}$ & $\begin{array}{c}0.01 \\
(0.01)\end{array}$ & $\begin{array}{l}-0.02 \\
(0.02)\end{array}$ \\
\hline $\begin{array}{l}\text { 71: Arts, Entertainment, and } \\
\text { Recreation }\end{array}$ & $\begin{array}{c}0.03 \\
(0.03)\end{array}$ & $\begin{array}{c}0.01 \\
(0.04)\end{array}$ & $\begin{array}{c}-0.02 \\
(0.01)\end{array}$ & $\begin{array}{l}-0.02 \\
(0.03)\end{array}$ \\
\hline 72: Accommodation, Food Serv. & $\begin{array}{l}-0.03 \\
(0.03)\end{array}$ & $\begin{array}{l}-0.03 \\
(0.04)\end{array}$ & $\begin{array}{c}0.01 \\
(0.01)\end{array}$ & $\begin{array}{l}-0.03 \\
(0.03)\end{array}$ \\
\hline 81: Other Services & $\begin{array}{c}-0.06 * * * \\
(0.02)\end{array}$ & $\begin{array}{c}0.00 \\
(0.02)\end{array}$ & $\begin{array}{l}0.01^{*} \\
(0.01)\end{array}$ & $\begin{array}{c}0.00 \\
(0.02)\end{array}$ \\
\hline
\end{tabular}


Table A9. (cont'd)

\begin{tabular}{|c|c|c|c|c|}
\hline Spatial Lags of State Variables & $\begin{array}{c}(1) \\
\text { Income } \\
\text { Growth Rate }\end{array}$ & $\begin{array}{c}\text { (2) } \\
\text { Employment } \\
\text { Growth Rate }\end{array}$ & $\begin{array}{l}\text { (3) } \\
\text { Poverty Rate } \\
\text { Growth }\end{array}$ & $\begin{array}{c}\text { (4) } \\
\text { Population } \\
\text { Growth Rate }\end{array}$ \\
\hline Arizona & $\begin{array}{c}0.00 \\
(0.01)\end{array}$ & $\begin{array}{c}0.02 \\
(0.02)\end{array}$ & $\begin{array}{c}-0.01 * * * \\
(0.00)\end{array}$ & $\begin{array}{l}-0.01 \\
(0.02)\end{array}$ \\
\hline Arkansas & $\begin{array}{l}-0.00 \\
(0.00)\end{array}$ & $\begin{array}{c}0.00 \\
(0.00)\end{array}$ & $\begin{array}{c}0.00 \\
(0.00)\end{array}$ & $\begin{array}{c}0.00 \\
(0.00)\end{array}$ \\
\hline California & $\begin{array}{l}0.01^{*} \\
(0.00)\end{array}$ & $\begin{array}{c}0.01^{* * *} \\
(0.00)\end{array}$ & $\begin{array}{c}0.00 \\
(0.00)\end{array}$ & $\begin{array}{c}0.00 \\
(0.00)\end{array}$ \\
\hline Colorado & $\begin{array}{c}-0.00 \\
(0.00)\end{array}$ & $\begin{array}{l}-0.00 \\
(0.00)\end{array}$ & $\begin{array}{l}0.00^{*} \\
(0.00)\end{array}$ & $\begin{array}{l}-0.00 \\
(0.00)\end{array}$ \\
\hline Connecticut & $\begin{array}{l}-0.01^{*} \\
(0.00)\end{array}$ & $\begin{array}{c}0.01 \\
(0.01)\end{array}$ & $\begin{array}{c}0.00 \\
(0.00)\end{array}$ & $\begin{array}{c}0.02^{* * * *} \\
(0.00)\end{array}$ \\
\hline Delaware & $\begin{array}{c}-0.00 \\
(0.01)\end{array}$ & $\begin{array}{c}-0.00 \\
(0.01)\end{array}$ & $\begin{array}{l}-0.00 \\
(0.00)\end{array}$ & $\begin{array}{c}0.01 \\
(0.01)\end{array}$ \\
\hline District of Columbia & $\begin{array}{c}0.00 \\
(0.03)\end{array}$ & $\begin{array}{c}-0.06 * * \\
(0.03)\end{array}$ & $\begin{array}{l}0.02^{*} \\
(0.01)\end{array}$ & $\begin{array}{c}-0.08 * * \\
(0.03)\end{array}$ \\
\hline Florida & $\begin{array}{c}-0.00 \\
(0.00)\end{array}$ & $\begin{array}{c}0.00 \\
(0.00)\end{array}$ & $\begin{array}{l}-0.00 \\
(0.00)\end{array}$ & $\begin{array}{c}0.00 \\
(0.00)\end{array}$ \\
\hline Geogia & $\begin{array}{l}-0.00 \\
(0.00)\end{array}$ & $\begin{array}{l}-0.00 \\
(0.00)\end{array}$ & $\begin{array}{l}0.00^{*} \\
(0.00)\end{array}$ & $\begin{array}{l}-0.00 \\
(0.00)\end{array}$ \\
\hline Idaho & $\begin{array}{l}-0.00^{*} \\
(0.00)\end{array}$ & $\begin{array}{l}-0.00 \\
(0.00)\end{array}$ & $\begin{array}{l}0.00^{* *} \\
(0.00)\end{array}$ & $\begin{array}{l}-0.00^{*} \\
(0.00)\end{array}$ \\
\hline Illinois & $\begin{array}{c}-0.00 * * \\
(0.00)\end{array}$ & $\begin{array}{l}-0.00 \\
(0.00)\end{array}$ & $\begin{array}{c}0.00^{* *} \\
(0.00)\end{array}$ & $\begin{array}{l}-0.00^{*} \\
(0.00)\end{array}$ \\
\hline Indiana & $\begin{array}{c}-0.00 * * * \\
(0.00)\end{array}$ & $\begin{array}{c}-0.00 * * * \\
(0.00)\end{array}$ & $\begin{array}{l}0.00 * * \\
(0.00)\end{array}$ & $\begin{array}{c}-0.00 * * * \\
(0.00)\end{array}$ \\
\hline Iowa & $\begin{array}{c}-0.00^{*} \\
(0.00)\end{array}$ & $\begin{array}{c}-0.00^{*} \\
(0.00)\end{array}$ & $\begin{array}{c}0.00^{* * * *} \\
(0.00)\end{array}$ & $\begin{array}{c}-0.00 * * \\
(0.00)\end{array}$ \\
\hline Kansas & $\begin{array}{l}-0.00^{*} \\
(0.00)\end{array}$ & $\begin{array}{l}-0.00 \\
(0.00)\end{array}$ & $\begin{array}{c}0.00 \\
(0.00)\end{array}$ & $\begin{array}{c}-0.00^{*} \\
(0.00)\end{array}$ \\
\hline Kentucky & $\begin{array}{c}0.00 \\
(0.00)\end{array}$ & $\begin{array}{c}0.00 \\
(0.00)\end{array}$ & $\begin{array}{l}-0.00 \\
(0.00)\end{array}$ & $\begin{array}{l}-0.00 \\
(0.00)\end{array}$ \\
\hline Louisiana & $\begin{array}{c}0.00 \\
(0.00)\end{array}$ & $\begin{array}{c}0.00 \\
(0.00)\end{array}$ & $\begin{array}{l}-0.00 \\
(0.00)\end{array}$ & $\begin{array}{c}0.00 \\
(0.00)\end{array}$ \\
\hline Maine & $\begin{array}{c}-0.00 \\
(0.00)\end{array}$ & $\begin{array}{l}-0.00 \\
(0.00)\end{array}$ & $\begin{array}{l}-0.00 \\
(0.00)\end{array}$ & $\begin{array}{l}-0.00 \\
(0.00)\end{array}$ \\
\hline Maryland & $\begin{array}{c}0.00 \\
(0.00)\end{array}$ & $\begin{array}{c}0.00 \\
(0.00)\end{array}$ & $\begin{array}{c}-0.00 * * \\
(0.00)\end{array}$ & $\begin{array}{c}0.01^{* * * *} \\
(0.00)\end{array}$ \\
\hline Massachusetts & $\begin{array}{l}-0.00 \\
(0.00)\end{array}$ & $\begin{array}{l}-0.00 \\
(0.00)\end{array}$ & $\begin{array}{l}-0.00^{*} \\
(0.00)\end{array}$ & $\begin{array}{l}-0.01 \\
(0.00)\end{array}$ \\
\hline Michigan & $\begin{array}{c}-0.01 * * * \\
(0.00)\end{array}$ & $\begin{array}{c}-0.01 * * * \\
(0.00)\end{array}$ & $\begin{array}{c}0.00^{* * *} \\
(0.00)\end{array}$ & $\begin{array}{c}-0.00^{* * * *} \\
(0.00)\end{array}$ \\
\hline
\end{tabular}


Table A9. (cont'd)

\begin{tabular}{|c|c|c|c|c|}
\hline Spatial Lags of State Variables & $\begin{array}{c}(1) \\
\text { Income } \\
\text { Growth Rate }\end{array}$ & $\begin{array}{l}\text { (2) } \\
\text { Employment } \\
\text { Growth Rate }\end{array}$ & $\begin{array}{c}(3) \\
\text { Poverty Rate } \\
\text { Growth }\end{array}$ & $\begin{array}{c}\text { (4) } \\
\text { Population } \\
\text { Growth Rate }\end{array}$ \\
\hline Minnesota & $\begin{array}{c}-0.00 \\
(0.00)\end{array}$ & $\begin{array}{c}-0.00 * * \\
(0.00)\end{array}$ & $\begin{array}{c}0.00^{* * *} \\
(0.00)\end{array}$ & $\begin{array}{c}-0.00 * * * \\
(0.00)\end{array}$ \\
\hline Mississippi & $\begin{array}{c}0.00 \\
(0.00)\end{array}$ & $\begin{array}{l}-0.00 \\
(0.00)\end{array}$ & $\begin{array}{c}0.00 \\
(0.00)\end{array}$ & $\begin{array}{c}-0.00 * * \\
(0.00)\end{array}$ \\
\hline Missouri & $\begin{array}{l}-0.00 \\
(0.00)\end{array}$ & $\begin{array}{c}-0.00 * * \\
(0.00)\end{array}$ & $\begin{array}{l}0.00^{*} \\
(0.00)\end{array}$ & $\begin{array}{c}-0.00 * * \\
(0.00)\end{array}$ \\
\hline Montana & $\begin{array}{c}-0.00 \\
(0.00)\end{array}$ & $\begin{array}{l}-0.00 \\
(0.00)\end{array}$ & $\begin{array}{l}-0.00 \\
(0.00)\end{array}$ & $\begin{array}{l}-0.00 \\
(0.00)\end{array}$ \\
\hline Nebraska & $\begin{array}{c}-0.00 \\
(0.00)\end{array}$ & $\begin{array}{l}-0.00 \\
(0.00)\end{array}$ & $\begin{array}{c}0.00^{* * *} \\
(0.00)\end{array}$ & $\begin{array}{c}-0.00^{* * *} \\
(0.00)\end{array}$ \\
\hline Nevada & $\begin{array}{c}-0.02 * * \\
(0.01)\end{array}$ & $\begin{array}{c}-0.03^{* * * *} \\
(0.01)\end{array}$ & $\begin{array}{c}0.00^{* * *} \\
(0.00)\end{array}$ & $\begin{array}{c}-0.00 \\
(0.01)\end{array}$ \\
\hline New Hampshire & $\begin{array}{c}-0.01 * * * \\
(0.00)\end{array}$ & $\begin{array}{l}-0.00 \\
(0.00)\end{array}$ & $\begin{array}{c}0.00 \\
(0.00)\end{array}$ & $\begin{array}{c}0.00 \\
(0.00)\end{array}$ \\
\hline New Jersey & $\begin{array}{c}-0.01 * * * \\
(0.00)\end{array}$ & $\begin{array}{l}-0.00 \\
(0.00)\end{array}$ & $\begin{array}{c}0.00^{* * *} \\
(0.00)\end{array}$ & $\begin{array}{l}-0.00 \\
(0.00)\end{array}$ \\
\hline New Mexico & $\begin{array}{c}0.00 \\
(0.00)\end{array}$ & $\begin{array}{c}0.01^{* *} \\
(0.01)\end{array}$ & $\begin{array}{c}0.00 \\
(0.00)\end{array}$ & $\begin{array}{c}0.02^{* * * *} \\
(0.01)\end{array}$ \\
\hline New York & $\begin{array}{c}-0.01^{* * *} \\
(0.00)\end{array}$ & $\begin{array}{c}-0.00 \\
(0.00)\end{array}$ & $\begin{array}{c}0.00 \\
(0.00)\end{array}$ & $\begin{array}{l}-0.00 \\
(0.00)\end{array}$ \\
\hline North Carolina & $\begin{array}{l}-0.00 \\
(0.00)\end{array}$ & $\begin{array}{c}0.00 \\
(0.00)\end{array}$ & $\begin{array}{c}0.00^{* * *} \\
(0.00)\end{array}$ & $\begin{array}{l}0.00^{*} \\
(0.00)\end{array}$ \\
\hline North Dakota & $\begin{array}{c}0.00 \\
(0.00)\end{array}$ & $\begin{array}{c}-0.00 \\
(0.00)\end{array}$ & $\begin{array}{c}0.00^{* * *} \\
(0.00)\end{array}$ & $\begin{array}{l}-0.00^{*} \\
(0.00)\end{array}$ \\
\hline Ohio & $\begin{array}{c}-0.01^{* * * *} \\
(0.00)\end{array}$ & $\begin{array}{c}-0.00 * * \\
(0.00)\end{array}$ & $\begin{array}{c}0.00^{* * *} \\
(0.00)\end{array}$ & $\begin{array}{c}-0.00 * * \\
(0.00)\end{array}$ \\
\hline Oklahoma & $\begin{array}{l}-0.00 \\
(0.00)\end{array}$ & $\begin{array}{l}-0.00 \\
(0.00)\end{array}$ & $\begin{array}{c}0.00 \\
(0.00)\end{array}$ & $\begin{array}{c}-0.00^{* *} \\
(0.00)\end{array}$ \\
\hline Oregon & $\begin{array}{l}-0.00^{*} \\
(0.00)\end{array}$ & $\begin{array}{l}-0.00 \\
(0.00)\end{array}$ & $\begin{array}{l}0.00^{*} \\
(0.00)\end{array}$ & $\begin{array}{c}0.00 \\
(0.00)\end{array}$ \\
\hline Pennsylvania & $\begin{array}{c}-0.00^{* * *} \\
(0.00)\end{array}$ & $\begin{array}{l}-0.00 \\
(0.00)\end{array}$ & $\begin{array}{c}0.00 \\
(0.00)\end{array}$ & $\begin{array}{l}-0.00 \\
(0.00)\end{array}$ \\
\hline Rhode Island & $\begin{array}{c}0.00 \\
(0.00)\end{array}$ & $\begin{array}{c}0.00 \\
(0.00)\end{array}$ & $\begin{array}{c}-0.00^{*} \\
(0.00)\end{array}$ & $\begin{array}{c}0.00 \\
(0.00)\end{array}$ \\
\hline South Carolina & $\begin{array}{c}0.00 \\
(0.00)\end{array}$ & $\begin{array}{c}0.00 \\
(0.00)\end{array}$ & $\begin{array}{c}0.00 \\
(0.00)\end{array}$ & $\begin{array}{c}0.00 \\
(0.00)\end{array}$ \\
\hline South Dakota & $\begin{array}{l}-0.00 \\
(0.00)\end{array}$ & $\begin{array}{c}-0.01 * * * \\
(0.00)\end{array}$ & $\begin{array}{c}0.00^{* * *} \\
(0.00)\end{array}$ & $\begin{array}{c}-0.01^{* * * *} \\
(0.00)\end{array}$ \\
\hline Tennessee & $\begin{array}{l}-0.00 \\
(0.00)\end{array}$ & $\begin{array}{c}0.00 \\
(0.00)\end{array}$ & $\begin{array}{c}0.00 \\
(0.00)\end{array}$ & $\begin{array}{l}-0.00 \\
(0.00)\end{array}$ \\
\hline
\end{tabular}


Table A9. (cont'd)

\begin{tabular}{lcccc}
\hline \multirow{2}{*}{ Spatial Lags of State Variables } & $\begin{array}{c}(1) \\
\text { Income } \\
\text { Growth Rate }\end{array}$ & $\begin{array}{c}(2) \\
\text { Employment } \\
\text { Growth Rate }\end{array}$ & $\begin{array}{c}(3) \\
\text { Poverty Rate } \\
\text { Growth }\end{array}$ & $\begin{array}{c}(4) \\
\text { Population } \\
\text { Growth Rate }\end{array}$ \\
\hline \multirow{2}{*}{ Texas } & -0.00 & -0.00 & 0.00 & -0.00 \\
Utah & $(0.00)$ & $(0.00)$ & $(0.00)$ & $(0.00)$ \\
Vermont & -0.01 & $-0.01^{* * *}$ & 0.00 & $-0.01^{* * *}$ \\
Virginia & $(0.00)$ & $(0.00)$ & $(0.00)$ & $(0.00)$ \\
& $-0.01^{* *}$ & 0.00 & 0.00 & $0.01^{* *}$ \\
Washington & $(0.00)$ & $(0.00)$ & $(0.00)$ & $(0.00)$ \\
West Virginia & -0.00 & 0.00 & -0.00 & 0.00 \\
& $(0.00)$ & $(0.00)$ & $(0.00)$ & $(0.00)$ \\
Wisconsin & -0.00 & 0.00 & 0.00 & 0.00 \\
& $(0.00)$ & $(0.00)$ & $(0.00)$ & $(0.00)$ \\
Wyoming & $-0.00^{* * *}$ & $-0.00^{*}$ & 0.00 & $-0.00^{*}$ \\
& $(0.00)$ & $(0.00)$ & $(0.00)$ & $(0.00)$ \\
& $-0.00^{* *}$ & -0.00 & 0.00 & -0.00 \\
& $(0.00)$ & $(0.00)$ & $(0.00)$ & $(0.00)$ \\
& -0.00 & 0.00 & 0.00 & 0.00 \\
& $(0.00)$ & $(0.01)$ & $(0.00)$ & $(0.00)$ \\
\hline
\end{tabular}

Robust standard errors in parentheses

*** $\mathrm{p}<0.01, * * \mathrm{p}<0.05,{ }^{*} \mathrm{p}<0.1$ 


\section{REFERENCES}

Abreu, M., H. De Groot, and R. Florax. 2004. “Space and Growth.” Région et Développement 21:13-40.

Acs, Z. and C. Armington. 2004. "Employment growth and entrepreneurial activity in cities." Regional Studies 38: 911-927

Barro, R. J. 1998. Determinants of Economic Growth: A Cross-Country Empirical Study. MIT Press: Cambridge, MA.

Barro, R. J., and X. Sala-i-Martin. 1992. “Convergence.” Journal of Political Economy 100:223251.

Bates, T., Lofstrom, M., \& Servnon, L. 2010. "Why Have Lending Programs Targeting Disadvantaged Small-Business Borrowers Achieved So Little Success in the United States?” Forschungsinstitut zur Zukunft der Arbeit Institute for the Study of Labor.

Borjas, G. J. 1990. "Friends or strangers: the impact of immigrants on the US economy.” Basic Books, New York, New York.

Borjas, G. J., 2006. "Native internal migration and the labor market impact of immigration.” Journal of Human Resources, 41(2), pp.221-258.

Card, D. and J. DiNardo, 2000. "Do immigrant inflows lead to native outflows?.” The American Economic Review, 90(2), p.360.

Cavalluzzo, K., and J. Wolken. 2005. "Small business loan turn-downs, personal wealth and discrimination.” Journal of Business 78:2153-2178.

Crowder, K., Hall, M. and Tolnay, S.E., 2011. "Neighborhood immigration and native outmigration.” American Sociological Review, 76(1), pp.25-47.

Davis, S.J., J. Haltiwanger, R.S. Jarmin, C. Krizan, J. Miranda, A. Nucci, and K. Sandusky. 2007. "Measuring the dynamics of young and small businesses: Integrating the employer and nonemployer universes.” National Bureau of Economic Research.

Fairlie R., and A. Robb. 2008. Race and entrepreneurial success. Cambridge: MIT Press. Greene, W. 2000. Econometric analysis. Prentice-Hall, New Jersey.

Grey, M., 2006. “Obstacles and opportunities: Latino-owned small businesses in Iowa.” Journal of Latino/Latin American Studies, 2(1), pp.1-23. 
Haltiwanger, J. C., R. S. Jarmin, and J. Miranda. 2010. "Who creates jobs? Small vs. large vs. young." National Bureau of Economic Research.

Hoynes, H. W., M. E. Page, and A. H. Stevens. "Poverty in America: Trends and explanations.” The Journal of Economic Perspectives (2006): 47-68.

Levine, R., N. Loayza, and T. Beck. 2000. "Financial intermediation and growth: Causality and causes.” Journal of Monetary Economics 46(1):31-78.

LeSage, J.P., and M. M. Fischer. 2008. "Spatial growth regressions: model specification, estimation and interpretation.” Spatial Economic Analysis 3(3):275-304.

Mar, D. 2005. "Individual characteristics vs. city structural characteristics: explaining selfemployment differences among Chinese, Japanese, and Filipinos in the United States.” Journal of Socio-Economics 34: 341-359.

Martinez, R. O., B. Avila, O. Santiago, and J. T. Buntin. 2011. "Latino Owned Businesses: Startup Fund Sources and Implications in Comparison to Other Racial/Ethnic Groups." Research Report No. 48, Julian Samora Research Institute, September.

Massey, D. S., J. Arango, G. Hugo, A. Kouaouci, A. Pellegrino, and J. E. Taylor. 1993. "Theories of international migration: a review and appraisal." Population and development review. 431-466.

Puryear, A. N., E. G. Rogoff, M. S. Lee, R. K. Heck, E. B. Grossman, G. W. Haynes, and J. Onochie. 2008. "Sampling minority business owners and their families: The understudied entrepreneurial experience.” Journal of Small Business Management, 46(3), 422-455.

Rey, S. J. and M. V. Janikas. 2005. “Regional Convergence, Inequality, and Space.” Journal of Economic Geography 5:155-176.

Rey S. J., and B. D. Montouri. 1999. "U.S. Regional Income Convergence: A Spatial Econometric Perspective.” Regional Studies 33: 143-156.

Robles, B. J., and H. Cordero-Guzmán. 2007. "Latino Self-Employment and Entrepreneurship in the United States: An Overview of the Literature and Data Sources.” Annals of the American Academy of Political and Social Science 613:18-31.

Robles, B.J. and J. Zarnikau, 2004. Emergent entrepreneurs: Latina-owned businesses in the borderlands.

Rupasingha, A., S. J. Goetz, and D. Freshwater. 2002. "Social and Institutional Factors as Determinants of Economic Growth: Evidence from the United States Counties.” Papers in Regional Science 81:139-155. 
U.S. Census Bureau. 2010. "Survey of Business Owners - Hispanic-Owned Firms: 2007.” Retrieved from http://www.census.gov/econ/sbo/get07sof.html?11.

Zarrugh, L., 2007. From workers to owners: Latino entrepreneurs in Harrisonburg, Virginia. Human organization, 66(3), pp.240-248.

Zhou, M. 2004. "Revisiting ethnic entrepreneurship: convergencies, controversies, and conceptual Advancements.” International migration review, 38(3), pp.1040-1074.

Zong, J. and J. Batalova. 2015. "Frequently Requested Statistics on Immigrants and Immigration in the United States.” Migration Policy Institute, February. Retrieved from: http://www.migrationpolicy.org/article/frequently-requested-statistics-immigrants-andimmigration-united-states. 